\title{
A INDÚSTRIA DE BENEFICIAMENTO DE TILÁPIAS-DO-NILO NO ESTADO DO PARANÁ:UM ESTUDO DE SUA ORGANIZAÇÃO INDUSTRIAL
}

\author{
DENISE RISSATO \\ Economista
}

Orientador: Prof. Dr. PEDRO VALENTIM MARQUES

Dissertação apresentada à Escola Superior de Agricultura "Luiz de Queiroz", Universidade de São Paulo, para obtenção do título de Mestre em Ciências, Área de Concentração: Economia Aplicada.

PIRACICABA

Estado de São Paulo - Brasil

Outubro - 2001 
Dados Internacionais de Catalogação na Publicação (CIP) DIVISÃO DE BIBLIOTECA E DOCUMENTAÇÃO - ESALQ/USP

\author{
Rissato, Denise \\ A indústria de beneficiamento de Tilápias-do-Nilo no Estado do Paraná : um \\ estudo de sua organização industrial / Denise Rissato. - - Piracicaba, 2001. \\ $136 \mathrm{p}$. \\ Dissertação (mestrado) - - Escola Superior de Agricultura Luiz de Queiroz, 2001. \\ Bibliografia. \\ 1. Beneficiamento 2. Comercialização agrícola 3. Indústria pesqueira 4. Mercado \\ 5. Organização industrial 7. Tilápia-do-Nilo I. Título
}

CDD 338.372 


\section{DEDICO}

Aos meus pais Ana e Francisco que, com seu amor incondicional, me apoiaram em todas as conquistas e dificuldades da vida. 


\section{AGRADECIMENTOS}

Ao Professor Pedro Valentim Marques sou especialmente grata pela orientação e dedicação dispensadas no decorrer deste trabalho.

Aos professores Marcos S. Jank e Zilda Paes de Barros Mattos do Departamento de Economia, Administração e Sociologia da Escola Superior de Agricultura "Luiz de Queiroz" e ao professor Ricardo Silveira Martins da Universidade Estadual do Oeste do Paraná pelas valiosas contribuições para a realização deste trabalho.

A todos os professores do Departamento de Economia e Sociologia Rural da Escola Superior de Agricultura "Luiz de Queiroz" por me proporcionarem a oportunidade de aprendizado. Em especial, aos professores Geraldo Sant'ana de Camargo Barros, Paulo Fernando de Araújo Cidade e a Angela Maria C. J. Corrêa, pelo exemplo profissional e pelo incentivo.

Aos todos os funcionários do Departamento de Economia e Sociologia Rural da Escola Superior de Agricultura "Luiz de Queiroz", à Luciane, à Helena, à Maielli, ao Pedro, ao Fernando, à Cristiane, à Ligiana, ao Álvaro e à Márcia que sempre me atenderam com simpatia, profissionalismo e prontidão.

Ao Conselho Nacional de Desenvolvimento Científico e Tecnológico (CNPq), pelo auxílio financeiro recebido.

Aos amigos Carlos Magno Mendes, Patrícia Lima, Cinthia Cabral da Costa, Francisco Casimiro Filho, Sílvia Lima e Carla Regina F. Freire pela amizade e pelo companheirismo. À Maria da Piedade Araújo pelas palavras amigas e pela inestimável ajuda nas horas mais difíceis. A todas as pessoas que de uma forma ou de outra estiveram ao meu lado dando-me força para continuar esta caminhada. 


\section{SUMÁRIO}

\section{Página}

LISTA DE FIGURAS....................................................................................... vii

LISTA DE QUADROS..................................................................................... viii

LISTA DE TABELAS.......................................................................................... ix

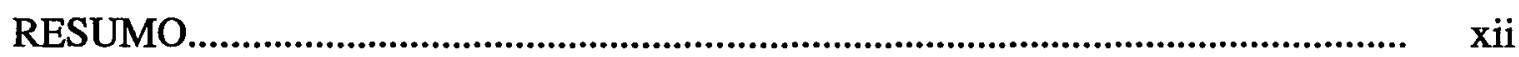

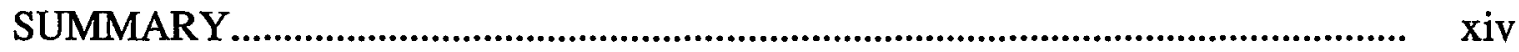

1 INTRODUÇÃO..............................................................................................

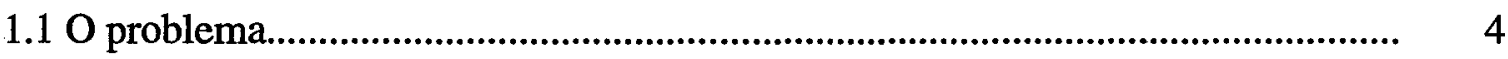

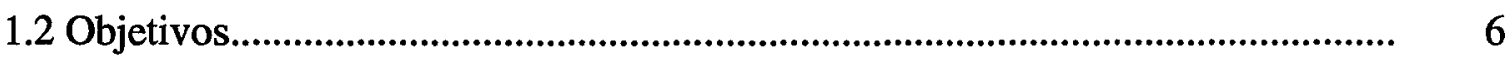

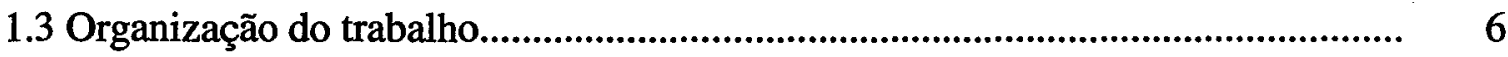

2 A SITUAÇÃO ATUAL DA AQÜICULTURA BRASILEIRA E

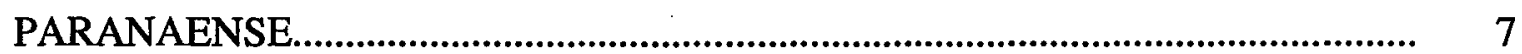

2.1 A atividade pesqueira no Brasil....................................................................... 7

2.2 A produção de pescado no Brasil: pesca versus aqüicultura .................................. 13

2.3 A aqüicultura no Estado do Paraná....................................................................... 25

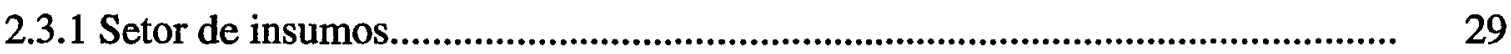

2.3.2 Setor produtivo.................................................................................... 33

2.3.3 Setor de processamento e/ou beneficiamento....................................................... 40

2.3.4 Setor de distribuição e mercado consumidor......................................................... 40

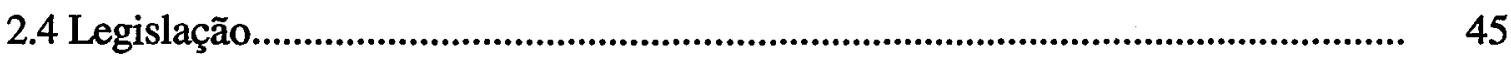

3 REVISÃO DE LITERATURA 
3.1 O paradigma estrutura-conduta-desempenho..................................................... 48

3.2 As estruturas de mercado............................................................................ 51

3.3 A estrutura de mercado e a conduta das empresas.................................................. 55

4 METODOLOGIA...................................................................................... 57

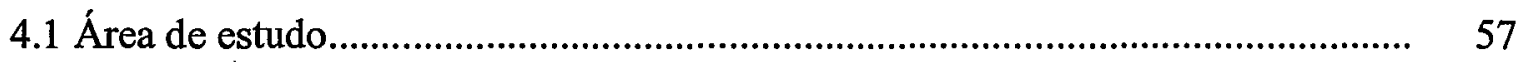

4.1 Fonte e natureza dos dados............................................................................... 58

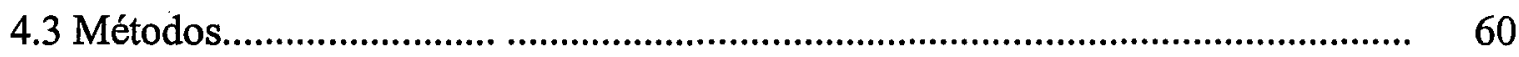

5 RESULTADOS E DISCUSSÃO....................................................................... 71

5.1 A organização da indústria de beneficiamento de tilápias-do-nilo do Estado do

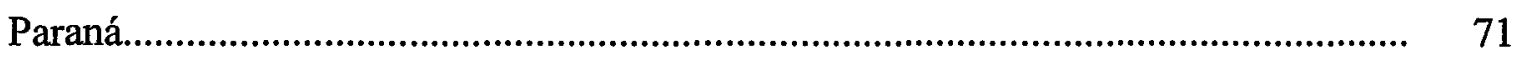

5.1.1 Condições básicas de oferta...................................................................... 72

5.1.2 Condições básicas da demanda........................................................................... 78

5.1.3 Políticas governamentais.......................................................................... 84

5.1.4 Aspectos estruturais da indústria de beneficiamento de tilápia-do-nilo instalada no Estado do Paraná................................................................................. 86

5.2 A conduta da indústria paranaense de beneficiamento de tilápia-do-nilo............. 96

5.2.1 Critério para determinação dos preços do filé de tilápia pelas empresas

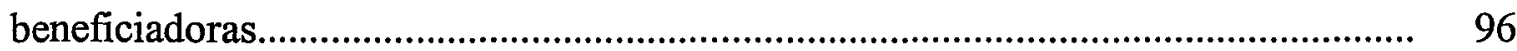

5.2.2 Acordos, contratos e fusões na indústria paranaense de beneficiamento de

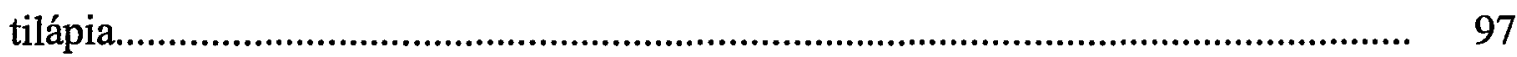

5.2.3 Estratégias de ação das empresas em relação aos concorrentes.......................... 99

5.2.4 Informações sobre o mercado concorrente......................................................... 102

5.2.5 Estratégias de distribuição e vendas............................................................. 103

5.3 Desempenho da indústria paranaense de beneficiamento de tilápia-do-nilo........ 105

5.3.1 Evolução dos preços praticados pela indústria na venda do filé de tilápia........ 105

5.3.2 Evolução da produção e da produtividade............................................................ 111

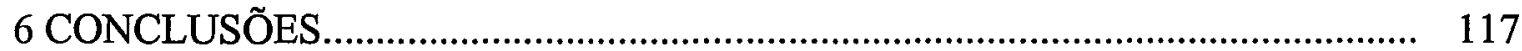

REFERÊNCIAS BIBLIOGRÁFICAS.......................................................... 125

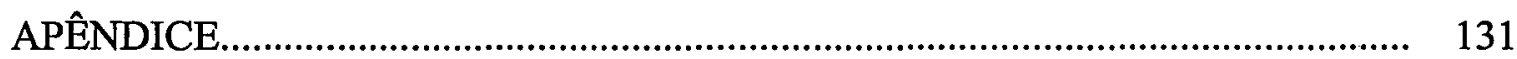




\section{LISTA DE FIGURAS}

Página

1 Produtividade média estadual e regional no período de 1997 a $1999 . . . . . . . . . . . . . . . . .35$

2 Evolução da lâmina d'água destinada à piscicultura no Paraná e nas regiões Oeste e Sudoeste do Estado no período de 1995 a 1999..................................... 38

3 Rendimento industrial da tilápia viva na agroindústria do Estado do Paraná.... 66

4 Participação relativa da indústria e dos produtores artesanais na produção total de filé de tilápia no Estado do Paraná em 1999........................................... 74

5 Evolução dos preços do filé de tilápia no período de set/1995 a set/2000......... 106

6 Margem absoluta do atacadista na comercialização do filé de tilápia no período de setembro/1995 a setembro/2000 ......................................................... 108

7 Margem relativa do atacadista na comercialização do filé de tilápia no período de setembro/1995 a setembro/2000....................................................... 109

8 Evolução da participação do produtor no preço de atacado do filé de tilápia, com aproveitamento dos subprodutos e sem aproveitamento dos subprodutos, no período de setembro/1995 e setembro/2000............................................ 110

9 Evolução da produção industrial de filé de tilápia no período de 1995 a 2000.. 112 


\section{LISTA DE QUADROS}

Página

1 Estruturas de mercado baseadas no número de vendedores e na natureza do produto segundo Scherer (1970).................................................................... 52

2 Estruturas de mercado baseadas no número de vendedores e compradores e nas barreiras à entrada segundo Carlton \& Perloff (1991).................................... 53

3 Tipos de indústria baseados na competição via preço e na competição por diferenciação do produto segundo Guimarães (1981),........................................ 54 


\section{LISTA DE TABELAS}

Página

1 Percentual da produção estadual de tilápias comercializada junto às unidades de beneficiamento nos anos de 1997 e 1999.

2 Participação relativa da pesca extrativa marítima e em água doce e da aquiicultura na produção nacional de pescado no período de 1960 1998.

3 Estimativa do número de aqüicultores e produção da aqüicultura para consumo por região em 1995 e 1998.

4 Faturamento bruto de diversos setores da cadeia produtiva da piscicultura paranaense em 1997.

5 Estimativa da mão-de-obra ocupada pela piscicultura paranaense em diversos setores em 1997.

6 Número de produtores de alevinos e quantidade comercializada nas safras 96/97 e 97/98 no Estado do Paraná..

7 Participação relativa das despesas com os principais insumos e fatores de produção nos custos totais de produção de tilápias no Estado do Paraná............

8 Evolução da produção da piscicultura no Estado do Paraná no período de 1997 a 1999.

9 Evolução na área (ha) de lâmina d'água para piscicultura no Paraná no período de 1995 a 1999.

10 Evolução do número de piscicultores no Estado do Paraná no período de 1995 a 1999. 
11 Número de pesque-pagues e a quantidade de peixe comercializada no Paraná

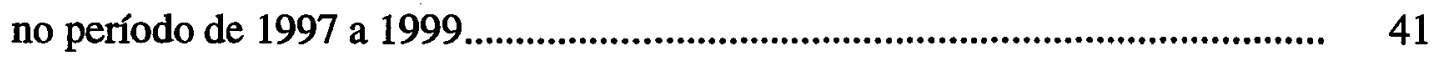

12 Principais canais de comercialização de pescado produzido em cativeiro no Estado do Paraná nos anos de 1997 e 1999

13 Margens de comercialização do atacadista para o filé de tilápia no Estado do Paraná.

14 Produção de filé de tilápia no Estado do Paraná em 1999.

15 Evolução da quantidade de filé vendida pela indústria de beneficiamento de tilápia-do-nilo instalada na região Oeste do Paraná no período de 1995 a 1999

16 Elasticidade-renda da despesa com carnes e pescado no período de 1995 a 1996.

17 Consumo de filé de tilápia no Estado do Paraná em 1999.

18 Fluxo de filé de tilápia no Estado do Paraná em 1999.

19 Número médio de compradores de filé de tilápia, por empresa, no ano de 2000 .

20 Classificação das principais barreiras à entrada de novas empresas na indústria de beneficiamento de tilápias segundo empresários entrevistados......

21 Classificação das principais barreiras à entrada de novas empresas na indústria de beneficiamento de tilápias segundo categorias de empresas...........

22 Resultados do Índice de Herfindahl-Hirschman (HHI) e das parcela de mercado (CR8, CR4 e CR2) para o Estado do Paraná, tomando a produção anual de filé de tilápia de cada empresa no ano de 1999.

23 Formas de fixação de preço do filé na indústria de beneficiamento de tilápia do Estado do Paraná.

24 Porcentagem de empresas da indústria paranaense de beneficiamento de tilápias-do-nilo que adotam estratégias de concorrência e frequiência com que são adotadas. 
25 Informação sobre os concorrentes no mercado de filé de tilápia.......................... 102

26 Formas de comercialização do filé de tilápia.................................................... 104

27 Evolução da produção industrial de filé de tilápia no período de 1995 -

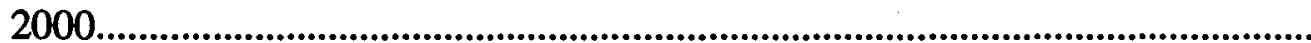

28 Porcentagem de capacidade ociosa média para indústria no período de 1995 a 2000 . 114

29 Razão produção/empregado nos anos de 1999 e 2000. 


\section{A INDÚSTRIA DE BENEFICIAMENTO DE TILÁPIA-DO-NILO NO ESTADO DO PARANÁ: UM ESTUDO DE SUA ORGANIZAÇÃO INDUSTRIAL}

Autor: DENISE RISSATO

Orientador: Prof. Dr. PEDRO VALENTIM MARQUES

\section{RESUMO}

O objetivo deste trabalho foi estudar a organização da indústria de beneficiamento de tilápias-do-nilo criadas em cativeiro no Estado do Paraná, destacando-se aspectos de sua estrutura, conduta e desempenho. Para a sua realização foi utilizado o paradigma estrutura-conduta-desempenho da Organização Industrial. Os dados foram obtidos via entrevista e via telefone junto aos proprietários de todas as unidades de beneficiamento de tilápia, situadas no Paraná, e que, em 2000, estavam autorizadas, pelo Serviço de Inspeção Sanitária e Industrial dos municípios, do Estado do Paraná ou do Ministério da Agricultura, a beneficiar e comercializar pescados e derivados no mercado paranaense. Quanto aos aspectos da estrutura da referida indústria, constatou-se que ela apresenta uma concentração moderada-baixa, com a presença de muitas empresas produtoras, muitos compradores e algumas barreiras à entrada de novas empresas. No entanto, quando analisou-se a concentração nos mercados regionais, verificou-se diferentes graus de concentração, ou seja, moderada- 
alta nas regiões Oeste e Sudoeste, moderada-baixa na região Norte e alta nas regiões Noroeste e Sul. Constatou-se ainda que o acesso à matéria-prima e as dificuldades na comercialização decorrem da estrutura de governança adotada pelas empresas em que as transações com fornecedores e distribuidores ocorrem via de mercado. Com relação à formação de preços, observa-se que a maioria das empresas toma o preço dos seus produtos no mercado. Além disso, as firmas não fazem acordos formais nem estabelecem contratos para aumentar o seu poder de mercado e gastam relativamente pouco com propaganda e promoções. Em relação ao desempenho da indústria, observouse que os preços reais do filé de tilápia mantiveram-se praticamente estáveis, apresentando uma leve tendência de queda no período analisado. No que diz respeito às margens de comercialização do atacadista constatou-se que oscilaram bastante, revelando um comportamento decrescente. Conclui-se que a estrutura atomizada e pouco concentrada deste mercado, aliada à conduta pouco agressiva das empresas explica a tendência de queda nos preços e nas margens absolutas de comercialização do filé, a baixa produtividade e a elevada capacidade ociosa que comprometem não apenas a sustentabilidade da indústria de beneficiamento como também dos demais setores da cadeia produtiva. Ao finalizar este estudo conclui-se que é imprescindível que as empresas discutam e adotem medidas que visem melhorar a qualidade e reduzir o preço dos insumos, que viabilizem o aproveitamento da carcaça e da pele de peixe, resolvendo um problema ambiental e melhorando seu desempenho e que lhe permitam coordenar a produção de matéria-prima e a distribuição do produto final, aumentando a eficiência e a competitividade ao longo da cadeia produtiva da piscicultura. 


\section{THE PROCESSED INDUSTRY OF THE NILE TILAPIA IN THE STATE OF PARANÁ: A STUDY OF ITS INDUSTRIAL ORGANIZATION}

Author: DENISE RISSATO

Adviser: Prof. Dr. PEDRO VALENTIM MARQUES

\section{SUMMARY}

The aim of this paper is to study the industrial organization of the processed industry of the Nile tilapias raised in the state of Paraná , focusing on its structure, conduct and performance. In order to accomplish this work, the Industrial Organization paradigm - structure-conduct-performance was used. The data used were obtained through interviews and telephone calls to the owners of all the fish raising units in the state of Paraná, which, in the year 2000, were authorized by the Sanitary and Industrial Inspection Service of cities in the Parana state or the Ministry of Agriculture, to supply and commercialize fish and derivatives in the "paranaense" market. As for the structural aspects of the aforementioned industry, it was evidenced that it shows a moderate-low concentration with the presence of a good deal of producing enterprises, many purchasers and a few restrictions for the coming of new enterprises. However, when the concentration of the regional markets was analyzed, it was evidenced different degrees of concentration, which is, moderate - high in the Western and Southwestern regions, 
moderate - low in the Northern region and high in the Northern and Southern regions. It was also evidenced that the access to raw material and difficulties in the commercialization resulted from the managing structure adopted by enterprises whose transactions with suppliers and distributors happen via market. As for the prices practices, it is noticed that most of the enterprises quote their products in the market. Moreover, neither do companies have formal agreements nor establish aims to increase their market share. Relatively little is spent in adverting and promotions. As for industrial performance, it was evidenced that the real prices of the fillet of tilapias remained practically stable, with a slight tendency to decrease over the period of analysis. As for the commercialization margins in wholesale, it was noticed that they vary considerably revealing a decreasing behavior. It is concluded that the atomized structure, little concentrated in this market, allied to the little aggressive enterprises conduct, explain the tendency of decrease in prices and in the absolute margins of the fillet commercialization, the low productivity and the high idleness which jeopardize not only the industrial sustainability as well as other sectors of the productive chain. Finalizing this study, it is concluded that it is of vital importance that enterprises discuss and adopt procedures aiming to improve quality and reduce inseam prices which make the use of fish carcass and skin feasible, solving one environmental problem and improving its performance and that allows it to coordinate raw material production and the distribution of final product, increasing efficiency and competition along the chain production of fish. 


\section{INTRODUÇÃo}

O presente estudo analisa a organização da indústria paranaense de beneficiamento de tilápia-do-nilo cultivada, caracterizando seus aspectos de estrutura, conduta e desempenho.

A atividade pesqueira pode ocorrer em águas marítimas, águas estuarinas (junção de água doce com água salgada) e em água doce; e a exploração dos recursos pesqueiros ocorre através da pesca extrativa e dos cultivos. Apesar da inegável ligação entre aqüicultura ${ }^{1}$ e a pesca, pois a aqüicultura se desenvolveu à sombra da atividade pesqueira e ambas destinam-se ao mesmo fim, cabe ressaltar, que a pesca e a aqüicultura são duas atividades econômicas distintas e que apresentam características próprias que as enquadram em contextos produtivos diferenciados. Enquanto a pesca consiste na extração de produtos pesqueiros dos ambientes naturais renováveis, a aqüicultura é a produção propriamente dita de peixes, frutos do mar e de plantas aquáticas.

A aquiicultura mundial está crescendo mais rápido do que qualquer outra atividade do setor primário. Esse crescimento é baseado na percepção de que o ambiente aquático é o um grande sistema de produção, ainda sub-utilizado, cuja exploração tem sido estimulada pelo aumento da população global e pela crescente demanda por alimentos (Takashima \& Strussmann, 1997). Além disso, os programas de saúde, as exigências e o sedentarismo compulsório da vida moderna têm requerido mudanças no hábito alimentar dos consumidores, que vêm substituindo de forma gradativa e crescente as carnes vermelhas por pescado, principalmente em países mais desenvolvidos (Cyrino \& Grÿschek, 1997).

\footnotetext{
${ }^{1}$ Aqüicultura é o cultivo de animais e plantas aquáticas. Como exemplo, temos a piscicultura que é uma ramo da aqüicultura e compreende o cultivo de peixes.
} 
Em 1990, a demanda mundial de pescado foi de cerca de 95 milhões de toneladas, atendida com, aproximadamente, 80 milhões de toneladas de pescado proveniente da captura e cerca de 15 milhão de toneladas obtidas em cultivos. Para o ano de 2025, estima-se uma demanda global de 160 milhões de toneladas. Considerando-se o problema da sobrepesca e supondo ser possível manter a oferta de pescado capturado mediante a administração dos estoques naturais, conclui-se que seriam necessárias aproximadamente 80 milhões de toneladas de pescado cultivado para suprir a demanda global estimada (Hopkins \& Manci, 1993).

Estudos realizados por Ostrenski et al (2000) mostram que em 1994, a produção da aqüicultura mundial foi de 27,7 milhões de toneladas avaliadas em US\$ 39,53 bilhões de dólares, indicando um aumento de $13 \%$ na quantidade produzida e de 13,3\% em valor, em relação ao ano anterior. Segundo dados da FAO (1998), em 1997, a produção aqüícola, incluindo as plantas aquáticas, contribuiu com mais de 36 milhões de toneladas, gerando uma receita de US\$ 49 bilhões. Desta forma, confirma-se a tendência de que, segundo a FAO (1994), se a aquicultura continuar mantendo a taxa média anual de crescimento da última década, entre 10 e $15 \%$ a.a., em 2010, a produção mundial do setor deverá ultrapassar 40 milhões de toneladas de pescados.

De acordo com Ostrenski et al (2000), é possível prever que, por um longo tempo, a China ditará as tendências da produção aqüícola mundial. A China é a maior produtora mundial, respondendo por $66,7 \%$ da produção e por $48 \%$ da receita mundial. A produção chinesa apresentou uma taxa de crescimento de $12,9 \%$ a.a. no período de 1984 a 1990 e de 19,5\% a.a. entre 1990 e 1996. Outros grandes produtores da aquiicultura mundial como a Índia, a Tailândia, Bangladesh e a Noruega vêm apresentando taxas de crescimento da produção superiores a $8 \%$ a.a. O continente europeu responde por $4,6 \%$ da produção mundial, seguida da América do Norte e América do Sul que juntas produzem $3,6 \%$ da produção global.

Apesar do Brasil possuir um grande potencial hídrico e uma das mais ricas ictiofaunas do mundo, somente a partir da década de 80 , é que surgem as primeiras iniciativas de exploração comercial da aqüicultura. 
Segundo Abdallah (1998), no período de 1960 a 1994, 78\% da produção total média de pescado no Brasil foi proveniente da pesca marítima, enquanto a produção oriunda das águas interiores representou o equivalente a $22 \%$ da produção média brasileira. No período de 1972 a 1974, de acordo com Abdallah (1998), a produção de pescado de água doce representou, respectivamente, apenas $13,7 \%, 12,6 \%$ e $15,4 \%$, da produção brasileira total de pescado. Já no período de 1990 a 1994, essa participação cresceu para, aproximadamente, $30 \%$.

Esse crescimento da participação percentual da produção de pescado de água doce na produção total de pescado brasileiro se deve tanto à redução dos estoques pesqueiros naturais ameaçados pela sobrepesca, pela captura predatória e pela degradação dos locais de pesca em decorrência da expansão imobiliária e do turismo nas regiões litorâneas quanto pela expansão da piscicultura a partir da década de 90 , nos estados do Paraná, Santa Catarina, Rio Grande do Sul, São Paulo e Minas Gerais.

A Região Sul do Brasil lidera a produção aquuícola nacional, sendo os Estados do Paraná e Santa Catarina os maiores produtores de pescados cultivados. Santa Catarina destaca-se como uma grande produtora de moluscos, peixes e crustáceos cultivados enquanto o Estado do Paraná dedica-se à produção de pescado de água doce em cativeiro, principalmente tilápias (Workshop para subsidiar a capacitação de recursos humanos e a geração de tecnologia em aqüicultura sustentável apud Abdallah, 1998).

No Paraná, principalmente na região Oeste do Estado, a piscicultura comercial começou a ser praticada a partir da segunda metade da década de 80 estimulada por vários fatores, entre os quais pode-se destacar o programa de manejo e conservação de solos desenvolvido pela Secretaria de Estado da Agricultura em convênio com a Empresa de Assistência Técnica e Extensão Rural - EMATER-Paraná e com a Companhia de Desenvolvimento Agropecuário do Paraná - CODAPAR que permitiu conter o assoreamento dos rios, a degradação dos solos e melhorar a qualidade das águas existentes; destaque-se, ainda, o crédito subsidiado fornecido aos piscicultores pelo governo de Estado, além da necessidade de diversificar a produção nas propriedades rurais como forma de complementar a renda dos pequenos produtores (Rissato, 1995). 


\subsection{O Problema}

No início da década de 80 , a incipiente estrutura de comercialização da produção de pescado constituía-se em um dos principais entraves ao desenvolvimento da piscicultura estadual. Dez anos depois, de acordo com uma pesquisa realizada em 1992, a falta de estrutura de comercialização ainda era apontada como um dos principais problemas enfrentados pelos piscicultores da região Oeste paranaense (Rissato, 1995).

É neste contexto que surgem, no início da década de 90, as primeiras unidades de beneficiamento ${ }^{2}$ e distribuição de tilápia-do-nilo produzida $\mathrm{em}$ cativeiro, com o intuito de organizar a produção e a distribuição do peixe produzido na região. Além disso, a indústria surge, para os piscicultores, como uma garantia de comercialização do seu produto durante todo o ano, já que, até então, o peixe era comercializado apenas em feiras, nas residências ou na propriedade rural em pequenas quantidades e apenas em algumas épocas do ano, como por exemplo, na quaresma.

Nas outras regiões do Estado, a piscicultura passou a ser praticada em escala comercial somente a partir de meados da década de 90 motivada pela intensa e crescente demanda de peixe vivo por parte dos pesque-pagues instalados nos Estados do Paraná, São Paulo e Minas Gerais. Posteriormente, devido ao funcionamento sazonal desses estabelecimentos (apenas durante o verão) também foram instaladas unidades de beneficiamento de pescado nessas regiões como forma de absorver a produção excedente de pescado. Contudo, cabe destacar que, enquanto na região Oeste, desde o princípio, a atividade esteve direcionada para a indústria, nas outras regiões do Estado a piscicultura desenvolveu-se voltada para o mercado dos pesque-pagues.

Essa situação é confirmada pelos dados publicados pela EMATER-Paraná sobre o percentual da produção paranaense de tilápias que foi comercializado junto às unidades de beneficiamento durante os anos de 1997 e 1999. Constata-se que, a região Oeste do estado foi a que mais comercializou junto à indústria de beneficiamento de

\footnotetext{
2 Como empresas normalmente apenas filetam o peixe, e não o submetem a nenhum tipo de processamento, são denominadas unidades de beneficiamento e não processadoras.
} 
tilápias nos anos de 1997 e 1999, enquanto as demais regiões do estado produziram parcelas bem menores destinadas à indústria, conforme Tabela 1 .

Tabela 1. Percentual da produção estadual de tilápias comercializada junto às unidades de beneficiamento nos anos de 1997 e 1999.

\begin{tabular}{lcc}
\hline & 1997 & 1999 \\
\hline Região Oeste & $39 \%$ & $33 \%$ \\
Região Sudoeste & $29 \%$ & $21 \%$ \\
Região Norte & $2,7 \%$ & $0,6 \%$ \\
Região Noroeste & - & $6 \%$ \\
\hline
\end{tabular}

Fonte: EMATER-Paraná, 1999.

Essa redução do volume de pescado comercializado junto à indústria se deve ao aumento da participação dos pesque-pagues enquanto compradores do peixe cultivado no Paraná, inclusive a tilápia-do-nilo que é a principal matéria-prima da referida indústria.

Apesar da queda na participação da indústria, estes dados revelam o importante papel desempenhado pela indústria de beneficiamento na comercialização do pescado produzido, especialmente, em algumas regiões do Estado do Paraná.

Além disso, de acordo com Valle \& Proença (2000), as tilápias deverão ser a espécie de peixe mais explorada pela aqüicultura brasileira, sendo oferecidas no mercado interno e externo, em forma de filés ou de outros produtos processados. Por todos esses fatores, considera-se de grande importância estudar a organização deste elo da cadeia produtiva da piscicultura paranaense que é a indústria de beneficiamento de tilápias-do-nilo. 


\subsection{Objetivos}

O presente estudo analisa a organização da indústria paranaense de beneficiamento de tilápia-do-nilo cultivada, caracterizando seus aspectos de estrutura, conduta e desempenho.

Especificamente, pretende-se:

a) Procurar saber quais são as características da organização do mercado, sua influência sobre a natureza da competição e sobre a formação dos preços;

b) Verificar qual o tipo de conduta das unidades de beneficiamento de pescado bem como, as condições básicas de oferta e demanda, as políticas governamentais e a estrutura do mercado podem afetar e como podem ser afetadas por esta conduta das empresas;

c) Avaliar o desempenho da referida indústria a partir de alguns dos seus resultados econômicos, tais como a evolução dos preços praticados, a participação do produtor no preço da indústria, o comportamento das margens de comercialização da indústria, a capacidade ociosa da indústria e a evolução da produção e da sua produtividade.

\subsection{Organização do trabalho}

Além desta introdução, esta dissertação consta de mais 5 capítulos. O capítulo 2 descreve a evolução e a situação atual da aqüicultura no Brasil e no Estado do Paraná. Nos capítulos 3 e 4 são apresentados o referencial teórico-metodológico. No capítulo 5 , são expostas as análises de aspectos da estrutura, conduta e desempenho da indústria paranaense de beneficiamento de tilápia-do-nilo. Finalmente, com as informações dos capítulos anteriores, no capítulo 6, são apresentadas as conclusões da dissertação. 


\section{A SITUAÇÃO ATUAL DA AQÜICULTURA BRASILEIRA E PARANAENSE}

O presente capítulo analisa a evolução e a atual situação da aqüicultura no Brasil e no Estado do Paraná. Para proceder à análise, no item 2.1 apresenta-se uma síntese das políticas pesqueiras federais tanto no que diz respeito à regulamentação quanto aos incentivos fiscais concedidos ao setor pesqueiro no Brasil, com o intuito de situar, no tempo, as iniciativas públicas no sentido de regulamentar as atividades do setor aqüícola, como forma alternativa de suprir a demanda de pescado não mais atendida pela pesca extrativa. No item 2.2 , procura-se analisar a produção nacional de pescado, considerando sua distribuição geográfica e seu valor, bem como tem evoluído a participação da aqüicultura nesta produção. No item 2.3 descreve-se a evolução da aquiicultura paranaense, identificando os fatores que promoveram o seu desenvolvimento sistemático e organizado, caracterizando-se o perfil atual da cadeia produtiva da piscicultura no Estado. Para concluir este capítulo, apresenta-se, no item 2.4, um resumo da legislação que regulamenta o funcionamento da indústria de beneficiamento de tilápia-do-nilo cultivada no Estado do Paraná.

\subsection{A atividade pesqueira no Brasil}

A atividade pesqueira nacional, quanto a sua evolução, pode ser dividida em duas grandes fases. A primeira fase, chamada de artesanal ou pré-industrial se inicia em meados do século XIX e vai até 1962 , e a segunda, denominada fase industrial, tem 
como marco a criação da Superintendência do Desenvolvimento da Pesca (SUDEPE) em outubro de 1962.

-Primeiro Período - Pré Industrial - Meados do século XIX até 1962

No Brasil, de acordo com Giulietti \& Assumpção (1995), a atividade pesqueira surgiu ainda no período colonial em meados do século XVIII com a pesca de baleias que se destinavam à indústria de óleo. Contudo, até a década de 50, a pesca ainda era uma atividade pré-industrial, não se constituindo, propriamente em uma cadeia produtiva.

No período que vai até 1912, aparecem os primeiros atos legais voltados à regulamentação da atividade pesqueira no Brasil. No entanto, como a pesca não representava uma fonte de riqueza para o Estado, não havia interesse e preocupação em regulamentar a atividade.

Nesse período foram regulamentadas a pesca de baleias e a importação de sal para conservação do pescado, concedidos alvarás autorizando a construção e armação de embarcações para pesca e processamento de pescados, ou seja, foram dados os primeiros passos para a nacionalização da pesca e a efetivação de estudos voltados à atividade na costa brasileira.

Ainda nesse século, teve início o processo de institucionalização da pesca no Brasil, com a criação da Inspetoria da Pesca (em 1912) e a intensificação das ações do Ministério da Marinha no sentido de organizar os pescadores em colônias cooperativas. Esse trabalho representou um primeiro passo na organização da produção pesqueira, embora esta ainda fosse praticamente uma atividade de subsistência.

No período entre 1933 e 1961, as atividades pesqueiras passam a ser geridas pela Divisão de Caça e Pesca, vinculada ao Ministério da Agricultura, que dá continuidade às ações até então desenvolvidas pelo Ministério da Marinha, dando ênfase sobretudo às atividades de promoção social e pesquisa. Segundo Abdallah $(1999, \mathrm{p} .41)$ 
"A Divisão de Caça e Pesca teve papel importante no desenvolvimento da atividade pesqueira no País. Esse órgão investiu em pesquisa ( na área de biologia marinha), em extensão (na formação de técnicos especializados em pesca e qualificação da mão-deobra), em infra-estrutura básica de apoio à atividade pesqueira, no aumento da fiscalização, além de realizar as atividades até então estabelecidas pelos órgãos anteriores".

Cabe ressaltar que, nesse período, as políticas para regulamentar a atividade pesqueira foram estabelecidas praticamente nos anos 30 e na primeira metade da década de 40. O período de 1945 a 1961 foi marcado por uma pulverização de legislações que dificultaram a coordenação da atividade pesqueira no país.

No contexto das políticas desenvolvimentistas e nacionalistas praticadas na década de 30, com a edição do Decreto Lei $\mathrm{N}^{\circ} 291$, de 23/02/38, entrou em vigor a conhecida "Lei da Expansão da Pesca" com o intuito de viabilizar o autofinanciamento da atividade pesqueira nacional através da criação do Caixa de Crédito da Pesca, cujos recursos, segundo Giulietti \& Assumpção (1995), provinham de uma taxa de 5\% cobrada sobre as vendas de pescado nos entrepostos federais e que se destinavam a financiar a aquisição de equipamentos e insumos diversos, bem como a instalação de pequenas indústrias e armazéns.

Em 1961, foi criado o Conselho de Desenvolvimento da Pesca (CODEPE) com atribuições relacionadas à pesquisa, planejamento, formação de recursos humanos, expansão de mercados e assessoramento ao Governo.

- Segundo Período - Fase Industrial - 1962 e 1989

Somente a partir da criação da Superintendência para o Desenvolvimento da Pesca (SUDEPE) em 1962, que tinha como atribuições elaborar e executar o Plano Nacional de Desenvolvimento Pesqueiro, aplicar o Código de Pesca e a legislação das atividades ligadas ao setor pesqueiro e assistir aos pescadores na solução de seus problemas sócio-econômicos, é que a atividade pesqueira passa a ser considerada 
indústria de base podendo, portanto, ser financiada pelo Banco Nacional de Desenvolvimento Econômico (BNDE).

Com a promulgação do Decreto-lei $\mathrm{N}^{\circ} 221 \mathrm{em} 1967$, a pesca passa a fazer parte do rol de atividades importantes para o desenvolvimento do país, podendo, portanto, ser beneficiada por vários incentivos fiscais. A partir de 1968, a SUDEPE passa a gerir também a exploração e a pesquisa na plataforma submarina, nas águas do mar territorial e nas águas interiores do Brasil.

Nesse período, de acordo com Giulietti (1996), a atividade iniciou um processo de desenvolvimento e passou a se organizar como uma cadeia produtiva agroindustrial.

Cabe ressaltar que ao longo desse período, a SUDEPE editou várias portarias regulamentando a exploração racional dos recursos pesqueiros naturais, estipulando cotas de captura, limitando a pesca através do controle dos insumos (tamanho e tipos de redes, tamanho e quantidade de barcos, instrumentos de pesca) e estabelecendo períodos de pesca. Inclusive, de acordo com o Decreto $\mathrm{N}^{\circ} 68.459 / 71$, ficaram previstas penalidades aos infratores, não apenas em pecúnio, mas também nos termos da legislação penal vigente.

Todavia, apesar dos diversos dispositivos legais, a exploração dos recursos pesqueiros naturais não aconteceu de forma planejada e racional. Ainda na década de 80 , já apareciam os primeiros sinais da sobrepesca de algumas espécies.

Percebe-se que, ao longo dos anos, a atividade pesqueira, no Brasil, foi motivo de preocupação e interesse para o setor público, no entanto, apesar dos diversos orgãos criados e dos inúmeros dispositivos legais voltados à atividade pesqueira, os resultados obtidos são considerados apenas satisfatórios.

$\mathrm{Na}$ verdade, a falta de diretrizes e de políticas adequadamente formuladas na área de pesquisa levaram a SUDEPE a uma ação não orientada e nem controlada das pesquisas pesqueiras. Apesar dos incentivos fiscais dados à pesca terem dado grande impulso à industrialização, os objetivos alcançados foram muito distintos dos planejados em decorrência de falta de critérios técnicos, econômicos e sociais na aplicação dos recursos. Segundo Giulietti \& Assumpção (1995), dos recursos aplicados no fomento e desenvolvimento da atividade pesqueira, no período de $1967-72$, cerca de $51 \%$ 
destinaram-se à indústria, $20 \%$ desses foram aplicados no sentido de aumentar os esforços de captura, $13 \%$ na administração, apenas $7 \%$ em comercialização e, em pesquisa e levantamento dos recursos naturais (estoques pesqueiros), nada foi investido.

Esse desequilíbrio na aplicação dos recursos provenientes dos incentivos fiscais e o forte estímulo à intensiva exploração dos recursos pesqueiros até a sua quase exaustão foram, provavelmente, as principais causas do insucesso das políticas fiscais direcionadas à pesca.

Em 1986 começam a surgir as primeiras regulamentações voltadas à aqüicultura no Brasil, no sentido de normatizar e controlar o uso das águas para cultivo de organismos aquáticos.

A partir de 1990, com a extinção da SUDEPE, as atribuições relacionadas à pesca passaram a ser desempenhadas pelo Instituto Brasileiro do Meio Ambiente e dos Recursos Naturais Renováveis e da Amazônia Legal (IBAMA), vinculado à Secretaria do Meio Ambiente, a quem compete incentivar a pesquisa, a divulgação, a normatização, o controle e a fiscalização relativas aos recursos naturais renováveis no Brasil.

Cabe ressaltar que, embora nesse período tenham sido criados diversos dispositivos legais, através de portarias do IBAMA, visando ao ordenamento da atividade pesqueira no país, sempre faltou no Brasil uma legislação mais efetiva para punir os infratores e degradadores do meio ambiente.

Nesse contexto, por iniciativa do IBAMA, foi criada a Lei $\mathrm{N}^{\circ} 9605$ de 12/02/1998, também conhecida como a Lei dos Crimes Ambientais, que prevê penas alternativas à prisão para responsáveis. No caso da pesca, essa Lei considera infração pescar em períodos em que a atividade seja proíbida, pescar espécies em extinção ou com tamanhos inferiores e ou quantidades superiores às permitidas, transportar, comercializar, beneficiar ou industrializar produto de procedência proibida. Embora não estabeleça disposições específicas, o Decreto também define infrações e penalidades aplicáveis ao setor aqüícola.

Nesse período também podem ser destacadas outras legislações direcionadas à aqüicultura, tais como: 
- Portaria $\mathrm{N}^{\circ}$ 095, de 03/08/93, que estabelece as regras para o cadastro de aquiicultores junto ao IBAMA, visando obter um banco de dados estatísticos sobre a atividade aqüícola brasileira.

- Decreto $\mathrm{N}^{\circ} 1694 / 95$, voltado para a organização da atividade da pesca e da aqüicultura. Para isso, fica criado o Sistema Nacional de Informações da Pesca e da Aqüicultura, que sob a coordenação da Fundação Instituto Brasileiro de Geografia e Estatística (IBGE) tem o objetivo de levantar, agregar, processar, analisar e divulgar informações sobre a atividade pesqueira nacional.

- Decreto $\mathrm{N}^{\circ} 1695 / 95$, que normatiza a exploração da aqüicultura em águas públicas pertencentes à União, atribuindo ao IBAMA a tarefa de fazer o registro dos aqüicultores, incluindo controle sanitário dos organismos cultivados, das espécies cultivadas, o monitoramento periódico da qualidade das águas na área de influência do empreendimento, bem como a especificação dos equipamentos e técnicas utilizados pelo produtor.

- Portaria No 451 de 19/09/1997, da Secretaria Nacional de Vigilância Sanitária do Ministério da Saúde, que aprova o Regulamento Técnico e Princípios Gerais para o estabelecimento de critérios e padrões microbiológicos para alimentos, inclusive pescados e produtos de pesca. No caso da aqüicultura, esse instrumento legal representa uma garantia de proteção da saúde da população e um maior rigor nas práticas de manejo dos cultivos e produção dos alimentos.

- Portaria N $^{\circ} 113$ de 25/11/1997, do IBAMA, que torna obrigatório o registro de pessoas físicas ou jurídicas no Cadastro Técnico Federal de Atividades Potencialmente Poluidoras ou Utilizadoras de Recursos Naturais, incluindo as seguintes categorias relacionadas à aqüicultura: o aqüicultor, os pesque-pagues e as empresas que comercializam animais aquáticos vivos.

- Portaria No 136 de 14/10/1998 que estabelece as normas para o registro de aqüicultores e pesque-pagues no IBAMA e condiciona o transporte e a comercialização de animais abatidos, oriundos da aqüicultura ou pesque-pagues, ao acompanhamento por documento quando se tratar de espécie nativa que se encontra em período de defeso na 
pesca extrativa e no caso de espécies nativas com tamanho inferior ao estabelecido na legislação vigente.

- Decreto $N^{\circ} 2869$ de 09/12/1998 que revoga o Decreto No1.695 de 13/11/95 definindo áreas, normatizando a exploração da aqüicultura em águas públicas pertencentes à União, e prevendo a ação conjunta do Ministério da Agricultura e do Abastecimento, do Ministério da Marinha, do Ministério da Fazenda, do Ministério do Meio Ambiente e do IBAMA, no sentido de estimular e fortalecer o cooperativismo e ou quaisquer formas associativas dos aqüicultores, fomentar a verticalização, a agregação de valores aos produtos, a organização e o desenvolvimento da cadeia produtiva além de assegurar o acesso dos produtores ao sistema de inspeção industrial e sanitária de produtos de origem pesqueira.

A partir de 1998, verifica-se o envolvimento de vários órgãos e departamentos federais no planejamento, ordenamento, fomento e fiscalização da pesca e da aquiicultura brasileira. É importante destacar que, em julho de 1998, foi criado junto ao Ministério da Agricultura e do Abastecimento, o Departamento de Pesca e Aqüicultura (DPA), não tendo sido extinto o Departamento de Pesca e Aqüicultura (DEPAQ) do IBAMA (Proença \& Oliveira Neto, 2000).

Observa-se nesse período, uma mudança expressiva na política federal brasileira com relação aos recursos naturais, agora muito mais preocupada com a sua sustentação no longo prazo. Verifica-se também interesse e preocupação, nos últimos anos, em dar condições para que a aqüicultura se desenvolva, no país, de forma racional e sustentável.

\subsection{A produção de pescado no Brasil: pesca versus aqüicultura}

A produção de pescado, no Brasil, cresceu no período de 1960 a 1998, passando de 281,5 mil toneladas para 1.108.534 mil toneladas, respectivamente, de acordo com a Tabela 2. 
Tabela 2. Participação relativa da pesca extrativa marinha e em água doce e da aquicultura na produção nacional de pescado no período de 1960-1998.

\begin{tabular}{|c|c|c|c|c|c|c|c|c|}
\hline \multirow[t]{2}{*}{ Ano } & \multirow{2}{*}{$\begin{array}{c}\text { Produção } \\
\text { Total de } \\
\text { Pescado }\end{array}$} & \multicolumn{4}{|c|}{ Produção de Pescado Capturado } & \multicolumn{3}{|c|}{ Produção Aqüícola } \\
\hline & & \multicolumn{2}{|c|}{ Produção Marítima } & \multicolumn{2}{|c|}{ Pesca de Água Doce } & \multirow{2}{*}{$\begin{array}{c}\text { Maricultura } \\
\text { n.d. }\end{array}$} & \multicolumn{2}{|l|}{ Piscicultura } \\
\hline 1960 & 281.512 & 220.705 & 78,4 & 54.895 & 19,5 & & n.d. & n.d. \\
\hline 1961 & 330.140 & 263.452 & 79,8 & 60.416 & 18,3 & n.d. & n.d. & n.d. \\
\hline 1962 & 414.640 & 337.932 & 81,5 & 66.757 & 16,1 & n.d. & n.d. & n.d. \\
\hline 1963 & 421.356 & 339.613 & 80,6 & 78.793 & 18,7 & n.d. & n.d. & n.d. \\
\hline 1964 & 377.008 & 282.002 & 74,8 & 94.629 & 25,1 & n.d. & n.d. & n.d. \\
\hline 1965 & 422.289 & 326.852 & 77,4 & 94.593 & 22,4 & n.d. & n.d. & n.d. \\
\hline 1966 & 435.787 & 351.244 & 80,6 & 84.107 & 19,3 & n.d. & n.d. & n.d. \\
\hline 1967 & 429.422 & 340.532 & $79,3^{*}$ & 88.461 & 20,6 & n.d. & n.d. & n.d. \\
\hline 1968 & 500.387 & 391.303 & 78,2 & 107.083 & 21,4 & n.d. & n.d. & n.d. \\
\hline 1969 & 501.197 & 387.425 & 77,3 & 112.268 & 22,4 & n.d. & n.d. & n.d. \\
\hline 1970 & 526.292 & 422.086 & 80,2 & 103.679 & 19,7 & n.d. & n.d. & n.d. \\
\hline 1971 & 591.543 & 493.347 & 83,4 & 97.605 & 16,5 & n.d. & n.d. & n.d. \\
\hline 1972 & 604.673 & 521.833 & 86,3 & 82.840 & 13,7 & n.d. & n.d. & n.d. \\
\hline 1973 & 698.802 & 610.753 & 87,4 & 88.049 & 12,6 & n.d. & n.d. & n.d. \\
\hline 1974 & 815.720 & 690.099 & 84,6 & 125.621 & 15,4 & n.d. & n.d. & n.d. \\
\hline 1975 & 759.792 & 585.800 & 77,1 & 173.992 & 22,9 & n.d. & n.d. & n.d. \\
\hline 1976 & 658.847 & 513.901 & 78,0 & 144.946 & 22,0 & n.d. & n.d. & n.d. \\
\hline 1977 & 752.607 & 584.023 & 77,6 & 168.584 & 22,4 & n.d. & n.d. & n.d. \\
\hline 1978 & 806.328 & 645.869 & 80,1 & 160.459 & 19,9 & n.d. & n.d. & n.d. \\
\hline 1979 & 858.183 & 731.172 & 85,2 & 127.011 & 14,8 & n.d. & n.d. & n.d. \\
\hline 1980 & 822.677 & 635.929 & 77,3 & 186.748 & 22,7 & n.d. & n.d. & n.d. \\
\hline 1981 & 833.164 & 635.704 & 76,3 & 197.460 & 23,7 & n.d. & n.d. & n.d. \\
\hline 1982 & 833.933 & 627.118 & 75,2 & 206.815 & 24,8 & n.d. & n.d. & n.d. \\
\hline 1983 & 880.969 & 675.703 & 76,7 & 205.266 & 23,3 & n.d. & n.d. & n.d. \\
\hline 1984 & 992.319 & 749.367 & 75,52 & 201.102 & 20,27 & 2.050 & 39.800 & 4,22 \\
\hline 1985 & 995.092 & 751.052 & 75,48 & 200.678 & 20,17 & 3.562 & 39.800 & 4,36 \\
\hline 1986 & 993.590 & 733.398 & 73,81 & 213.164 & 21,45 & 5.478 & 41.550 & 4,73 \\
\hline 1987 & 994.195 & 715.183 & 71,94 & 219.669 & 22,10 & 7.693 & 51.650 & 5,97 \\
\hline 1988 & 885.392 & 623.577 & 70,43 & 190.566 & 21,52 & 11.304 & 59.945 & 7,80 \\
\hline 1989 & 913.928 & 633.734 & 69,34 & 193.290 & 21,15 & 15.704 & 71.200 & 9,51 \\
\hline 1990 & 885.584 & 590.035 & 66,63 & 191.115 & 21,58 & 17.104 & 87.330 & 11,79 \\
\hline 1991 & 868.996 & 573.046 & 65,94 & 193.270 & 22,24 & 17.135 & 85.545 & 11,82 \\
\hline 1992 & 871.964 & 558.976 & 64,11 & 182.773 & 20,96 & 18.615 & 111.600 & 14,93 \\
\hline 1993 & 856.699 & 537.798 & 62,78 & 186.166 & 21,73 & 18.615 & 114.120 & 19,00 \\
\hline 1994 & 910.852 & 540.849 & 59,38 & 235.118 & 25,81 & 18.615 & 116.270 & 14,81 \\
\hline 1995 & 884.221 & 513.892 & 58,12 & 193.414 & 21,87 & 22.207 & 154.708 & 20,01 \\
\hline 1996 & 1.021 .768 & 522.690 & 51,16 & 193.971 & 18,98 & 34.648 & 270.459 & 29,86 \\
\hline 1997 & 1.079 .717 & 565.887 & 52,41 & 186.181 & 17,24 & 38.173 & 289.476 & 30,35 \\
\hline 1998 & 1.108 .534 & 580.140 & 52,33 & 180.245 & 16,26 & 41.003 & 307.146 & 31,41 \\
\hline
\end{tabular}

a ${ }_{\text {n.d.: não disponível }}$

Fonte: Os dados referentes a produção total de pescado para o período 1960 a 1983 foram retirados de Abdallah (1998); os dados referentes ao período de 1984 a 1998 foram extraídos de FAO Fish (2000) 
No entanto, ao longo do período, essa produção apresentou comportamento oscilatório. No período de 1960 a 1962, a produção de pescado cresceu, passando de 281,5 mil toneladas para 414,6 mil toneladas, permanecendo praticamente constante entre os anos de 1963 e 1967.

Durante o período de 1968-85, a produção voltou a crescer, com exceção dos anos 1975, 1976, 1977 e 1980. O aumento da produção de pescado ocorrido no período de 1968-74 pode ser explicado pelos incentivos fiscais concedidos. Segundo Abdallah (1998, p.58), entre 1967 e 1974, foram concedidos $R \$ 793,49$ milhões (em $R \$$ de agosto de 1994) como incentivos fiscais à pesca. De acordo com Neiva (1990), essa política de incentivos permitiu investimentos em um parque industrial moderno para o pescado, a expansão das áreas de pesca e, conseqüentemente, aumentos significativos da produção.

Já, no período de 1975 a 1982, os incentivos fiscais não foram suficientes para estimular aumentos da produção. Enquanto no período 1967-74 foram concedidos incentivos de, em média, $\mathrm{R} \$ 99,19$ milhões por ano, no período de 1975-82 estes foram de aproximadamente, de $\mathbf{R} \$ 23,82$ milhões por ano (Abdallah, 1998).

No início da década de 80 , a política de restrições às importações, inclusive para o pescado, promoveu o grande salto na produção brasileira desses produtos que passou de 833,9 milhões de toneladas em 1982 para 995,09 milhões de toneladas em 1985.

A partir de 1986, a sobrepesca levou à redução dos estoques naturais contribuindo, consequientemente, para a redução da produção que passou a apresentar sucessivos decréscimos até o ano de 1993, voltando a crescer nos anos de 1994, 1996, 1997 e 1998.

Apesar de quase $80 \%$ do território brasileiro estar localizado em região tropical, drenada por duas grandes bacias hidrográficas (Amazônica e do Paraná-Paraguai), onde existem mais de 100 reservatórios e barragens compreendendo aproximadamente 5 milhões de hectares de área alagada (Castagnolli, 1995), sempre foi pequena a participação da águas interiores na produção nacional de pescado capturado e cultivado ( ver a Tabela 2). 
No período de 1960 a 1970, a participação da pesca marítima na produção nacional de pescado representou, em média $80 \%$, enquanto o pescado de água doce respondeu por 20\%. Entre 1971-74, a produção da pesca marítima passou a representar 85\% da produção total e a participação da pesca em águas interiores caiu para, em média, $15 \%$. A partir de 1980, a pesca extrativa marítima começa a responder por parcelas cada vez menores da produção total de pescado brasileira. Já a pesca em água doce, por sua vez, mantém uma participação estável na produção total brasileira, em torno dos 22\%, entrando em declínio a partir de 1995.

De acordo com Abdallah (1998), a participação predominante da pesca de origem marinha está relacionada com o processo histórico de desenvolvimento da atividade pesqueira no Brasil, pois, segundo a mesma autora, tanto as políticas federais de regulamentação quanto as de incentivos fiscais, implementadas nas décadas de 60, 70 e 80, não tiveram significativos efeitos sobre a produção de pescado de água doce, estando quase sempre direcionadas para a pesca marítima.

Analisando a evolução da atividade pesqueira no Brasil (sub-item 2.1), constata-se que a preocupação com a sustentabilidade dos recursos naturais somente surge no último período analisado (1986-94), em decorrência do esgotamento dos estoques naturais de pescado. Cabe salientar que, desde então, a aqüicultura passou a ser alvo da política pesqueira nacional, desenvolvendo-se em várias regiões brasileiras, especialmente nos estados do Paraná, Santa Catarina, São Paulo e Minas Gerais, como uma alternativa de produção de proteína animal e, sobretudo, de geração de renda no meio rural.

De acordo com os dados da Tabela 2, observa-se que a maior parte da produção nacional de pescado ainda é proveniente da pesca extrativa, sendo pequena a contribuição da aqüicultura. Isto é uma decorrência da prática aqüícola extensiva predominante no país. No entanto, embora a participação da aqüicultura na produção brasileira de pescado ainda seja muito inferior à da pesca extrativa, é conveniente destacar que a produção de pescado cultivado, no período de 1984-98, apresentou uma tendência contínua de crescimento, com exceção do ano de 1994. A participação da 
aqüicultura (piscicultura mais maricultura) na produção nacional de pescado passou de 4,22\% no ano de 1984 para 31,41\% em 1998.

Segundo Castagnolli (1995), o recente crescimento da aqüicultura no Brasil se deve à diversidade ambiental e ao desenvolvimento tecnológico nas diferentes regiões geográficas do país. Desta forma, procurar-se-á descrever algumas características da produção aquiícola em cada uma das regiões brasileiras.

O perfil geográfico da região Sul que apresenta grandes áreas planas, onduladas e outras fracamente montanhosas lhe confere diversos microclimas que vão do tropical ao temperado. Essas características permitem o desenvolvimento de aqüicultura diversificada, com o cultivo de espécies de águas frias como trutas e ostras do Pacífico e, de águas mornas como tilápias, pacus, entre outros, o que lhes tem permitido responder pela maior produção de pescado cultivado no país. Segundo Workshop para subsidiar a capacitação de recursos humanos e a geração de tecnologia em aqüicultura sustentável apud Abdallah (1998), em 1995, foram produzidos mais de 19.000 toneladas de peixes, crustáceos e moluscos cultivados, por mais de 29.000 aqüicultores, em sua maioria pequenos proprietários. De acordo com Poli et al (2000), em 1998, a produção total da Região Sul foi de, aproximadamente, 56.635 toneladas de organismos aquáticos, tendo a participação de cerca de 69.672 aqüicultores, conforme Tabela 3.

Tabela 3. Estimativas do número de aqüicultores e produção da aqüicultura para consumo por região em 1995 e 1998

\begin{tabular}{lcccc}
\hline \multirow{2}{*}{ Região } & \multicolumn{2}{c}{$1995^{1}$} & \multicolumn{2}{c}{$1998^{2}$} \\
\cline { 2 - 5 } & $\begin{array}{c}\text { Número de } \\
\text { Aqüicultores }\end{array}$ & $\begin{array}{c}\text { Produção } \\
\text { (Ton/ano) }\end{array}$ & $\begin{array}{c}\text { Número de } \\
\text { Aqüicultores }\end{array}$ & $\begin{array}{c}\text { Produção } \\
\text { (Ton/ano) }\end{array}$ \\
\hline Sul & $>29.000$ & $>19.000$ & 69.672 & 56.635 \\
Sudeste & 2.443 & $10.897,9$ & 17.804 & 21.800 \\
Nordeste & 1.132 & $3.982,2$ & 2.440 & 26.418 \\
Norte & 3.582 & $2.079,5$ & 4.319 & 4.752 \\
Centro Oeste & 726 & 6.056 & 1.858 & 5.790 \\
\hline
\end{tabular}

Fonte: 1. Abdallah (1998, p.73); 2. Poli et al (2000); Pezzato \& Scorvo Filho (2000); Pereira et al (2000); Val et al (2000); Benites (2000); 
Segundo Workshop para subsidiar a capacitação de recursos humanos e a geração de tecnologia em aqüicultura sustentável apud Abdallah (1998), os estados do Paraná e Santa Catarina foram maiores produtores de pescado cultivado na região Sul no ano de 1995, respondendo por, aproximadamente, 90\% da produção regional. Em 1998, de acordo com Poli et al (2.000), o estado de Santa Catarina destacou-se como o maior produtor da região produzindo, aproximadamente, 22.650 toneladas de peixes, mexilhões, ostras e camarões, enquanto, os estados do Rio Grande do Sul e Paraná produziram, respectivamente, 17.448 e 16.537 toneladas de organismos aquáticos, no mesmo ano, destacando-se pela prática da piscicultura semi-intensiva no cultivo de várias espécies como carpas chinesas, bagres americano e africano, pacu e, principalmente, tilápias. Ainda de acordo com os mesmos autores, apesar do Paraná ter a menor área alagada por produtor (em média, 0,367 ha) obtém a maior produtividade da região, em torno de $2,026 \mathrm{~kg} / \mathrm{ha} / \mathrm{ano}$, enquanto nos estados de Santa Catarina e Rio Grande do Sul a produtividade média chega a $1.338 \mathrm{~kg} / \mathrm{ha} / \mathrm{ano}$ e $630 \mathrm{~kg} / \mathrm{ha} / \mathrm{ano}$, respectivamente.

Ainda com relação a disponibilidade de insumos, observa-se que a Região Sul dispõe de infra-estrutura para produção e distribuição dos insumos necessários ao desenvolvimento da aqüicultura, destacando-se o Paraná como o maior produtor regional de alevinos. Na safra 98/99 foram produzidos no Estado, aproximadamente, 200 milhões de alevinos que se destinaram não apenas a suprir a demanda estadual como também a de estados vizinhos.

O processo de comercialização e beneficiamento do pescado cultivado foi apontado como um dos pontos críticos da atividade na Região Sul devido ao baixo consumo per capita de pescado cultivado, ao seu baixo valor comercial e pela inexistência do beneficiamento dos produtos da piscicultura. No entanto, este quadro foi alterando-se gradativamente a partir da segunda metade dos anos 90, graças ao crescimento da indústria da pesca desportiva com o surgimento e propagação dos pesque-pagues e com a instalação de unidades de beneficiamento. Com relação ao número de unidades de beneficiamento em 1998, o Estado do Paraná contava com 16 unidades de beneficiamento de peixe, principalmente de tilápias, e duas unidades de 
beneficiamento de moluscos. Segundo Poli et al (2.000), o Estado de Santa Catarina, em 1998, contava com quatro unidades de beneficiamento de peixe e seis unidades especializadas em moluscos. Já no Estado do Rio Grande do Sul, de acordo com o mesmo autor, em 1998, duas empresas operavam no beneficiamento de peixe cultivado e outras duas atuavam no abate e processamento de rãs.

Ainda de acordo com o Workshop para subsidiar a capacitação de recursos humanos e a geração de tecnologia em aqüicultura sustentável apud Abdallah (1998), a região conta uma razoável infra-estrutura de ensino e pesquisa podendo-se o Laboratório de Maricultura e Aqüicultura Interior (FURG - RS), o Laboratório de Águas Interiores (UFSM - RS), o Laboratório para Pesquisa com Espécies de Água Doce (UFRGS - RS), a Estação de Aqüicultura de Itacorobi, a Estação de Maricultura da Barra da Lagoa e a Estação Experimental de Camboriú (UFSC - SC). Podem ainda ser nominados, a Estação de Pesquisas em Aqüicultura da Usina de Itaipu, o Centro de Pesquisas e Estudos em Piscicultura do Instituto Ambiental do Paraná (IAP) e a EMATER-Paraná que atua nas áreas de treinamento de produtores e extensão rural. Além das instituições acima mencionadas, também podem ser destacadas as Associações de Piscicultores no Estado do Paraná e as Cooperativas no Estado do Rio Grande do Sul, pelo importante papel desempenhado junto ao setor produtivo.

A região Sudeste, em 1995, produziu 10.987 ton/ano de organismos aquáticos cultivados (moluscos, crustáceos peixes e rãs) por cerca de 2.443 aqüicultores. Três anos depois, a atividade contava com 17.804 produtores cultivando aproximadamente 21.800 toneladas de organismos aquáticos, sendo o Estado de São Paulo o maior produtor da região, conforme Tabela 3.

De acordo com o Workshop para subsidiar a capacitação de recursos humanos e a geração de tecnologia em aqüicultura sustentável apud Abdallah (1998), a região Sudeste apresenta vários fatores favoráveis que a caracterizam como potencial para o desenvolvimento da aquiicultura. Entre eles podem ser citados: o alto nível de capacitação tecnológica; boa infra-estrutura para realizar pesquisas e treinamentos; um grande número de instituições que atuam em ensino, pesquisa, extensão e fomento à 
aquiicultura em todos os estados, grande potencial de produção e grande densidade populacional.

Segundo Castagnolli (1995), os piscicultores da região Sudeste cultivam uma grande variedade de espécies de peixe em diversos sistemas de produção, indo da suínopiscicultura, bastante praticada em Minas Gerais, até a criação intensiva de trutas arcoíris e de salmão na fronteira dos Estados de Minas Gerais e São Paulo. Neste último, também são cultivadas espécies nativas como pacu, tambaqui e curimbatá.

No que diz respeito ao beneficiamento da produção aquiúcola da região Sudeste observa-se uma grande concentração de plantas processadoras, em sua maioria, especializadas em pescado oriundo da pesca extrativa. No Estado de Minas Gerais, na Zona da Mata, encontravam-se em fase de implantação três unidades de processamento de pescado cultivado com capacidade para 15 ton/dia. No Estado de São Paulo, existem três unidades de beneficiamento de pescado cultivado sendo que uma única possui autorização do Serviço de Inspeção Sanitária e está temporiamente desativada e as outras duas processam de forma artesanal tilápias produzidas na região. Ainda, com relação aos moluscos cultivados, uma depuradora de ostras iniciou suas atividades em 1999 (Pezzato \& Scorvo, 2000).

Ainda de acordo com os mesmos autores, a produção de mexilhões, ostras e camarões cultivados na Região Sudeste ainda é, geralmente, comercializada nos mercados locais, em bares, restaurantes e diretamente ao consumidor final, principalmente, devido à baixa escala de produção que tem inviabilizado a comercialização junto às grandes redes de supermercados das capitais. Já os peixes cultivados são, predominantemente, comercializados juntos aos pesqueiros que demandam, aproximadamente, $90 \%$ da produção regional.

A região Nordeste também apresenta condições ambientais que a caracterizam como uma região potencial para o cultivo de organismos aquáticos. Além dos abundantes recursos hídricos e das condições climáticas excelentes com temperaturas elevadas e uniformes ao longo do ano que permitem cultivar várias espécies tropicais, com altos níveis de produtividade, o Nordeste, segundo Workshop para subsidiar a capacitação de recursos humanos e a geração de tecnologia em aqüicultura sustentável 
citado por Abdallah (1998), também caracteriza-se como a região do país que apresenta o segundo maior nível de qualificação do pessoal ocupado na aqüicultura. Esse quadro favorável explica o desempenho positivo do setor que, em 1995, contava com um número pequeno de aqüicultores, aproximadamente 1.132 produtores, e com uma produção cultivada próxima de 4.000 toneladas e que, em 1998, já possuía 2.440 produtores aqüícolas atingindo uma produção de 26.418 toneladas (ver Tabela 3).

Nessa região a aquiicultura se destaca principalmente na piscicultura e na carcinicultura ${ }^{3}$. A piscicultura nordestina produz espécies de pescado de água doce como tilápias, pescada, tucunaré e tambaqui. $O$ cultivo de camarão em água salgada teve início na década de 70, enquanto a carcinicultura de água doce é ainda recente (Abdallah, 1998).

No que diz respeito à disponibilidade de insumos, observa-se que sua oferta concentrada, principalmente, nos grandes centros, tem prejudicado o desenvolvimento da atividade aqüícola. $O$ principal problema enfrentado neste segmento da cadeia produtiva tem sido com a ração para peixe que apesar das evidentes melhorias na sua qualidade ainda requer investimentos para a produção de alimentos que atendam as necessidades particulares de cada espécie nas diferentes fases de crescimento, além dos elevados preços de venda, praticados pelas indústrias e distribuidoras do produto, que variam entre $R \$ 0,40$ e $R \$ 0,80 / \mathrm{kg}$ e que, em alguns casos, chegam a inviabilizar os projetos de cultivo (Perreira et al, 2000).

Ainda cabe destacar que a produção de sementes para a aqüicultura é realizada por trinta e nove estações de piscicultura que produzem, principalmente, alevinos de tilápia nilótica, tilápia vermelha e tambaqui e quatorze laboratórios de larvicultura de camarões, sendo onze especializados em produção de larvas de camarão marinho e três especializados em produção de larvas de camarões de água doce. Estima-se que, em 1998, a capacidade regional de produção de alevinos era de 233 milhões/ano, 5,5 bilhões de pós-larvas de camarão marinho e 14 milhões de pós-larvas de camarão de água doce (Perreira et al, 2000).

\footnotetext{
${ }^{3}$ Carcinicultura compreende a arte de cultivar crustáceos em cativeiro.
} 
Segundo os mesmos autores, apesar de contar com treze unidades de processamento de pescado e crustáceos, a região Nordeste precisa ampliar sua infraestrutura de beneficiamento do pescado, uma vez que, principalmente, os pequenos produtores, ainda não têm acesso à tecnologia de transformação. Isso explica porque a maior parte da produção de peixe cultivado é comercializada, no mercado local, salgado ou in natura (inteiro, eviscerado e fresco) e muito pouco, na forma de filé. Quanto à carcinicultura, de maneira geral, os grandes projetos possuem uma infra-estrutura própria de processamento e comercialização. No caso específico de camarões marinhos, cerca de $70 \%$ da produção cultivada destina-se ao mercado doméstico e o restante é exportado para a França, Espanha, Estados Unidos e Japão.

A região Centro-oeste, de acordo com a Tabela 3, é a região que possui o menor número de aqüicultores, embora não seja a menor produtora de pescado cultivado. Isso se deve à excelente qualidade da água, ao clima favorável à pratica da piscicultura e à característica fundiária da região, onde predominam grandes propriedades.

Segundo Castagnolli (1995), nessa região são cultivados, predominantemente, peixes nativos como pacu, tambaqui, pintado e dourado. Segundo Benites (2000), isso se explica, em parte, pela existência do Decreto Estadual No 1826 de 12/01/98 que proíbe a criação de espécies exóticas na região da Bacia do Alto Paraguai.

Ainda segundo o mesmo autor, existem vinte e seis entidades públicas e privadas envolvidas com atividades de regulamentação, organização, fiscalização, ensino, pesquisa, extensão, fomento e crédito para a aqüicultura regional. No entanto, de acordo com o Workshop para subsidiar a capacitação de recursos humanos e a geração de tecnologia em aqüicultura sustentável citado por Abdallah (1998), o grande entrave ao maior desenvolvimento da atividade aqüícola na região Centro-oeste do Brasil é a insuficiência de serviços de extensão que proporcionem transferência de tecnologia aos produtores.

De acordo com Benites (2000), não há carência de insumos básicos para aqüicultura no mercado regional. A única questão que merece destaque é o elevado preço da ração para peixe que ainda onera muito os custos de produção, mesmo sendo a região Centro-oeste uma grande produtora e exportadora de soja e milho que são 
componentes básicos na formulação de rações animais.

Com relação ao processamento, a região conta apenas com duas unidades de beneficiamento de rãs, uma no Distrito Federal e outra em Goiás. $O$ peixe produzido ainda é, predominantemente, comercializado vivo para pesque-pagues, pesca desportiva e consumo durante a Semana Santa. Quanto ao filé, a preferência é para a tilápia, já produzida em algumas microrregiões (Benites, 2000).

A Região Norte é quase totalmente coberta por florestas tropicais, drenadas para o Oceano Atlântico através do Rio Amazonas, e apresenta um grande potencial para aqüicultura. A sobrepesca comercial e artesanal vem causando uma redução nos estoques de pescado nas água interiores. Segundo Castagnolli (1995), estes fatos, aliados aos riscos de contaminação pelo mercúrio das minerações de ouro, têm estimulado o desenvolvimento da piscicultura na região, principalmente com a criação de tambaqui, curimatã e pirarucu. Além dessas espécies nativas, também são cultivadas algumas espécies exóticas destacando-se entre elas, as carpas e as tilápias.

Já na planície Amazônica, apesar das favoráveis condições climáticas e das águas de excelente qualidade para aqüicultura, a população diminuta, a necessidade de elevados investimentos em infra-estrutura de produção, processamento e distribuição e a dificuldade de acesso aos grandes centros consumidores se constituem em sérias limitações para o desenvolvimento dessa atividade.

Com relação ao número de aqüicultores, em 1995, a região Norte ocupava o segundo lugar, com 3.582 piscicultores, embora apresentasse a mais baixa produção de pescado proveniente da aqüicultura, estimada em 2.080 t/ano. Em 1998, a região passou a contar com 4.319 produtores e com uma produção estimada em 4.752 toneladas (Tabela 3).

De acordo com Val et al (2000), os cultivos extensivos são praticados por $59,8 \%$ dos aqüicultores da região, enquanto $38,4 \%$ destes praticam a aqüicultura semiintensiva e apenas $1,8 \%$ destes realizam cultivos intensivos.

Com relação à larvicultura, existem na região dezenove estações de produção com capacidade instalada para produzir 35,3 milhões de alevinos/ano, embora a produção efetiva não ultrapasse os 13 milhões de alevinos por ano. No entanto, 
considerando a taxa de estocagem média da região, constata-se que a produção real é suficiente para povoar a área total de cultivo existente. Segundo Rolim (1995), a concentração da produção de alevinos, em torno dos grandes centros urbanos, tem dificultado a distribuição para as regiões do interior.

A Região Norte conta com empresas especializadas no beneficiamento, resfriamento e estocagem de pescado, embora nem sempre tenham sido planejadas para dar apoio à aquiicultura. Existe uma empresa no Estado do Amapá e uma no Estado de Rondônia, ambas com inspeção sanitária e com capacidade potencial para 10 toneladas/dia que foram planejadas para atender especificamente a atividade aquiícola.

Com exceção dos Estados do Acre e do Pará, todo o pescado oriundo da produção cultivada na Região Norte é consumido no mercado local e comercializado inteiro, fresco ou resfriado. Essas formas de comercialização decorrem das características culturais e sociais da população regional e também da incipiente estrutura de beneficiamento, distribuição e comercialização da Região. No entanto, não se pode descartar as reais potencialidades de mercado para produtos industrializados tais como, hamburguers, embutidos, defumados e enlatados. A possibilidade de se investir na industrialização e comercialização do pescado, além favorecer a elevação da renda local, também permitiria reduzir as elevadas taxas de desperdício verificadas. Estima-se que, aproximadamente, $13,6 \%$ das 150 toneladas de pescado, diariamente, capturadas e desembarcadas em Manaus é desperdiçado por falta de infra-estrutura de transporte e beneficiamento (Val et al, 2000).

Outro ponto crítico para a aqüicultura na região Norte é a indisponibilidade de insumos, tais como adubo químico, alevinos, produtos químicos, equipamentos e especialmente ração para peixe.

A região Norte conta em todos os seus estados com instituições de fomento à aqüicultura. Já os centros de formação profissional e pesquisa se concentram na Amazônia e no Pará, com destaque principalmente para a Universidade Federal do Amazonas e o Instituto Nacional de Pesquisas da Amazônia (INPA), situados em Manaus-AM, e o Centro de Pesquisas Agropecuárias do Trópico Úmido (CPATU) localizado em Belém-PA. 
O atual quadro da produção aquíícola regional pode ser explicado pela distribuição dos incentivos fiscais destinados ao fomento da pesca no país. De acordo com Abdallah (1998), as regiões brasileiras que mais produzem pescado são também as que mais receberam incentivos fiscais para desenvolver esse setor (Sudeste, 53\%; Sul, 24,51\%; Nordeste, 15,27\%; Norte, 5,71\% e Centro Oeste, 1,5\%).

Ao final dessa suscinta revisão da produção aquíícola nas grandes regiões do Brasil, constata-se a existência de um grande potencial para o desenvolvimento de uma aqüicultura intensiva e diversificada dada a grande quantidade e qualidade dos recursos hídricos disponíveis, às condições climáticas favoráveis e, sobretudo, ao mercado consumidor potencial a ser atendido.

Considerando que o objeto de estudo deste trabalho é a indústria paranaense de beneficiamento de tilápias cultivadas, no próximo item far-se-á uma análise de como evoluiu a aquiicultura paranaense.

\subsection{A aquiicultura no Estado do Paraná}

No estado do Paraná, o programa de manejo e conservação de solos, desenvolvido pela Secretaria de Estado da Agricultura em convênio com a EMATERParaná e a CODAPAR, foi um importante fator para o desenvolvimento da piscicultura, pois permitiu conter a degradação do solo e melhorar a qualidade das águas existentes, dando início ao replanejamento das propriedades envolvidas através do melhor aproveitamento dos solos agricultáveis e dos mananciais de água (Rissato, 1995).

A piscicultura no Paraná também foi estimulada pela grande necessidade de diversificar as atividades como forma de complementar a renda do pequeno produtor ameaçada por fatores como o desgaste gradativo dos solos agricultáveis (devido à intensa exploração da agricultura em sistema de monocultura mecanizada), a sazonalidade dos preços dos produtos agrícolas e a falta de crédito rural (Rissato, 1995).

Considera-se que a criação do Centro de Pesquisa em Aquicultura Ambiental (CPAA) em Toledo-PR (1981), das Estações de Alevinagem de Jaguariaíva, pela atual 
CODAPAR, e das Estações de Alevinagem de Francisco Beltrão, Paranavaí e Loanda sob supervisão da Superintendência de Recursos Hídricos e Meio Ambiente (SUREHMA), atualmente Instituto Ambiental do Paraná (IAP), na década de 80, foi o marco inicial da piscicultura comercial no Estado do Paraná. Em 1982, foi implantado o Programa Regional de Piscicultura da EMATER-Paraná, que tinha como objetivo a produção de alevinos de espécies exóticas como carpas e tilápias .

No entanto, somente a partir da segunda metade da década de 80 , verificou-se uma significativa expansão da piscicultura, especialmente na região Oeste do Estado, estimulada pelo Programa de Pesca e Aquicultura, criado em 1987, pela Secretaria de Estado da Agricultura e do Abastecimento, que concedia subsídios em horas/máquina para a construção de viveiros para piscicultura. Esse programa tinha como objetivos aumentar a produção de pescado cultivado, organizar os produtores e a produção, bem como promover o melhoramento genético das espécies cultivadas.

Um dos grandes problemas enfrentados pela atividade foi a escassez de alevinos, já que a região dependia exclusivamente da produção do CPAA, quantidade esta insuficiente para atender a demanda regional. A partir de 1989, o CPAA passou a dedicar-se somente à pesquisa e à produção de espécies nativas da bacia do rio Paraná para povoar as represas, construídas com a finalidade de gerar energia elétrica no Estado, cabendo, a partir de então, à iniciativa privada a produção comercial de alevinos.

Desde o início dos anos 90, a piscicultura vem se destacando como uma atividade econômica nas propriedades rurais do Estado, com o desenvolvimento de um complexo piscícola a partir do surgimento de uma série de atividades que direta e indiretamente estão relacionadas a ela, tais como as indústrias de ração, a produção de alevinos em maiores escalas, a indústria de beneficiamento, os pesque-pagues, etc.

Em 1992, uma nova tecnologia veio viabilizar a criação de tilápias em escala comercial, inclusive em períodos de entressafra, justamente por permitir altas produtividades na produção de alevinos dessa espécie, elevando significativamente as quantidades ofertadas, bem como a qualidade deste insumo. Tratava-se da reversão sexual de tilápias, uma técnica amplamente difundida e praticada em países onde a piscicultura é mais desenvolvida. 
Essa técnica ${ }^{4}$ consiste em definir o sexo dos peixes no período larval, já que a espécie não tem sexo definido até os primeiros 30 dias de vida, e que o macho cresce de 2 a 5 vezes mais rápido do que a fêmea.

Ainda, em 1992, a Cooperativa Agrícola Mista Rondon Ltda - COOPAGRIL de Marechal Cândido Rondon com assessoria de profissionais da Universidade Federal do Paraná e o apoio da EMATER-Paraná, desenvolveu uma ração para peixe que foi lançada comercialmente, em fevereiro de 1993, em um Dia de Campo. Nesta mesma ocasião foram apresentados os resultados de um experimento de criação intensiva de tilápias utilizando alevinos sexualmente revertidos, ração balanceada para peixe e aeradores automáticos.

Esse Dia de Campo pode ser considerado um marco no processo de tecnificação da atividade, pois nessa data foi lançada aos piscicultores paranaenses a proposta de implementação de três novas tecnologias, que hoje já são adotadas por cerca de $90 \%$ dos piscicultores do Estado e que foram essenciais no processo de profissionalização da atividade.

Em setembro de 1993, surge o primeiro frigorífico de filetagem de peixes cultivado do Brasil, no município de Assis Chateaubriand. Esse é outro fator muito importante para explicar o desenvolvimento da atividade, pois a comercialização do pescado pelo produtor, desde a década de 80, era apontada como um dos principais pontos de estrangulamento da piscicultura. Ainda, de acordo com pesquisa realizada em 1992, as unidades de beneficiamento do peixe cultivado vieram atender a grande expectativa dos produtores do Estado que sofriam com o funcionamento sazonal do mercado de pescado (Rissato, 1995).

Por outro lado, se o setor de beneficiamento deu maiores expectativas de mercado aos produtores, ele também foi o principal responsável pela profissionalização

\footnotetext{
${ }^{4}$ Devido a sua alta fecundidade e precocidade reprodutiva, as tilápias apresentam tendência de atrofiamento dos indíviduos e superpovoamento dos viveiros, o que impede que atinjam tamanho comercial satisfatório. A prática mais usual é impedir a reprodução com a criação de apenas peixes machos. Para isso, as larvas de tilápias são coletadas antes mesmo que tenham seu sexo definido, acondicionadas em tanques especiais e alimentadas com ração preparada com hormônio masculino durante, aproximadamente, 30 dias, tempo suficiente para ocorrer a masculinização de pelo menos $95 \%$ das larvas.
} 
do setor produtivo que precisou incorporar a tecnologia disponível e melhorar seu desempenho técnico já que a indústria, normalmente, remunera o produtor de acordo com a taxa percentual de rendimento de filé. Exemplo disso é a diferença da qualidade do pescado entregue às unidades de beneficiamento no início da década de 90 , que apresentava produção pequena, peixes de peso e tamanhos heterogêneos e com baixas porcentagens de rendimento de filé, em torno de $30 \%$. Hoje, as unidades de beneficiamento funcionam durante o ano todo, exigindo peso médio padrão de $350 \mathrm{~g}$, descartando toda a produção com peso inferior. A resposta por parte do setor produtivo foi rápida, já que, quando o setor de beneficiamento de pescado começou a operar no mercado, um pacote tecnológico mínimo já era conhecido pelo pessoal técnico e disponibilizado aos produtores interessados.

Desde então, a piscicultura paranaense tem crescido significativamente com surgimento de novas empresas nos diversos segmentos da cadeia produtiva

De acordo com Sugai et al (1998), o faturamento bruto total da cadeia produtiva da piscicultura estadual, no ano de 1997, foi de $\mathbf{R} \$ 66.833 .220,00$ (Tabela 4).

Tabela 4. Faturamento bruto dos diversos setores da cadeia produtiva da piscicultura paranaense em 1997.

\begin{tabular}{lcc}
\hline Valor bruto da produção primária & $\mathrm{R} \$ 24.589 .800,00$ & 36,79 \\
Valor bruto da produção industrial & $\mathrm{R} \$ 1.673 .000,00$ & 2,50 \\
Valor bruto dos pesque-pagues & $\mathrm{R} \$ 37.565 .000,00$ & 56,21 \\
Valor bruto das feiras & $\mathrm{R} \$ 3.005 .420,00$ & 4,50 \\
TOTAL & $\mathrm{R} \$ 66.833 .220,00$ & $100 \%$ \\
\hline
\end{tabular}

Fonte: Sugai et al (1998)

De acordo com os mesmos autores, os pesque-pagues faturaram $56,21 \%$ deste valor, seguidos dos produtores rurais que ficaram com $36,79 \%$ do valor gerado. Com relação à indústria, cabe destacar, que a sua pequena participação na receita bruta gerada 
pelo setor se deve, principalmente, à baixa escala de produção e ao fato do produto ser pouco processado (Tabela 4).

Ainda, segundo Sugai et al (1998), estima-se que a piscicultura gerou cerca de 108.032 empregos diretos e indiretos em todo o Estado durante o ano de 1997, sendo que $96,35 \%$ dessa mão-de-obra está empregada nas propriedades rurais e que os pesquepagues, as feiras livres e a indústria são responsáveis por $1,99 \%, 1,48 \%$ e $0,18 \%$ desses empregos, respectivamente.(Tabela 5).

Tabela 5. Estimativa da mão-de-obra ocupada pela piscicultura paranaense em diversos setores em 1997

\begin{tabular}{lcc}
\hline Setor & Números de Pessoas & $\%$ \\
\hline Propriedades rurais & 104.085 & 96,35 \\
Pesque-pagues & 2.147 & 1,99 \\
Indústrias & 200 & 0,18 \\
Feiras & 1.600 & 1,48 \\
TOTAL & 108.032 & $100 \%$ \\
\hline
\end{tabular}

Fonte: Sugai et al (1998)

A seguir apresenta-se uma suscinta caracterização de cada segmento do complexo piscícola no Estado do Paraná. O sistema agroindustrial do pescado cultivado em água doce se constitui do setor de fatores e insumos, setor produtivo, de transformação, de distribuição e consumo.

\subsubsection{Setor de insumos}

$\mathrm{O}$ primeiro segmento de qualquer complexo produtivo agroindustrial compreende justamente os setores responsáveis pelo suprimento de material biológico, material produtivo e equipamentos. No caso específico da piscicultura paranaense, este segmento da cadeia produtiva compõe-se de produtores de alevinos, indústrias de ração, 
indústrias e distribuidores de máquinas, motores e equipamentos para aqüicultura, fábricas e distribuidores de materiais, apetrechos e utensílios de manejo e despesca e assistência técnica especializada. Estes são, sem dúvidas, setores especializados que surgiram e se estruturaram no mercado para atender e dar suporte à atividade produtiva propriamente dita.

No Estado do Paraná, na safra 96/97, foram produzidos cerca de 218,4 milhões de alevinos com a participação de 96 produtores, sendo que 50\% destes estavam instalados na região Oeste Paranaense respondendo por 64,5\% da produção estadual de alevinos. Observa-se uma redução de, aproximadamente, $22,64 \%$ na produção de alevinos na Safra 97/98, quando foram produzidos 168,9 milhões de alevinos por 97 produtores instalados em diversas regiões do Estado, conforme Tabela 6.

De acordo com Parizoto (1999), na região Oeste do Paraná formada pelas macrorregiões de Toledo e Cascavel, a produção de alevinos em unidades, no mesmo período, foi de 77,8 milhões de unidades, gerando uma renda de aproximadamente, $\mathrm{R} \$ 2,3$ milhões de reais. Deste total produzido, 63,49 milhões foram alevinos de tilápias ( $81,58 \%$ do total produzido) e 14,32 milhões foram alevinos das outras espécies.

No ano 2000, segundo Darife $(2001)^{5}$, foram comercializados aproximadamente 51,3 milhões no Estado do Paraná. Ainda, segundo Martins et al (2000), 96\% dos piscicultores da região oeste do estado cultivam tilápias, sendo que $39 \%$ destes cultivam, exclusivamente, tilápias-do-nilo. Isto demonstra que realmente a atividade piscícola na região Oeste do Paraná tem na tilapicultura a sua maior representatividade.

${ }^{5}$ Darife, Alsir Luiz. Associação Toledana de Aquicultores. Toledo-PR. Comunicação pessoal, em $22 / 08 / 2001$. 
Tabela 6. Número de produtores de alevinos e quantidade comercializada nas safras 96/97 e 97/98 no Estado do Paraná.

\begin{tabular}{lcccc}
\hline Macrorregiões & \multicolumn{2}{c}{ Safra $96 / 97^{1}$} & \multicolumn{2}{c}{ Safra $97 / 98^{2}$} \\
\cline { 2 - 5 } & $\begin{array}{c}\mathrm{N}^{\mathrm{o}} \text { de } \\
\text { Produtores }\end{array}$ & $\begin{array}{c}\text { Quantidade } \\
\text { de Alevinos }\end{array}$ & $\begin{array}{c}\mathrm{N}^{\circ} \text { de } \\
\text { Produtores }\end{array}$ & $\begin{array}{c}\text { Quantidade } \\
\text { de Alevinos }\end{array}$ \\
\hline Paranaguá & 02 & 5.030 & 03 & 7.300 \\
Curitiba & 04 & 600 & 06 & 345 \\
União da Vitória & 03 & 200 & 02 & 250 \\
Ponta Grossa & - & - & 01 & - \\
Guarapuava & 03 & 230 & 02 & 70 \\
Irati & 03 & 500 & 04 & 350 \\
Lapa & 02 & 520 & 02 & 590 \\
Umuarama & 01 & - & 01 & 1.000 \\
Campo Mourão & 02 & 1.530 & 04 & 925 \\
Apucarana & 01 & 20 & 02 & 270 \\
Paranavaí & 02 & 370 & 03 & 370 \\
Maringá & 02 & 1.800 & 05 & 2.800 \\
Ivaiporã & 01 & - & - & - \\
Londrina & 06 & 51.500 & 06 & 18.650 \\
Cornélio Procópio & 03 & 7.090 & 04 & 6.800 \\
Sto Antônio da Platina & 04 & 5.175 & 04 & 110 \\
Pato Branco & 04 & 2.287 & 04 & 2.880 \\
Francisco Beltrão & 05 & 600 & 03 & 600 \\
Cascavel & 10 & 47.382 & 07 & 5.745 \\
Toledo & 38 & 93.562 & 37 & 119.896 \\
TOTAL & 96 & 218.396 & 97 & 168.951 \\
\hline & 02 & 04 & & \\
\hline
\end{tabular}

Fonte: 1. EMATER-Paraná, 1997; 2. EMATER-Paraná, 1998. 
Já no caso das indústrias de ração para peixe, de acordo com Oshima ${ }^{6}$, estimase que em 1999, foram produzidas, em média, 18.000 ton de ração para peixe no Estado do Paraná, o que representou um faturamento de $\mathbf{R} \$ 7,2$ milhões para o setor. Ainda segundo Oshima, a produção paranaense corresponde, aproximadamente, a $20 \%$ da produção nacional de ração peixe. De acordo com Darife (2001), no ano 2000, foram comercializadas, aproximadamente, 20,8 mil toneladas de ração para peixe no Paraná, utilizadas para produzir cerca de 17 mil toneladas de pescado cultivado.

Com relação às empresas fabricantes, importadoras e distribuidoras de equipamentos, máquinas e motores e de apetrechos e materiais de manejo e despesca ainda não se tem estimativas.

No entanto, cabe lembrar que a piscicultura requer também bens e serviços de outras empresas que não se instalaram para atender especificamente ao setor piscícola e ou o setor pesqueiro em geral, como por exemplo, energia elétrica, mão-de-obra não qualificada, distribuidores de fertilizantes e calcário; fretes, entre outros.

De acordo com a Tabela 7, é possível identificar os principais componentes do segmento de fatores e insumos e sua respectiva participação percentual nos custos totais de produção de tilápias cultivada no Extremo Oeste Paranaense.

Tabela 7. Participação relativa das despesas com os principais insumos e fatores de produção nos custos totais de produção de tilápias no Estado do Paraná.

\begin{tabular}{lcc}
\hline Itens & \% dos Custos Totais $^{1}$ & \% dos Custos Totais $^{2}$ \\
\hline Alevinos & 3,12 & 4,71 \\
Ração & 27,22 & 24,54 \\
Mão-de-obra & 32,55 & 36,84 \\
Fertilizantes & 24,02 & 10,08 \\
Cal Virgem/Calcário & 0,29 & 0,40 \\
Energia Elétrica & - & 0,77 \\
Equipamentos/utensílios & 6,08 & 5,17 \\
Análise química & 0,18 & 1,64 \\
\hline
\end{tabular}

Fonte: 1. Rissato (1995); 2. GEPEC (mês 04/2001)

\footnotetext{
${ }^{6}$ Oshima, Hilton Hiroshi. Alisul Alimentos S/A. Maringá-PR. Comunicação pessoal, 27/12/1999.
} 
Observa-se que, em cultivos com densidade de estocagem equivalente a 3 peixes $/ \mathrm{m}^{2}$, a ração e a mão-de-obra são os insumos que têm a maior participação relativa nos custos totais de produção, em ambos os estudos. Apesar de se observar reduções na participação de alguns fatores nos custos totais de produção, como é o caso da ração e dos fertilizantes, que podem refletir uma maior eficiência no manejo dos cultivos, constata-se que a ração é o segundo fator que mais onera os custos de produção.

\subsubsection{Segmento produtivo}

O segundo elo da cadeia é o setor produtivo que, no caso da piscicultura, é representado pelos produtores de peixe cultivado. A piscicultura paranaense surge primeiro no oeste do estado, estendendo-se, posteriormente, às outras regiões. Atualmente, a piscicultura é praticada em todo o Paraná e, segundo Sugai et al (1998), a tecnologia de produção existente é de nível intermediário, com baixas densidades de estocagem e com emprego não intensivo de fatores.

De acordo com dados da Tabela 8 , constata-se a produção aqüícola estadual tem crescido no período de 1997 a 1999. Entre 1997 e 1998, verificou-se um crescimento médio, no Estado, da ordem de 20,17\%. Já a produção de 1999 cresceu, em média, 7\% em relação ao ano de 1998.

A região Norte é formada pelas microrregiões de Cornélio Procópio, Santo Antônio da Platina, Ivaiporã, Paranavaí, Maringá, Londrina e Apucarana e, em 1999, possuía o quarto maior número de piscicultores e a terceira maior área, no entanto, foi o segundo pólo que mais produziu, respondendo por $28,09 \%$ da produção total de peixe do Estado. Isto pode ser explicado pela produtividade média obtida em 1999, de $2.753 \mathrm{~kg}$ de peixe por hectare de viveiro, conforme Figura 1.

A região Oeste, constituída pelas microrregiões de Toledo e Cascavel, contava, em 1999, com a maior área em viveiros respondendo por $48 \%$ da produção piscícola do Estado, com uma produtividade estimada de $3.725 \mathrm{~kg}$ de peixe por hectare de viveiro (Figura 1). 
Tabela 8. Evolução da produção da piscicultura no Estado do Paraná no período de 1997

\begin{tabular}{lccc}
\multicolumn{1}{c}{ a 1999} & & & \\
\hline \multicolumn{1}{c}{ Núcleos regionais da } & 1997 & 1998 & 1999 \\
\hline EMATER-Paraná & & & 233 \\
Curapuava & 200 & 169 & 419 \\
Parianaga & 336 & 371 & 131 \\
U. Vitória & 100 & 227 & 145 \\
Ponta Grossa & 159 & 205 & 175 \\
Irati & 135 & 220 & 128 \\
Lapa & 100 & 116 & 108 \\
Ivaiporã & 120 & 166 & 302 \\
Umuarama & 500 & 330 & 713 \\
Paranavaí & 47 & 638 & 157 \\
Maringá & 47 & 152 & 561 \\
Londrina & 500 & 557 & 538 \\
C. Procópio & 200 & 437 & 2562 \\
S. A. Platina & 2000 & 2318 & 617 \\
C. Mourão & 548 & 889 & 809 \\
Apucarana & 110 & 582 & 199 \\
Toledo & 505 & 180 & 5952 \\
Cascavel & 5120 & 5826 & 2508 \\
Pato Branco & 2215 & 2052 & 559 \\
Francisco Beltrão & 416 & 573 & 763 \\
& 303 & 432 & 17.573 \\
\hline
\end{tabular}

Fonte: EMATER-Paraná (1999).

Composta pelas microrregiões de Francisco Beltrão e Pato Branco, a região Sudoeste contava, em 1999, com o segundo maior número de piscicultores e com a segunda maior área alagada destinada ao cultivo de pescado ocupando, no entanto, apenas o terceiro lugar enquanto região produtora, em decorrência da baixa produtividade obtida pelos produtores que foi, em média, de $865 \mathrm{~kg}$ de peixe por hectare de tanque (Figura 1).

A região Sul, representada pelas microrregiões de Paranaguá, Guarapuava, União da Vitória, Ponta Grossa, Irati, Lapa e Curitiba, possuía, em 1999, o terceiro maior número de piscicultores e a maior área destinada à piscicultura, produzindo um pequena quantidade de pescado, aproximadamente, $7,62 \%$ da produção estadual. Os produtores desta região também obtém uma baixa produtividade, cerca de $682 \mathrm{~kg}$ de peixe por hectare de lâmina d'água, conforme Figura 1. 


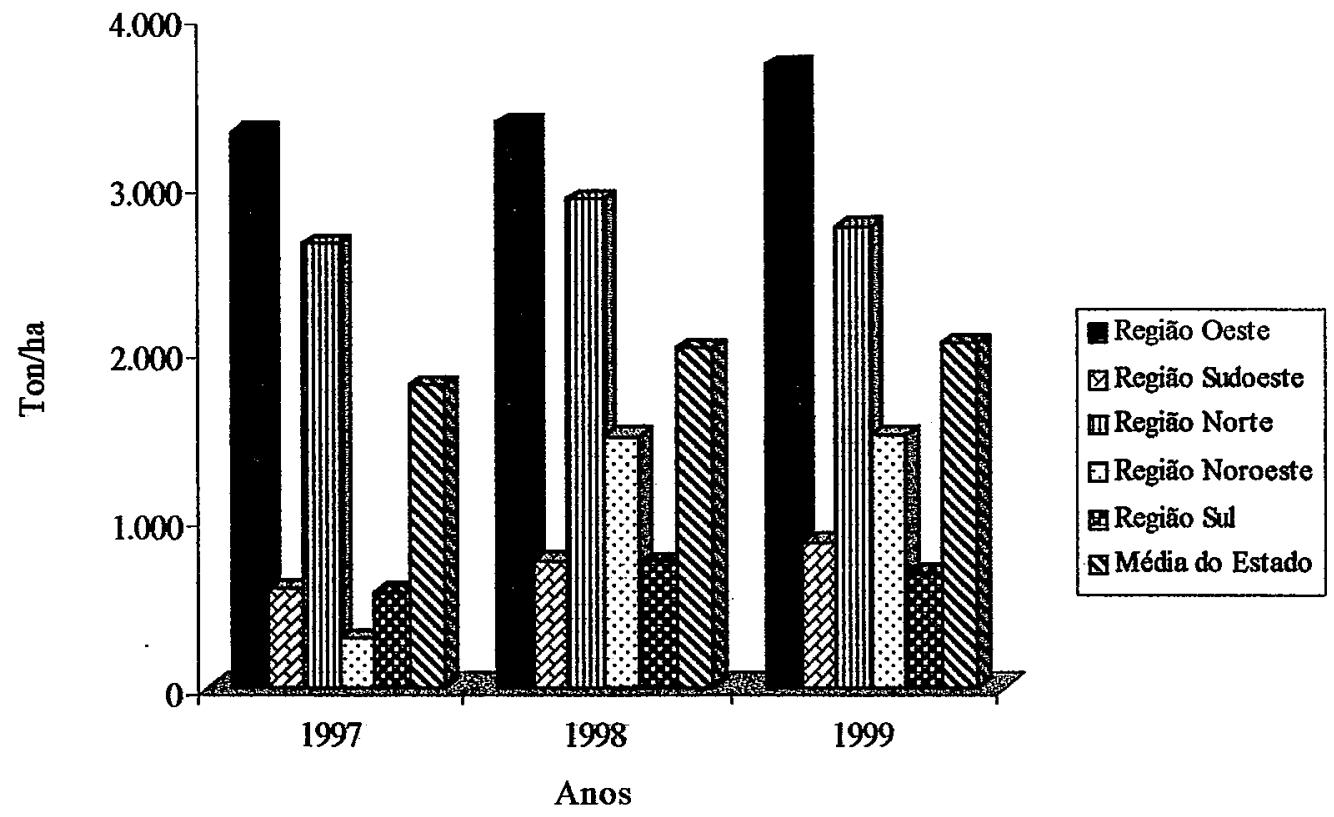

Figura 1 - Produtividade média estadual e regional no período de 1997 a 1999.

A região Noroeste formada pelas microrregiões de Campo Mourão e Umuarama foi a terceira região que mais produziu, apesar de possuir o menor número de piscicultores e também a menor área alagada do Estado obtendo, aproximadamente, $1508 \mathrm{~kg}$ de peixe por hectare de viveiro (Figura 1).

As diferentes produtividades obtidas nas cinco regiões do Estado do Paraná se devem às diferenças climáticas de cada região e aos diferentes níveis de intensificação do uso de fatores produtivos. Observa-se que nas regiões Sudeste e Sul onde se registram as temperaturas mais baixas do Estado foram obtidas as menores produtividades, enquanto as regiões Norte e Noroeste que apresentam as mais elevadas temperaturas do Estado e a região Oeste que foi pioneira na prática da piscicultura comercial obtiveram produtividade muito superior à média do Estado, no período de 1997/99, conforme (Figura 1).

De acordo com a Tabela 9, a área de lâmina d'água destinada ao cultivo de pescado no Estado do Paraná apresentou taxas de crescimento positivas no periodo de 
1995 a 1999. Esse crescimento da área alagada foi motivado, principalmente, pela crescente demanda de peixe vivo e os pelos elevados preços pagos pelos pesque-pagues do Estado do Paraná e de São Paulo.

Tabela 9. Evolução na área (ha) de lâmina d'água para piscicultura no Paraná no período de 1995 a 1999

\begin{tabular}{|c|c|c|c|c|c|c|c|c|c|c|}
\hline Região & 1995 & $\begin{array}{l}\text { Var } \\
(\%)\end{array}$ & 1996 & $\begin{array}{l}\text { Var } \\
(\%)\end{array}$ & 1997 & $\begin{array}{l}\text { Var } \\
(\%)\end{array}$ & 1998 & $\begin{array}{l}\text { Var } \\
(\%)\end{array}$ & 1999 & $\begin{array}{l}\text { Var } \\
(\%)\end{array}$ \\
\hline Paranaguá & 85 & - & 110 & 29,41 & 303 & 175,45 & 146 & $-51,82$ & 91 & $-37,67$ \\
\hline Curitiba & 256 & - & 625 & 144,14 & 500 & $-20,00$ & 568 & 13,60 & 659 & 16,02 \\
\hline União da Vitória & 115 & - & 430 & 273,91 & 479 & 11,40 & 431 & $-10,02$ & 452 & 4,87 \\
\hline Ponta Grossa & 174 & - & 289 & 66,09 & 327 & 13,15 & 338 & 3,36 & 237 & $-29,88$ \\
\hline Guarapuava & 185 & - & 333 & 80,00 & 99 & $-70,27$ & 186 & 87,88 & 197 & 5,91 \\
\hline Irati & 144 & - & 162 & 12,50 & 201 & 24,07 & 133 & $-33,83$ & 156 & 17,29 \\
\hline Lapa & 96 & - & 129 & 34,37 & 103 & $-20,15$ & 162 & 57,28 & 172 & 6,17 \\
\hline Umuarama & 62 & - & 170 & 174,20 & 124 & $-27,05$ & 201 & 62,10 & 216 & 7,46 \\
\hline Campo Mourão & 189 & - & 471 & 149,20 & 404 & $-14,22$ & 615 & 52,23 & 793 & 28,94 \\
\hline Apucarana & 150 & - & 82 & $-45,33$ & 76 & $-7,31$ & 59 & $-22,37$ & 73 & 23,73 \\
\hline Paranavaí & 54 & - & 40 & $-25,92$ & 90 & 125,00 & 79 & $-12,22$ & 90 & 13,92 \\
\hline Maringá & 84,9 & - & 130 & 53,12 & 151 & 116,15 & 220 & 45,70 & 231 & 5,00 \\
\hline Ivaiporã & 313 & - & 104 & $-66,77$ & 394 & 278,84 & 281 & $-28,68$ & 326 & 16,01 \\
\hline Londrina & 79,7 & - & 287 & 260,10 & 297 & 3,48 & 130 & $-56,23$ & 125 & $-3,85$ \\
\hline Cornélio Procópio & 216 & - & 275 & 27,31 & 444 & 61,45 & 549 & 23,65 & 447 & $-18,58$ \\
\hline Sto Ant.da Platina & 92 & - & 380 & 313,04 & 168 & $-55,79$ & 346 & 105,95 & 501 & 44,80 \\
\hline Pato Branco & 221 & - & 528 & 138,91 & 699 & 32,38 & 801 & 14,59 & 977 & 21,97 \\
\hline Francisco Beltrão & 117 & - & 316 & 170,08 & 509 & 61,07 & 527 & 3,54 & 552 & 4,74 \\
\hline Cascavel & 379 & - & 573 & 51,18 & 727 & 26,87 & 883 & 21,46 & 764 & $-13,48$ \\
\hline Toledo* & 1383 & - & 1198 & $-13,50$ & 1479 & 23,45 & 1449 & $-2,03$ & 1507 & 4,00 \\
\hline TOTAL & 4396 & - & 6632 & 50,86 & 7574 & 14,20 & 8.103 & 6,98 & 8566 & 5,71 \\
\hline
\end{tabular}

Fonte: EMATER-Paraná, (1999).

No entanto, a inadimplência dos pesque-pagues e dos intermediários que faziam o transporte de peixe vivo, durante a safra 97/98, acarretou grandes prejuízos aos piscicultores, refletindo-se na redução dos investimentos em construção de novas áreas e 
no abandono total ou parcial das áreas já construídas. Enquanto, em 1997, a área de lâmina d'água para piscicultura cresceu $14,20 \%$, no ano de 1999, este crescimento foi de apenas $5,71 \%$.

Observa-se também que, de acordo com a Tabela 9, as regiões Oeste e Sudoeste do Paraná possuem a maior área de lâmina d'água para piscicultura do Estado, a qual cresceu no período de 1995 a 1996, mantendo-se constante a partir de 1997 (Tabela 9 e Figura 2).

Isso se deve ao fato da região Oeste ter iniciado a prática da piscicultura, ainda na década de 80, tendo sido, portanto, a maior beneficiada pelos incentivos do Governo do Estado que, através da Secretaria da Agricultura e do Abastecimento - SEAB subsidiou em $50 \%$ o pequeno produtor e em $30 \%$ o médio produtor na construção de tanques para a piscicultura e que implementou o programa "Panela Cheia". Este programa financiou, através da equivalência por produto, a implantação de projetos de tanque-rede, de piscicultura em viveiros escavados e de unidades de beneficiamento, bem como a aquisição de ração e equipamentos, com possibilidade de financiamento no valor de até 1000 sacas de milho, por produtor, com prazo de pagamento de até três anos. 


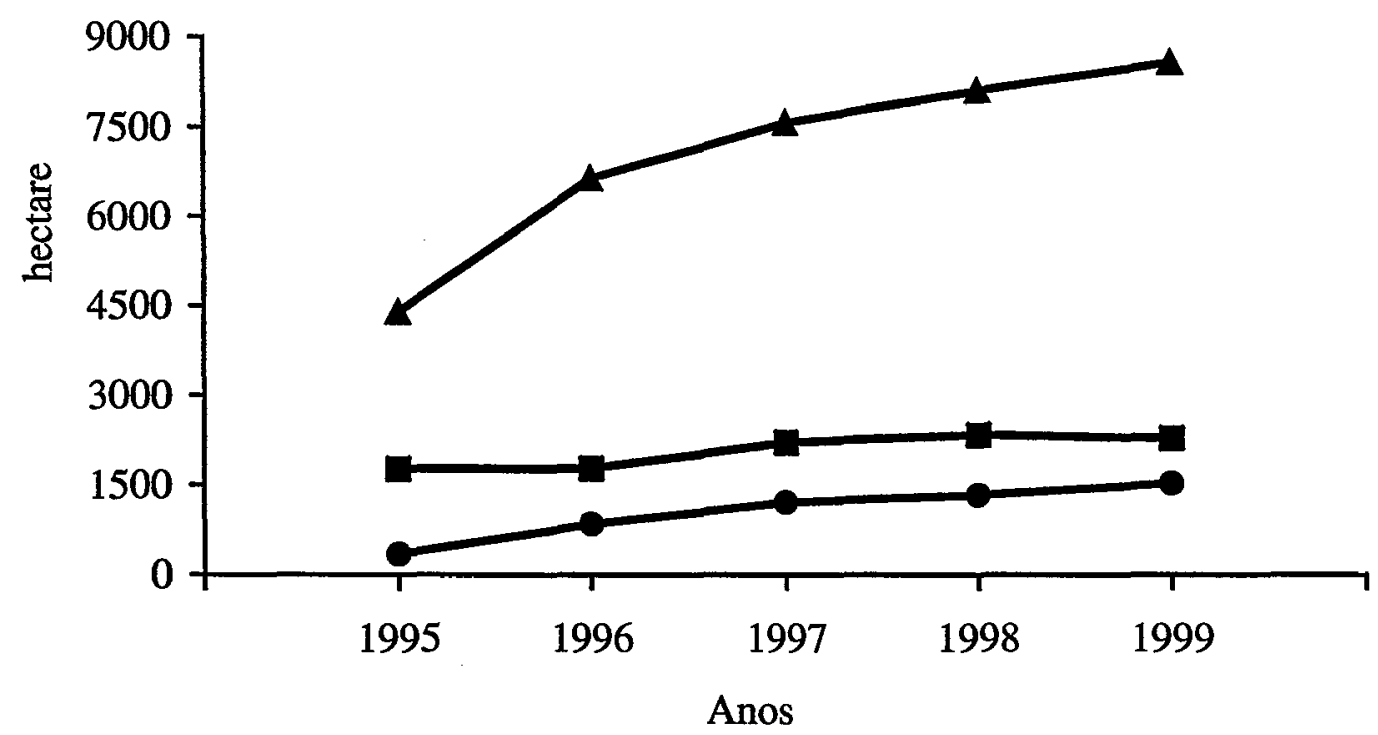

- Região Oeste $\rightarrow-$ Região Sudoeste $\rightarrow-$ Estado do Paraná

Figura 2 - Evolução da lâmina d'água destinada à piscicultura no Paraná e nas regiỏes Oeste e Sudoeste do Estado no período de 1995 a 1999.

Outro aspecto importante que explica o crescimento da piscicultura nestas regiões é a predominância de pequenas propriedades que empregam mão-de-obra familiar e que, normalmente, realizam diversas atividades no meio rural a fim de complementar a renda da propriedade. Além desses fatores, as condições climáticas também são bastante favoráveis aos cultivos apesar das baixas temperaturas verificadas durante o inverno.

Com relação ao número de piscicultores, no Estado do Paraná, observa-se que houve um crescimento anual médio de $9,59 \%$, no período entre 1995 e 1999 . O número de piscicultores paranaenses, em 1996, cresceu, em média, 37,94\%, em relação a 1995, mantendo-se estável a partir de 1997, conforme Tabela 10.

Essa diminuição do número de produtores de peixe, na região, pode ser explicada por duas razões. Uma delas é o fato desta região ter sido pioneira na prática da piscicultura, na década de 80, quando muito pouco se conhecia das tecnologias de produção. A partir dos anos 90, com a maior disponibilidade de informação e tecnologia, 
foi possível intensificar o uso de alguns fatores e melhorar o desempenho da atividade. Desta forma, os produtores que não implementaram as novas técnicas na produção, especialmente o uso de ração balanceada, não conseguiram melhorar a qualidade do pescado para atender às exigências da indústria e dos pesque-pagues nem aumentar a produtividade sendo obrigados a abandonar a atividade piscícola.

Tabela 10. Evolução do número de piscicultores no Estado do Paraná no período de 1995 a 1999

\begin{tabular}{|c|c|c|c|c|c|c|c|c|c|c|}
\hline Região & 1995 & $\begin{array}{c}\text { Var. } \\
\%\end{array}$ & 1996 & Var.\% & 1997 & Var.\% & 1998 & Var. \% & 1999 & $\begin{array}{c}\text { Var. } \\
\%\end{array}$ \\
\hline Paranaguá & 114 & - & 126 & 10,5 & 184 & 46,0 & 138 & $-25,0$ & 86 & $-37,7$ \\
\hline Curitiba & 1140 & - & 1399 & 22,7 & 1359 & $-2,8$ & 1.544 & 13,6 & 1670 & 8,2 \\
\hline União da Vitória & 313 & - & 1583 & 405,7 & 1765 & 11,5 & 1.537 & $-12,9$ & 1435 & $-6,6$ \\
\hline Ponta Grossa & 1450 & - & 1983 & 36,7 & 1093 & $-44,8$ & 1.464 & 33,9 & 1365 & $-6,7$ \\
\hline Guarapuava & 615 & - & 1170 & 90,2 & 445 & $-61,9$ & 1.005 & 125,8 & 885 & $-11,9$ \\
\hline Irati & 480 & - & 940 & 95,8 & 1873 & 99,2 & 1.253 & $-33,1$ & 1304 & 4,7 \\
\hline Lapa & 658 & - & 750 & 13,9 & 750 & - & 1.017 & 35,6 & 975 & $-4,2$ \\
\hline Umuarama & 461 & - & 311 & $-32,5$ & 218 & $-29,6$ & 322 & 47,7 & 268 & $-16,2$ \\
\hline Campo Mourão & 705 & - & 1301 & 84,5 & 841 & $-35,3$ & 840 & $-0,1$ & 735 & $-12,5$ \\
\hline Apucarana & 495 & - & 207 & $-58,2$ & 205 & -0.9 & 121 & $-40,9$ & 218 & 80,2 \\
\hline Paranavaí & 180 & - & 78 & $-56,6$ & 56 & $-28,2$ & 78 & 39,3 & 79 & 1,3 \\
\hline Maringá & 209 & - & 331 & 58,4 & 283 & $-14,5$ & 298 & 5,3 & 286 & $-4,0$ \\
\hline Ivaiporã & 991 & - & 755 & $-23,8$ & 807 & 6,8 & 878 & 8,8 & 865 & $-1,5$ \\
\hline Londrina & 136 & - & 144 & 5,8 & 153 & 6,2 & 167 & 9,2 & 158 & $-5,4$ \\
\hline Cornélio Procópio & 715 & - & 481 & $-32,7$ & 414 & $-13,9$ & 528 & 27,5 & 536 & 1,5 \\
\hline Sto A. da Platina & 620 & - & 614 & $-0,9$ & 449 & $-26,8$ & 772 & 71,9 & 720 & $-6,7$ \\
\hline Pato Branco & 1118 & - & 2369 & 111,8 & 2199 & $-7,2$ & 2.409 & 9,5 & 2580 & 7,1 \\
\hline Francisco Beltrão & 1045 & - & 2389 & 128,6 & 2913 & 21,9 & 2.974 & 2,1 & 2934 & $-1,3$ \\
\hline Cascavel & 2243 & - & 2900 & 29,3 & 3065 & 5,7 & 2.970 & $-3,1$ & 2978 & 0,3 \\
\hline Toledo & 2218 & - & 2109 & $-4,9$ & 1745 & $-17,3$ & 1.731 & $-0,8$ & 1893 & 9,4 \\
\hline TOTAL & 15906 & - & 21940 & 37,9 & 20817 & $-5,1$ & 22.046 & 5,9 & 21970 & $-0,3$ \\
\hline
\end{tabular}

Fonte: EMATER-Parana, (1999). 


\subsubsection{Setor de beneficiamento e ou processamento}

O setor de transformação, por sua vez, é o terceiro elo do complexo produtivo agroindustrial que se encarrega de beneficiar e ou processar o pescado, alterando sua apresentação física e sua estrutura química, de modo a atender às necessidades do mercado consumidor e possibilitar as melhores condições de conservação do produto.

Não existem registros e estatísticas sobre a indústria de beneficiamento de tilápias paranaense. A realização deste trabalho implicará na coleta e ordenamento dados e informações sobre todas as empresas do ramo que operam no Paraná, sua localização, seus mercados e seu desempenho, de forma a caracterizar este segmento da cadeia produtiva da piscicultura estadual.

\subsubsection{Setor de distribuição e mercado consumidor}

O pescado produzido no Estado do Paraná é comercializado pelas unidades de beneficiamento na forma de filés junto a empresas varejistas e atacadistas ou, então, é vendido pelos próprios produtores aos compradores e transportadores de peixe vivo que, posteriormente, o comercializam nos pesque-pagues regionais e de outros estados.

A partir da década de 90, aproveitando-se da infra-estrutura de produção de pescado começaram a surgir os pesque-pagues como uma nova opção de comercialização de peixes. Observa-se que este setor tem se expandido continuamente nas diversas regiões do Estado desde então, passando a desempenhar um importante papel na distribuição, inclusive em outros estados brasileiros, do pescado aqui cultivado (Tabela 11). Cabe lembrar também que, enquanto a indústria estadual estava, até o ano 2000, legalmente impedida de comercializar o filé de tilápia fora do Paraná, praticamente não existiam restrições à comercialização do peixe vivo. 
Tabela 11. Número de pesque-pagues e a quantidade de peixe comercializada no Paraná no período de 1997 a 1999.

\begin{tabular}{lccc}
\hline \multicolumn{1}{c}{ Região } & \multicolumn{3}{c}{ Número de pesque-pagues } \\
\cline { 2 - 4 } & 1997 & 1998 & 1999 \\
\hline Paranaguá & 15 & 13 & 10 \\
Curitiba & 90 & 112 & 103 \\
União da Vitória & 9 & 7 & 8 \\
Ponta Grossa & 29 & 35 & 45 \\
Guarapuava & 14 & 19 & 28 \\
Irati & 12 & 14 & 16 \\
Lapa & 14 & 18 & 15 \\
Ivaiporã & 18 & 18 & 14 \\
Umuarama & 36 & 39 & 31 \\
Paranavaí & 15 & 15 & 15 \\
Maringá & 42 & 51 & 44 \\
Londrina & 29 & 37 & 35 \\
Cornélio Procópio & 19 & 20 & 24 \\
Sto Antônio da Platina & 37 & 41 & 39 \\
Campo Mourão & 44 & 36 & 51 \\
Apucarana & 23 & 24 & 19 \\
Pato Branco & 15 & 13 & 15 \\
Francisco Beltrão & 18 & 23 & 27 \\
Cascavel & 50 & 49 & 57 \\
Toledo & 36 & 34 & 28 \\
Total de Estabelecimentos & 565 & 618 & \\
Estimativa & 4.029 & 4.535 & \\
comercializado (t/ano) & & & \\
\hline & volume & & \\
\hline
\end{tabular}

Fonte: EMATER-Paraná (1999)

No que diz respeito ao destino dado à produção, constata-se que, em 1997, em média, $56 \%$ do pescado produzido pela piscicultura paranaense foi comercializado junto aos pesque-pagues no Paraná e em outros estados, $10 \%$ foi comercializado em feiras livres, $10 \%$ foi vendido na propriedade, $8 \%$ da produção destinou-se às indústrias e $26 \%$ desta atendeu ao consumo na propriedade e ou foi vendida diretamente aos consumidores finais por outros canais de comercialização (Tabela 12). 
Tabela 12. Principais canais de comercialização do pescado produzido em cativeiro no Estado do Paraná, nos anos de 1997 e 1999.

\begin{tabular}{lcccccccc}
\hline Microrregiões & \multicolumn{2}{c}{$\begin{array}{c}\text { Pesque-pagues } \\
\text { (\%) }\end{array}$} & \multicolumn{2}{c}{$\begin{array}{c}\text { Indústrias } \\
(\%)\end{array}$} & \multicolumn{2}{c}{$\begin{array}{c}\text { Feiras Livres } \\
(\%)\end{array}$} & \multicolumn{2}{c}{$\begin{array}{c}\text { Direto ao } \\
\text { Consumidor (\%) }\end{array}$} \\
\cline { 2 - 9 } & 1997 & 1999 & 1997 & 1999 & 1997 & 1999 & 1997 & 1999 \\
\hline Guarapuava & 20 & 17 & - & 3 & 10 & 13 & 70 & 66 \\
Curitiba & 10 & 81 & - & - & 60 & 9 & 30 & 10 \\
Paranaguá & 40 & 79 & - & 0,2 & - & - & 60 & 20,4 \\
U. Vitória & 40 & 19 & - & - & 30 & 24 & 30 & 58 \\
P. Grossa & 16,5 & 44 & - & - & 2,8 & 20 & 72,2 & 36 \\
Irati & 84 & 61 & - & - & 10 & 10 & 6 & 29 \\
Lapa & 10 & 60 & - & - & 5 & 2 & 85 & 38 \\
Média & 31,5 & 51,6 & - & 0,5 & 16,8 & 11 & 50,46 & 36,8 \\
Ivaiporã & 52,24 & 72 & - & 1,5 & 11,46 & 6 & 36,1 & 20,5 \\
Umuarama & 83,5 & 65 & 2 & 10 & & 3 & 9 & 22 \\
Paranavaí & 97,5 & 87 & - & - & - & 0,5 & 2,5 & 12,5 \\
Maringá & 95 & 85 & - & 2 & 3,0 & 4 & 2 & 9 \\
Londrina & 80 & 92 & 6 & - & 10,0 & 0,7 & 4 & 7 \\
C. Procópio & 95 & 98 & - & - & 1,0 & 0,3 & 4 & 1,7 \\
S. A. Platina & 75 & 70 & 10 & 0,3 & 4,0 & 4 & 21 & 26 \\
C. Mourão & 70 & 72 & - & 8 & 10,0 & 1 & 10 & 1,9 \\
Apucarana & 60 & 88 & - & - & 20,0 & 2 & 20 & 10 \\
Média & 78,69 & 81 & 2,0 & 2,4 & 7 & 2,4 & 12,3 & 12,3 \\
Toledo & 47,50 & 64 & 50,0 & 31 & 0,5 & 1 & 2 & 4 \\
Cascavel & 66,50 & 55 & 28,0 & 34 & 3,0 & 4,5 & 2,5 & 6,5 \\
P. Branco & 25,50 & 54 & 25,0 & 27 & 10,4 & 6 & 39,1 & 13 \\
F. Beltrão & 48,50 & 42 & 33,0 & 15 & 6,1 & 3 & 12,4 & 40 \\
Média & 47 & 54 & 34 & 27 & 5 & 3,6 & 14 & 16 \\
Média Estadual & 56 & 65 & 8 & 7 & 10 & 5,65 & 26 & 22 \\
\hline
\end{tabular}

Fonte: EMATER-Paraná (1997) e EMATER-Paraná (1999).

Na microrregião de Toledo, cerca de $50 \%$ do pescado produzido foi comercializado junto à indústria que se encarregou da filetagem, embalagem e distribuição do produto junto aos canais atacadistas e varejistas e $47,5 \%$ desta produção destinou-se aos pesque-pagues. A microrregião de Cascavel, por possuir alguns municípios situados a um raio de, aproximadamente, $100 \mathrm{~km}$ de distância das indústrias do regional de Toledo teve cerca de $28 \%$ da sua produção comercializada junto às unidades de beneficiamento, predominando, entretanto, as vendas para pesque-pagues, que absorveram em torno de $66,5 \%$ da quantidade produzida (ver Tabela 12). 
A região Sudoeste comercializou $25 \%$ da sua produção junto à indústria. O restante da produção foi comercializada em pesque-pagues $(25,5 \%)$, em feiras livres $(10,4 \%)$ e cerca de $39,1 \%$ destinou-se ao consumo na propriedade e às vendas direto ao consumidor (Tabela 12).

Observa-se ainda que, em 1997, nas outras regiōes do Estado do Paraná, em média, $82 \%$ da produção foi vendida aos pesque-pagues e apenas $2 \%$ do peixe produzido foi comercializado junto à indústria (Tabela 12).

Desta forma, verifica-se que o Oeste do Paraná, foi a região que mais comercializou junto a inđústria, em 1997. Em média, 39\% da produção regional foi comprada pelas unidades de beneficiamento (Tabela 12), o que torna ainda mais evidente o importante papel das unidades de beneficiamento no desenvolvimento da piscicultura desta região.

No ano de 1999 , em média, $65 \%$ da produção estadual, em torno de 11.949 toneladas de peixe, foi comercializada através dos pesque-pagues, sendo que aproximadamente $47 \%$ deste total foi distribuída pelos 624 estabelecimentos instalados no estado. A indústria, no mesmo ano, comercializou, em média, $7 \%$ da produção piscícola estadual. Observa-se que, apesar de ter aumentado o número de unidades de beneficiamento em funcionamento no Paraná, a participação média da indústria na comercialização do peixe produzido diminuiu, enquanto cresceu o percentual da produção destinada aos pesque-pagues (Tabela 12).

Estes resultados se explicam pelos elevados preços pagos aos produtores pelos pesque-pagues que chegam a ser 3 a 5 vezes maiores do que os pagos pelas unidades de beneficiamento. Isso faz com que os produtores deixem de vender à indústria, estocando o peixe vivo, inclusive durante $o$ inverno quando os pesque-pagues não funcionam, a fim de obter preços maiores na entrada do verão, quando os estabelecimentos de pesque-pague do Paraná e de outros estados voltam à atividade.

Com relação à comercialização do filé de tilápia, o principal produto elaborado pela indústria, sabe-se que tem sido comercializado junto aos restaurantes, pesquepagues, hotéis e principalmente, supermercados. Os principais mercados consumidores 
são os municípios de Londrina, Maringá, Curitiba, Foz do Iguaçu e municípios da região, especialmente, Cascavel e Toledo.

O mercado consumidor de peixes é pouco conhecido no Brasil e no Paraná. A captura inconstante e, às vezes, escassa aliada as ações individuais das indústrias pesqueiras fizeram com que o mercado consumidor fosse pouco estimulado e conhecido. De acordo com Cyrino \& Grÿschek (1997), o consumo médio per capita anual de pescado no Brasil é cerca de $4,9 \mathrm{~kg}$, muito abaixo do consumo nos países como Japão (68 kg/ano), Portugal (36 kg/ano),Senegal (40kg/ano) ou Estados Unidos (7,5 kg/ano).

Entretanto, mediante uma oferta regular de produtos, com qualidade e preços estáveis, é possível mudar este quadro. Por exemplo, as principais regiões metropolitanas do país ainda representam um grande mercado a ser conquistado, uma vez que abrigam grandes contingentes populacionais e apresentam um elevado nível de segmentação do consumo.

O consumidor do interior paulista, com renda média elevada e de consumo sofisticado, também pode ser citado como um mercado potencial para peixe produzido no Estado do Paraná.

O mercado do interior paranaense, distante da faixa litorânea caracteriza-se pelo baixo consumo de pescado podendo, no entanto, ser expandido pois, além do consumo familiar, existem mercados crescentes e potenciais como refeições industriais e a merenda escolar (Libardi et al, 1996).

O ramo de refeições industriais prontas é um segmento da indústria alimentar que tem crescido em todo o Brasil. Segundo Libardi et al (1996), nas regiões metropolitanas de Curitiba, São Paulo, Porto Alegre, Belo Horizonte e Brasília, em 1996, foram servidas cerca de 1.530 .533 refeições industriais. Ainda, segundo o mesmo autor, em Curitiba, são servidas 150 gramas de peixe por pessoa em refeições industriais, uma vez por mês durante o inverno e duas vezes por semana durante o verão. Portanto, se o peixe fosse incluído no cardápio uma vez por mês, sendo fornecidos $150 \mathrm{~g}$ por refeição, teria-se um consumo de 3.671 toneladas de pescado por ano. No entanto, em condições mais favoráveis de oferta, sabe-se que não seria nenhum absurdo considerar a possibilidade de introduzir o peixe nos cardápios dos restaurantes 
industriais uma vez por semana. Isto representaria um consumo de 11.013 toneladas de pescado por ano.

A merenda escolar fornecida aos alunos do $1^{\circ}$ grau da rede pública é outro mercado a ser conquistado. A primeira experiência de inclusão de peixe na merenda escolar no Paraná foi observada, recentemente, no município de Toledo. Foi incluído peixe na merenda distribuída a 20 mil alunos, sob a forma de croquetes, uma vez por mês. Isto representou um consumo de 2 t/mês de peixe. De acordo com Libardi et al (1996), se todos os municípios do Estado incluíssem, uma vez por mês, o peixe na merenda escolar, este mercado absorveria 75 toneladas de peixe por mês.

Apesar do grande mercado potencial para o pescado cultivado em água doce, existem vários problemas que precisam ser superados pela indústria piscícola brasileira $\mathrm{e}$ paranaense. A produção, a industrialização e a distribuição do pescado ainda ocorrem de forma desconexa, comprometendo a qualidade do produto e elevando o preço do pescado em relação às fontes tradicionais de proteína. Além disso, a ação isolada das empresas dificulta a divulgação do produto e a consequiente mudança no hábito de consumo. Somado a tudo isto, têm-se produtos pouco processados e, portanto, pouco práticos.

\subsection{Legislação}

Paralelamente ao complexo produtivo da piscicultura encontra-se o ambiente organizacional e institucional que interferem no desempenho do setor. $\mathrm{O}$ ambiente organizacional é formado por instituições responsáveis pela fiscalização, pesquisa, crédito, fomento, orientação e assistência técnica. $\mathrm{O}$ ambiente institucional é constituído pelas entidades, geralmente governamentais, encarregadas de elaborar as leis e as normas que regulam o funcionamento do setor. Neste caso, pretende-se apresentar, resumidamente, as principais legislações que regulamentam a instalação e o funcionamento das unidades de beneficiamento de pescado cultivado. 
O Decreto Federal N 24643 de 10/07/34 conhecido como "Código de Águas", a Lei Estadual $\mathrm{N}^{\circ} 7109$ de 17/01/79, os Decretos Estaduais $\mathrm{N}^{\circ} 857$ de 18/07/79 e $\mathrm{N}^{\circ}$ 4141 de 11/11/88 dispõem sobre o uso e derivação da águas de domínio público, e a Portaria $\mathrm{N}^{\circ}$ 020/96 da Superintendência de Desenvolvimento de Recursos Hídricos e Saneamento Ambiental (SUDERHSA) torna obrigatória a outorga ${ }^{7}$ de concessão e autorização para uso das águas de domínio público no Estado do Paraná (Paraná, 1996).

De acordo com esta legislação, passa a ser pré-requisito para a instalação de unidades de beneficiamento ou processamento de pescado de água doce criado em cativeiro a autorização administrativa para usar os recursos hídricos de domínio público para utilidade privada. As autorizações são outorgadas pelo prazo máximo de 5 anos, podendo ser renovadas, bem como revogadas a qualquer tempo, independentemente de indenização, desde que o interesse público o exija.

A Portaria No 020/96 especifica que a SUDERHSA é responsável pela fiscalização do cumprimento das exigências legais, bem como pela aplicação das sanções quando a lei não for cumprida (Paraná, 1996).

Quanto à legislação brasileira e estadual que regulamenta a produção e a comercialização de pescado benefíciado ou processado, tem-se a Lei Federal No 7889 de 23/11/1989 que torna obrigatória a inspeção sanitária e industrial de todos estabelecimentos industriais e entrepostos dos produtos de origem animal. Em 24/05/1994 é sancionada a Lei Estadual No 10799 que cria o Serviço de Inspeção Estadual/Paraná e determina suas atribuições (Paraná, 1999a).

O Decreto $N^{\circ} 4210$ de 01/11/1994 torna obrigatória a prévia inspeção sanitária e industrial de todos os produtos de origem animal, comestíveis e não comestíveis, em todo o Território Estadual e a Resolução $n^{\circ}$ 203/94 da Secretária de Estado da Agricultura e do Abastecimento aprova a Regulamentação da Inspeção Sanitária e Industrial de Pescados e seus Derivados que estatui as normas que regulam o registro dos estabelecimentos que produzem matéria-prima, manipulam, industrializam, embalam, distribuem e comercializam pescados e derivados. De acordo com a legislação

\footnotetext{
${ }^{7}$ A Outorga é um ato administrativo, no qual o poder público consente que pessoas físicas e jurídicas façam uso dos recursos hídricos de domínio público mediante condições por ele determinadas.
} 
citada, as empresas que se dedicam ao beneficiamento e ou processamento de pescado e derivados são obrigadas ao registro junto ao Serviço de Inspeção Municipal se comercializarem apenas no território municipal, junto ao Serviço de Inspeção Estadual (SIP/POA) para realizarem o comércio intermunicipal em trritório paranaense, e junto ao Serviço de Inspeção Federal (SIF/POA) no caso de comercializarem no mercado nacional e externo, sendo exigida a presença permanente de um responsável técnico de nível superior, legalmente habilitado em qualquer um dos casos (Paraná, 1999b).

A Instrução Normativa $N^{\circ}$ 003/98 de 06/06/1998 determina as normas técnicas para os estabelecimentos que manipulam, beneficiam, processam, embalam, conservam e distribuem pescados e derivados, quanto às instalações, localização e condições básicas de funcionamento (Paraná, 1999b).

Outra legislação que tem impacto sobre a indústria de beneficiamento de pescado é o Decreto $N^{\circ} 4.621$ de 27/07/98 da Secretaria de Estado da Fazenda, que estabelece a redução da base de cálculo do ICMS, em substituição ao regime normal de tributação, nas operações internas com produtos da Cesta Básica (Paraná, 1998).

No caso de pães, peixes frescos, resfriados ou congelados, a base de cálculo do ICMS fica reduzida para $58,333 \%$. Desta forma, a alíquota para as operações com pescado fresco, resfriado ou congelado, antes de $12 \%$, passa a ser de $7 \%$.

Ainda de acordo com o mesmo Decreto da Secretaria de Estado da Fazenda, a base de cálculo do ICMS fica reduzida para $40 \%$ nas operações realizadas com ração para animais, concentrados e suplementos industrializados e devidamente registrados junto ao Ministério da Agricultura, até 30/04/2001. Este benefício outorgado à saída de produtos destinados à pecuária estende-se às remessas com destino à apicultura, aqüicultura, avicultura, cunicultura, ranicultura e sericultura. Neste caso, o piscicultor é beneficiado por uma redução de $7,2 \%$ do ICMS na compra da ração, sendo prorrogável para os próximos anos. 


\section{REVISÃO DE LITERATURA}

Neste capítulo serão analisadas as formulações teóricas consideradas mais importantes para caracterizar a organização da indústria de beneficiamento de tilápia-donilo instalada no Paraná.

Optou-se por trabalhar, neste estudo, com o paradigma estrutura-condutadesempenho, que permite fazer uma análise descritiva e global de como as firmas se organizam e se inter-relacionam no intuito de desempenhar eficientemente suas funções no mercado.

Por esta razão, apresenta-se no item 3.1. uma revisão do paradigma estruturaconduta-desempenho. Também, serão feitas algumas considerações sobre as estruturas de mercado (item 3.2.) e suas relações com a conduta das firmas (item 3.3).

\subsection{O paradigma estrutura-conduta-desempenho}

Segundo o paradigma estrutura-conduta-desempenho, os bons resultados e o sucesso de uma indústria depende da conduta dos compradores e vendedores que, por sua vez, decorre da estrutura da indústria.

Segundo Koch (1980), a estrutura de mercado refere-se aos elementos que caracterizam a organização de um mercado e que podem interferir estrategicamente na natureza da competição e dos preços deste mercado.

De acordo com Barros (1987) e Marques \& Aguiar (1993), as principais características levadas em consideração para identificar a estrutura de um mercado são a 
existência ou ausência de barreiras à entrada e à saída de empresas, o grau de diferenciação física ou subjetiva que prevalece entre produtos concorrentes e o grau de concentração de vendedores e compradores no mercado relevante. Também podem ser citados como aspectos importantes nesta análise a estrutura de custos de uma firma, o grau de integração vertical entre a produção e a distribuição do produto final bem como a economia de escala da indústria.

Os produtos podem ser diferenciados pela marca, pelas condições de venda ou por ambas. A diferenciação dos produtos afeta a preferência dos compradores mudando a inclinação da curva de demanda. Por exemplo, se a demanda for pouco sensível às variações nos preços, os vendedores terão pouco incentivo para reduzir o preço do produto.

As barreiras à entrada de novas empresas no mercado referem-se a fatores que beneficiam atacadistas e outros participantes do mercado, impossibilitando ou dificultando a entrada de novos possíveis concorrentes que ameacem os lucros e a participação de mercado das empresas já estabelecidas. As barreiras à entrada de novas empresas no mercado podem assumir várias formas como escalas, experiência, tecnologias, crédito e produtos diferenciados. Por exemplo, a economia de escala constitui-se em uma barreira à entrada de novas empresas no mercado quando firmas não podem reduzir os seus custos sem antes crescer e aumentar sua participação no mercado. Outras barreiras à entrada ocorrem quando novas firmas não podem competir devido às vantagens em experiência e capacidade empresarial das firmas já estabelecidas ou ainda devido à fidelidade dos consumidores, aos produtos diferenciados, fontes de crédito e promoções de venda.

Como decorrência da estrutura do mercado tem-se a conduta das empresas estabelecidas neste mercado que pode ser definida, segundo Barros (1987), como os padrões de comportamento das firmas nos mercados em que operam. As características relevantes a serem consideradas ao analisar a conduta de uma determinada firma no mercado em que atua são os métodos empregados na determinação da escala de produção e dos respectivos preços, medidas adotadas no sentido de aprimorar o produto, estratégias de marketing, principalmente aquelas voltadas à divulgação do produto e à 
promoção de vendas, formas utilizadas para ajustar-se à produção, aos preços e políticas de marketing das empresas concorrentes, mecanismos utilizados para impedir ou dificultar a entrada de novos concorrentes no mercado.

De acordo com Shang (1990), os fatores que caracterizam a conduta do mercado de pescado são as políticas de preços e a interação entre vendedores e compradores participantes do mercado via coordenação e integração das atividades.

A estrutura e a conduta também podem ser influenciadas por várias condições de oferta, de demanda e por políticas governamentais existentes. As condições básicas de oferta que normalmente interferem na forma como se estruturam e se comportam as firmas em um dado mercado são, entre outras, a localização e o acesso às matériasprimas essenciais, o tipo de tecnologia disponível e a perecibilidade do produto. Já as principais condições de demanda capazes de influenciar a estrutura e a conduta de mercado são a elasticidade-preço da demanda, a taxa de crescimento da demanda, a disponibilidade de produtos substitutos e sazonalidade da demanda. As políticas governamentais também influenciam a estrutura, a conduta e o desempenho de uma indústria da mesma forma que a conduta da indústria pode influenciar as políticas governamentais (Carlton \& Perloff, 1991).

Conforme destacado anteriormente, o desempenho de mercado de uma indústria dependerá da conduta das firmas neste mercado. A principal preocupação em relação ao desempenho de mercado é a eficiência que, de acordo com a Teoria Microeconômica, indica o sucesso de uma indústria ou firma em maximizar a sua produção ou minimizar seus custos empregando a combinação mais rentável possível de recursos. Barros (1987) vai além e define eficiência de mercado como os resultados econômicos decorrentes do funcionamento de uma indústria ou firma em termos de preços em relação aos custos médios, escala de produção versus tamanho ótimo, variedade e qualidade do produto, grau de receptividade das firmas às inovações e ao progresso tecnológico e gastos com marketing de vendas. 


\subsection{As estruturas de mercado}

Antes de discutir as estruturas de mercado propriamente ditas, é conveniente definir o significado de competição na análise econômica.

$\mathrm{Na}$ teoria econômica moderna, uma indústria é dita puramente competitiva quando o número de empresas vendendo determinado produto homogêneo é tão grande e a parcela individual de mercado de cada firma é tão pequena (elementos estruturais) que nenhuma firma individualmente é capaz de influenciar significativamente o preço do produto no mercado variando a quantidade ofertada (elemento de conduta).

Do ponto de vista do comprador, pode ser dada uma definição simétrica, onde a competição pura ${ }^{8}$ existe entre compradores quando o número de agentes comprando um determinado produto é tão grande e a fatia de mercado de cada um é tão pequena que cada comprador acredita que a quantidade que ele compra tem um efeito imperceptível nos preços de mercado (ver Scherer, 1970). Contudo, as imperfeições existentes no modelo de competição pura dão origem a uma série de tipos de estruturas de mercado.

De acordo com Scherer (1970, p.10), existem 5 tipos principais de estruturas de mercado vendedor, baseados no número de vendedores e na natureza do produto, conforme o quadro 1.

Os produtos são chamados de homogêneos quando os compradores os consideram substitutos perfeitos entre si. Quando um produto, a um dado preço, é preferido ao produto concorrente, pelos menos por alguns compradores, seja por seus atributos físicos, ou pela sua imagem subjetiva, ou ainda pelos serviços oferecidos pelo vendedor, diz-se que os produtos são diferenciados.

${ }^{8}$ É importante lembrar a diferença existente entre a definição de competição descrita acima e a competição entre as empresas que vendem produtos similares e disputam permanentemente o mesmo mercado. O termo competição aqui empregado caracteriza o tipo de mercado acima definido; para caracterizar a conduta da empresas empregar-se-á o termo "rivalidade". 


\begin{tabular}{|l|ccc|}
\hline $\begin{array}{r}\text { Número de } \\
\text { Vendedores }\end{array}$ & Um vendedor & Alguns vendedores & $\begin{array}{c}\text { Muitos } \\
\text { vendedores } \\
\text { Produto }\end{array}$ \\
\hline Produto Homogêneo & Monopólio Puro & $\begin{array}{c}\text { Oligopólio } \\
\text { Homogêneo }\end{array}$ & Competição pura \\
Produto Diferenciado & Monopólio Puro & $\begin{array}{c}\text { Oligopólio } \\
\text { Diferenciado }\end{array}$ & $\begin{array}{c}\text { Competição } \\
\text { Monopolística }\end{array}$ \\
\hline
\end{tabular}

Quadro 1 - Estruturas de mercado baseadas no número de vendedores e na natureza do produto segundo Scherer (1970)

Com relação ao número de vendedores, embora não seja difícil distinguir um monopólio puro de um oligopólio, a distinção entre uma estrutura oligopolística e uma competitiva é mais subjetiva. Em um mercado oligopolista tem-se um número de vendedores suficientemente pequeno para que cada vendedor acredite que suas ações individuais afetam as outras empresas, da mesma forma que a conduta das outras empresas afetam seu desempenho econômico. Já em uma estrutura competitiva existem muitos vendedores que não são capazes de alterar o mercado com suas ações individuais.

Ainda, segundo Scherer (1970), tanto monopolistas puros quanto oligopolistas e competidores monopolistas reconhecem que suas decisões sobre a produção afetam os preços do mercado, ou seja, os três possuem algum grau de poder sobre os preços e este poder depende do tamanho relativo da firma em relação ao mercado. $O$ mesmo autor salienta que as barreiras à entrada de novas empresas são condições essenciais para a existência de monopólio ou oligopólio.

Carlton \& Perloff (1991), por sua vez, apresentam uma classificação de estruturas de mercado baseada no número de vendedores e compradores e na existência ou ausência de barreiras à entrada de novas empresas no mercado (ver no quadro 2).

A classificação proposta por Carlton \& Perloff (1991) tem a vantagem de incluir este importante fator determinante das estruturas de mercado que é a presença ou ausência de barreiras à entrada de novas empresas. Cabe destacar que a homogeneidade 
ou diferenciação do produto considerados por Scherer (1970) também está compreendidos no conceito de barreiras à entrada.

Ainda de acordo com o mesmo autor, quando os vendedores, mesmo com a concorrência de outras firmas, são capazes de influenciar os preços tem-se um oligopólio ou uma competição monopolística. Neste caso, o que diferencia uma estrutura da outra, é a existência ou a ausência de barreiras à entrada. É um oligopólio se existirem barreiras à entrada de novos vendedores no mercado. Se não existirem barreiras à entrada tem-se uma competição monopolística.

\begin{tabular}{|l|cccc|}
\hline Estruturas de Mercado & $\begin{array}{c}\text { Barreiras à entrada } \\
\text { de vendedores }\end{array}$ & $\begin{array}{c}\text { Número de } \\
\text { Vendedores }\end{array}$ & $\begin{array}{c}\text { Barreiras à entrada } \\
\text { de compradores }\end{array}$ & $\begin{array}{c}\text { Número de } \\
\text { Comprador } \\
\text { es }\end{array}$ \\
\hline Competição & Não & Muitos & Não & Muitos \\
Monopólio & Sim & Um & Não & Muitos \\
Monopsônio & Não & Muitos & Sim & Um \\
Monopólio bilateral & Sim & Um & Sim & Um \\
Oligopólio & Sim & Poucos & Não & Muitos \\
Oligopsônio & Não & Muitos & Sim & Poucos \\
Competição monopolística & Poucas* & Muitos & Não & Muitos \\
\hline
\end{tabular}

Quadro 2 - Estruturas de mercado baseadas no número de vendedores e compradores e nas barreiras à entrada segundo Carlton \& Perloff (1991)

* Alterado em relação ao original, no que se lê: não, de acordo com Moraes (1996).

Guimarães (1981) também apresentou uma proposta de classificação das diferentes estruturas de mercado levando em consideração que a diferenciação do produto pode viabilizar um novo padrão de competição entre as empresas (Quadro 3).

Este autor propôs uma classificação que, ao invés de basear-se apenas na competição via preço, considera a possibilidade de combinação dos mecanismos de competição via preço e extra-preço (diferenciação do produto). 
A competição via diferenciação do produto pode tornar-se mais eficiente do que a competição por preço, se for levado em consideração que uma redução no preço (a fim de aumentar a parcela de mercado) pode ser acompanhada pelos concorrentes, chegando, algumas vezes, a anular o efeito esperado, enquanto nem todos os concorrentes conseguem imitar um produto diferenciado, proporcionando à firma uma vantagem sobre os concorrentes.

A partir desta análise, Guimarães (1981) classificou a indústria em quatro tipos: a indústria competitiva onde existe apenas a competição via preço; a indústria competitiva diferenciada, na qual existe a competição por preço e por diferenciação do produto; o oligopólio diferenciado quando existe apenas competição por diferenciação do produto e não via preço e a indústria oligopolista pura (oligopólio homogêneo) quando não ocorre competição nem via preço nem por diferenciação do produto. A classificação das estruturas de mercado, segundo Guimarães (1981), está resumida no quadro 3.

\begin{tabular}{|l|c|c|}
\hline $\begin{array}{r}\text { Tipo de } \\
\text { Tipo de } \\
\text { Indústria }\end{array}$ & Competição & $\begin{array}{c}\text { Competição por } \\
\text { Cõão por preço } \\
\text { diferenciação do produto }\end{array}$ \\
\hline Competitiva & Existe & não existe \\
\hline Competitiva diferenciada & Existe & existe \\
\hline Oligopolista diferenciada & não existe & existe \\
\hline Oligopolista pura & não existe & não existe \\
\hline
\end{tabular}

Quadro 3 - Tipos de indústria baseados na competição via preço e na competição por diferenciação do produto segundo Guimarães (1981)

Desta forma, a preferência do consumidor por determinado produto diferenciado pode se constituir em uma barreira à entrada de novas empresas no mercado, já que nem todas as empresas estão aptas a fazer a diferenciação do produto. 
Dentre as classificações das diferentes estruturas de mercado discutidas, optouse pela classificação proposta por Carlton \& Perloff (1991), por abranger tanto o mercado vendedor quanto comprador e por levar em consideração como fator determinante das estruturas de mercado a existência ou não de barreira à entrada.

\subsection{A estrutura de mercado e a conduta das empresas}

Neste item procura-se discutir como as estruturas de mercado influenciam a conduta das empresas.

Num mercado competitivo as empresas são tomadoras de preços e os problemas econômicos são resolvidos pela interação das forças de oferta e demanda do produto $e$ não por entidades privadas e governamentais. Além disso, a ausência de barreiras à entrada no mercado permite a liberdade de oportunidade e a livre mobilidade dos recursos, já que os indivíduos são livres para escolher em qual ramo de atividade desejam trabalhar, bem como para se deslocar de um setor para outro sempre que surgirem oportunidades mais lucrativas.

No outro extremo, estão os monopolistas, que por serem únicos no mercado e por existirem barreiras que dificultam a entrada de novas empresas, quando os lucros forem positivos no longo prazo, possuem poder de mercado e, portanto, podem fixar os preços acima do nível de mercado competitivo. Da mesma forma, os monopsonistas (únicos compradores) também possuem poder para fixar os preços abaixo daqueles praticados em uma economia competitiva. Naturalmente, esta é uma conduta indesejável para a sociedade.

Em estruturas oligopolistas, com poucas firmas, também pode ocorrer uma conduta monopolista. De acordo com Scherer (1979), quando a concentração do mercado é alta, as decisões de preços dos vendedores são interdependentes e as firmas envolvidas reconhecem sua mútua interdependência. Esta consciência faz com que, muitas vezes, as poucas empresas existentes, para maximizar seus lucros, adotem 
políticas cooperativas com a relação à fixação de preços formando uma espécie de "cartel".

As decisões sobre preços, visando atingir o máximo lucro, podem ser tomadas pelas empresas existentes combinando preços e quantidades ou com as firmas menores seguindo o preço fixado pela líder (que pode ser a mais tradicional, a mais antiga ou a mais conhecida), que fixa seus preços a partir dos seus custos totais. As firmas seguidoras, podem não conseguir os elevados lucros como no monopólio, mas certamente obtêm lucros bem maiores do que se estivessem em um mercado competitivo.

Quando não existe uma coalisão entre as empresas oligopolistas, ou ainda, quando as demais empresas não estão dispostas a seguir a líder, observa-se uma tendência de rigidez do preços, que pode ser explicada pela curva de demanda quebrada. Resumidamente, a rigidez dos preços ocorre pois o empresário oligopolista acredita que seus concorrentes irão reagir às suas estratégias, anulando seus esforços. Em outras palavras, se ele reduzir o preço, com o objetivo de aumentar suas vendas, seus rivais também o farão; se, por sua vez, ele aumentar os seus preços as firmas concorrentes não farão o mesmo, roubando-lhe parcelas de mercado, (Scherer, 1979).

Desta forma, segundo Ferguson (1992), o preço no oligopólio tende a ser bastante rígido, mudando raramente e apenas quando ocorrerem mudanças muito significativas nos custos. Logo, em mercados oligopolistas são utilizadas as formas alternativas de concorrência, também conhecida como concorrência extra-preço. Embora sejam muitos os meios de diferenciação do produto, pode-se citar alguns dos mais empregados pelas firmas, tais como propaganda do produto e da marca, diferenciais de qualidade, serviços de atendimento ao consumidor e designs (desenhos, cores, embalagens, formas).

Apesar de não se ter conhecimento de muitos outros trabalhos sobre a cadeia produtiva de pescado realizados sob a ótica da teoria da Organização Industrial, considerou-se o paradigma estrutura-conduta-desempenho adequado, pois sabe-se da existência de trabalhos bem sucedidos que utilizaram esta abordagem teórica (ver Aguiar, 1994; Moraes, 1996). 


\section{METODOLOGIA}

\section{1 Área de estudo}

Este trabalho foi realizado no Estado do Paraná, levando em consideração a produção piscícola dos 399 municípios do Estado do Paraná divididos em vinte núcleos administrativos regionais da EMATER-Paraná, que foram agrupados em cinco regiões:

a) Sul é formada por sete microrregiões ou coordenações regionais da EMATER-Paraná: Paranaguá, Curitiba, União da Vitória, Ponta Grossa, Guarapuava, Irati e Lapa;

b) Norte composta por seis microrregiões: Apucarana, Paranavaí, Maringá, Londrina, Cornélio Procópio e Santo Antônio da Platina;

c) Noroeste é formada por três sedes regionais tais como, Umuarama e Campo Mourão;

d) Oeste constituída por dois núcleos regionais: Toledo e Cascavel;

e) Sudoeste formada de duas sedes regionais: Pato Branco e Francisco Beltrão.

A piscicultura é praticada, atualmente, em todo o Estado do Paraná, no entanto, as diferentes regiões apresentam diversos níveis de desenvolvimento e organização da atividade, motivo que justifica a agregação acima proposta. 


\subsection{Fonte e natureza dos dados}

Este estudo teve como objetivo analisar a organização industrial das unidades de beneficiamento de tilápias-do-nilo instaladas no Estado do Paraná.

Para caracterizar a indústria de beneficiamento de tilápias, quanto a sua estrutura de mercado, conduta empresarial e desempenho foram entrevistadas as vinte empresas instaladas e que estavam operando no ano de 2.000. Inicialmente foram feitos contatos por telefone para solicitar as informações. No caso das seis empresas instaladas no Extremo Oeste do Paraná (nas regiões de Toledo e Cascavel) foram marcadas visitas para a realização das entrevistas. Estas empresas foram visitadas no período de 11 a 22 de dezembro de 2000. Com relação às empresas localizadas nas outras regiões do Estado foram aplicados os questionários por telefone ( ver Apêndice 1), no período de 3 a 12 de janeiro de 2001. Apenas duas empresas localizadas na região Sudoeste responderam apenas a parte das questões, alegando se tratarem de questões estratégicas para a empresa. No entanto, algumas informações complementares referentes a estas duas empresas (tais como número de trabalhadores, capacidade instalada, horas semanais de trabalho) foram obtidas através dos extensionistas da prefeitura e da EMATER-Paraná e junto ao Departamento de Inspeção Sanitária da Secretaria do Estado da Agricultura e do Abastecimento.

Nas análises da conduta empresarial e do desempenho da referida indústria foram utilizados dados obtidos através das entrevistas realizadas, junto às vinte empresas estabelecidas no ano de 2000 . No que diz respeito à conduta das empresas procurou-se identificar as principais estratégias competitivas e o grau de rivalidade existente na indústria. Quanto ao seu desempenho, procurou-se avaliar alguns indicadores do desenvolvimento e a eficiência econômica com que a referida indústria tem operado no mercado paranaense.

Para caracterizar a estrutura deste mercado foi necessário diagnosticar a produção total ofertada no mercado paranaense, não apenas a produção total das empresas oficialmente instaladas, mas também a produção artesanal de filé realizada por produtores e ou por pesque-pagues, em todas as regiões do Estado, e não sujeitos ao 
controle e a fiscalização do Serviço de Inspeção Sanitária bem como, o volume total de filé de tilápia proveniente de outros estados brasileiros.

Os dados sobre o filé de tilápia produzido em outros Estados e comercializado no Paraná, em 1999, foram obtidos a partir de entrevista, via telefone, junto à única empresa que ofertou filé no referido no período.

Os dados sobre a produção artesanal de filé de tilápia no Paraná foram levantados mediante contatos telefônicos com os extensionistas rurais dos escritórios municipais da EMATER-Paraná, no período de 16 de agosto de 2000 a 31 de janeiro de 2001. Esta produção foi estimada pelos extensionistas com base nos dados da produção estadual e regional da safra 1998/1999, uma vez que as estatísticas da safra 1999/2000 ainda não haviam sido coletadas e elaboradas. Desta forma, para que a produção artesanal, industrial e proveniente de outros estados pudessem ser comparadas e calculadas as respectivas parcelas de mercado de cada empresa, a análise da estrutura de mercado foi realizada considerando a produção das dezoito empresas que operavam no mercado no ano de 1999. Portanto, para analisar a estrutura deste mercado foram levantadas informações sobre as suas condições básicas bem como a parcela de mercado e os fatores estruturais que caracterizam e definem o poder das empresas da referida indústria.

Além dos dados primários também foram coletados dados e informações secundárias junto às seguintes fontes:

- Dados sobre a produção de pescado, número de produtores, área cultivada e destino da produção foram coletados nos relatórios da EMATER-Paraná sobre a Realidade da Piscicultura Regional e Estadual para as safras de 1996/1997, 1997/1998 e 1998/1999, uma vez que os dados da safra 1999/2000 não estavam disponíveis a partir na ocasião da pesquisa.

- Dados sobre a cadeia produtiva da piscicultura no Estado do Paraná foram obtidos junto à Secretaria de Estado da Agricultura e do Abastecimento (SEAB), à EMATER-Paraná, à Associação de Produtores de Alevinos do Paraná, em comunicação pessoal com representantes da empresas filiadas à Associação Brasileira de Produtores de Ração Animal. 
- Dados sobre o número de empresas com registro junto ao SIP/POA instaladas no Estado do Paraná e suas respectivas capacidades potenciais de produção, bem como a Legislação Sanitária que regulamenta a produção e a distribuição de pescado beneficiado e ou processado no Estado do Paraná foram obtidos junto à Secretaria de Estado da Agricultura e do Abastecimento;

- Os preços médios mensais recebidos pelos piscicultores por quilo vivo de tilápia-do-nilo e os preços médios mensais recebidos pela indústria na venda do filé de tilápia $(\mathrm{R} \$ / \mathrm{kg})$, no período de setembro/1995 a setembro/2000, foram coletados junto às duas maiores empresas instaladas na região Oeste do Estado.

- Os preços foram deflacionadas pelo Índice Geral de Preços - disponibilidade interna (IGP-DI), elaborado pela Fundação Getúlio Vargas, com base em junho de 2001.

\subsection{Métodos}

Com o objetivo de descrever a estrutura da indústria paranaense de beneficiamento de tilápias procedeu-se à análise do grau de concentração na referida indústria. Além das razões de concentração, para melhor analisar a estrutura da indústria, foram utilizadas informações dos questionários relacionadas às principais barreiras à entrada na indústria, às condições básicas de oferta e demanda e diferenciação do produto.

Para quantificar o grau de concentração da indústria de beneficiamento de tilápias do Paraná, utilizou-se o índice de Herfindahl-Hirschman (HHI), que é a soma do quadrado das parcelas de cada empresa na capacidade de produção do mercado e que pode ser representado matematicamente pela expressão (1)

$$
\mathrm{HHI}=\sum_{i=1}^{n}\left(\frac{x_{i}}{T}\right)^{2}
$$

em que n é o número total de produtores; $x_{i}$, a produção de filé de cada unidade de beneficiamento $i$, e $T$, a produção total do mercado. 
Neste trabalho procurou-se analisar o grau de concentração da referida indústria no mercado paranaense considerando-se as dezoito empresas instaladas e em funcionamento no Estado do Paraná (dez com autorização do SIP/POA e oito com registro junto ao SIM/POA) e uma empresa instalada no Estado de Santa Catarina e que comercializava filé de tilápia no Paraná em 1999. Além disso, por ser desconhecido o número de produtores artesanais, agregou-se toda a produção do Estado, considerandose uma empresa, de forma que, neste caso, $n$ é igual a vinte. Como medida do tamanho absoluto de cada firma $\left(\mathrm{x}_{\mathbf{i}}\right)$, no caso das empresas estaduais, utilizou-se a produção anual do ano de 1999, uma vez que esta foi totalmente comercializada no mercado estadual e, no caso da empresa catarinense, considerou-se o total comercializado no Paraná durante o mesmo período. Logo, $\mathrm{T}$ é igual ao total da produção das dezoito empresas estaduais somado à produção importada de Santa Catarina e à produção artesanal total vendida no Paraná no ano de 1999.

Conforme mostram Scherer \& Ross (1990), o HHI considera tanto o número de firmas quanto a desigualdade entre elas, variando entre $1 / \mathrm{n} \leq \mathrm{HHI} \leq 1$ (onde $\mathrm{n}$ é o número de firmas), tendo valor 1 para o monopólio e tendendo a zero quando o mercado tende à competição perfeita. Também declina com o aumento do número de firmas e aumenta com o aumento da desigualdade, dado o número de firmas.

Além do índice de HHI, foram também estudadas as parcelas de mercado das maiores empresas atacadistas de referida indústria, empregando-se para isso o índice de razão de concentração (market share) definido pela expressão (2)

$$
\mathrm{CRK}=\sum_{i=1}^{k} s_{i}
$$

em que $s_{i}$ é a parcela de mercado da i-ésima firma e $\mathrm{k}$, o número de firmas.

Apesar da simplicidade de cálculo, este índice torna-se um tanto arbitrário quando se procede à escolha do número $k$. Como a presente pesquisa refere-se a um estudo de mercado de um produto específico, a literatura indica usualmente valores entre três e oito (Bain, 1968). 
No cálculo dos índices de concentração da indústria estadual, também foram consideradas a produção das dezoito unidades de beneficiamento de pescado estaduais que operavam em 1999, somada à produção ofertada no Paraná pela empresa catarinense e à produção artesanal total elaborada por produtores e pesque-pagues em 1999. Neste caso, calculou-se o índice de concentração para $k=2, k=4$ e $k=8$ a fim de indicar a proporção de mercado dominada pelas duas, quatro e oito maiores empresas do mercado considerado.

Bain (1968) sugere uma classificação dos mercados, a partir dos valores encontrados para a razão de concentração, especialmente, para as quatro e as oito maiores firmas. O mercado é considerado altamente concentrado quando $65 \%<\mathrm{CR} 4$ $<75 \%$ e $85 \%<$ CR8 < 90\%; Existe concentração moderada quando 50\% < CR4 < 65\% e $70 \%<\mathrm{CR} 8<85 \%$; É considerado um mercado de baixa concentração aquele em que $35 \%<\mathrm{CR} 4<50 \%$ e $45 \%<\mathrm{CR} 8<70 \%$; e, por fim, pode-se admitir a ausência de concentração quando CR4 < 35\% e CR8 < 45\%.

Apesar de não se ter conhecimento da existência de outros trabalhos em que tenham sido realizadas estas análises para a cadeia produtiva do pescado, sabe-se que muitos estudos sobre agronegócios já foram realizados empregando esta metodologia. A exemplo, tem-se o estudo feito por Medeiros \& Reis (1999), que avalia o processo de concentração industrial e dos mecanismos de competição utilizados pelas empresas da cadeia alimentar da soja. Também tem-se o trabalho realizado por Oliveira \& Borges Júnior (1999) que analisa a estrutura de mercado da indústria receptora de leite no Brasil. Outro exemplo é o estudo feito por Leismann \& Aguiar (2001), que analisa o poder de mercado da indústria de esmagamento de soja no Brasil concluindo que o índice de concentração da indústria neste caso influencia os preços recebidos pelos produtores.

Em relação à conduta das empresas, foram analisados os dados dos questionários referentes à quantidade de informação que as firmas possuem em relação aos seus concorrentes, aos tipos de estratégias adotadas pelas firmas em relação aos mesmos, às formas de fixação de preço dos produtos produzidos, à implantação de 
programas de controle de qualidade, procurando relacionar aspectos da estrutura e da conduta desta indústria.

Quanto ao seu desempenho, a indústria de beneficiamento de tilápias foi avaliada através da análise da evolução dos preços do filé de tilápia, que é o principal produto comercializado pelas empresas, do comportamento das margens de comercialização do atacadista (neste caso, as proprias unidades de beneficiamento), da participação do produtor no preço de venda no atacado, do critério de fixação de preços adotada pelos atacadistas além da análise da evolução da produção e da produtividade na indústria, procurando sempre relacionar os resultados de desempenho com aspectos da estrutura e conduta da mencionada indústria.

Segundo Shang (1990), uma das formas mais utilizadas para avaliar o desempenho de um mercado é a margem de comercialização e a participação dos produtores nos preços ao consumidor. De acordo com Barros (1987) e Marques \& Aguiar (1993), a margem de comercialização pode ser entendida como a diferença no preço de um produto entre dois níveis de mercado hierarquizados, ajustado para as mesmas unidades do nível inferior, enquanto os custos de comercialização compreendem as despesas decorrentes das atividades de comercialização.

Ainda de acordo com Barros (1987) e Marques \& Aguiar (1993), os fatores que mais afetam as margens são:

a) Características do mercado: quanto mais competitivo for o mercado menores deverão ser as margens, enquanto um mercado oligopolizado tende a trabalhar com margens mais elevadas;

b) Características do produto: quanto mais processado e manuseado for o produto, maiores serão as margens;

c) Mudanças Tecnológicas: melhorias genéticas, do armazenamento e dos transportes tendem a reduzir os custos e margens de comercialização.

As margens podem ter significados diferentes dependendo da amplitude de mercado levada em consideração. Desta forma, geralmente, são calculadas a partir dos preços do produto em cada nível de mercado. 
A Margem Total Absoluta (MC) corresponde às despesas decorrentes das atividades de comercialização incorporadas aos preços pagos pelo consumidor e pode ser obtida a partir da equação (3)

$$
\mathrm{MC}=\mathrm{Pv}-\mathrm{Pp}
$$

onde:

$\mathrm{Pp}=$ é o preço real ao produtor

$\mathrm{Pv}=$ é o preço no varejo.

Partindo-se do conceito acima citado, verifica-se que é possível calcular margens de comercialização para níveis específicos de mercado, tais como:

a) A Margem Absoluta do Atacado (MA) que pode ser calculada a partir da equação (4),

$$
\mathrm{MA}=\mathrm{Pa}-\mathrm{Pp}
$$

onde:

$\mathrm{Pa}=$ é o preço real no atacado

b) A Margem Absoluta do Varejista ou a diferença entre o preço no varejo e o preço da quantidade equivalente no atacado pode ser obtida através da seguinte fórmula (5),

$$
\mathrm{MV}=\mathrm{Pv}-\mathrm{Pa}
$$

Já as margens relativas de comercialização também correspondem à diferença entre os preços praticados em dois níveis de mercado, só que expressas em termos de venda. As margens relativas podem ser obtidas a partir das fórmulas:

a) Margem Porcentual Total de Comercialização (MC'):

$$
\mathrm{MC}^{\prime}=(\mathrm{Pv}-\mathrm{Pp}) / \mathrm{Pv}
$$


b) Margem Porcentual do Atacado (MA')

$$
\mathrm{MA}^{\prime}=(\mathrm{Pa}-\mathrm{Pp}) / \mathrm{Pa}
$$

c) Margem Relativa do Varejista (MV')

$$
M^{\prime}=(P v-P a) / P v
$$

Segundo os mesmos autores, em comercialização também fala-se em mark-up, que é a margem absoluta expressa em termos de custo do produto. De modo geral é expresso como

$$
M V^{\prime \prime}=(\mathrm{Pv}-\mathrm{Pa}) / \mathrm{Pa}
$$

Dada a falta de dados de preços praticados pelo setor varejista na comercialização do filé de tilápia foram calculadas apenas as margens do setor atacadista medidas pelas equações (4) e (7).

No caso de produtos não sujeitos a transformações substanciais entre a fazenda e o consumidor final, como é o caso de frutas, verduras e legumes, existe maior facilidade de cálculo das margens setoriais. Já os produtos sujeitos a manipulação do seu estado natural e processamento são mais complexos de serem estudados. As carnes em geral, inclusive o pescado, enquadram-se neste caso, pois no mercado produtor consideram-se animais vivos, que vão sendo beneficiados e processados ao longo da cadeia produtiva até chegar ao consumidor final.

De acordo com Rissato \& Marques (1999), são necessários 3kg de peixe vivo para produzir $1 \mathrm{~kg}$ de filé. A partir dos $2 \mathrm{~kg}$ de sobras de pescado, a agroindústria paranaense tem obtido, em alguns casos, em média, 550g de farinha de peixe, $200 \mathrm{~g}$ de pele e $180 \mathrm{~g}$ de petisco. Os subprodutos obtidos no processo devem ser proporcionalmente descontados do peixe comprado do produtor, de acordo com a Figura 3. 
Para efeito de cálculo das Margens de Comercialização, os dados sobre a conversão física e o rendimento industrial médio foram obtidos a partir dos questionários aplicados aos proprietários das unidades de beneficiamento, constatandose que são necessários $3 \mathrm{~kg}$ de tilápia viva para produzir $1 \mathrm{~kg}$ de filé. No entanto, além de $1 \mathrm{~kg}$ de filé, podem também ser obtidas, em média, $120 \mathrm{~g}$ de pele e $90 \mathrm{~g}$ de petisco e a partir dos resíduos $(1,790 \mathrm{~kg})$, pode-se produzir, aproximadamente, $500 \mathrm{~g}$ de farinha de peixe.

Atualmente, somente uma das vinte empresas instaladas no Paraná aproveita os resíduos para elaboração destes sub-produtos, enquanto as demais empresas descartam os resíduos (pele e carcaça). Desta forma, optou-se por calcular as margens de comercialização do atacado (unidades de beneficiamento) para ambos os casos.

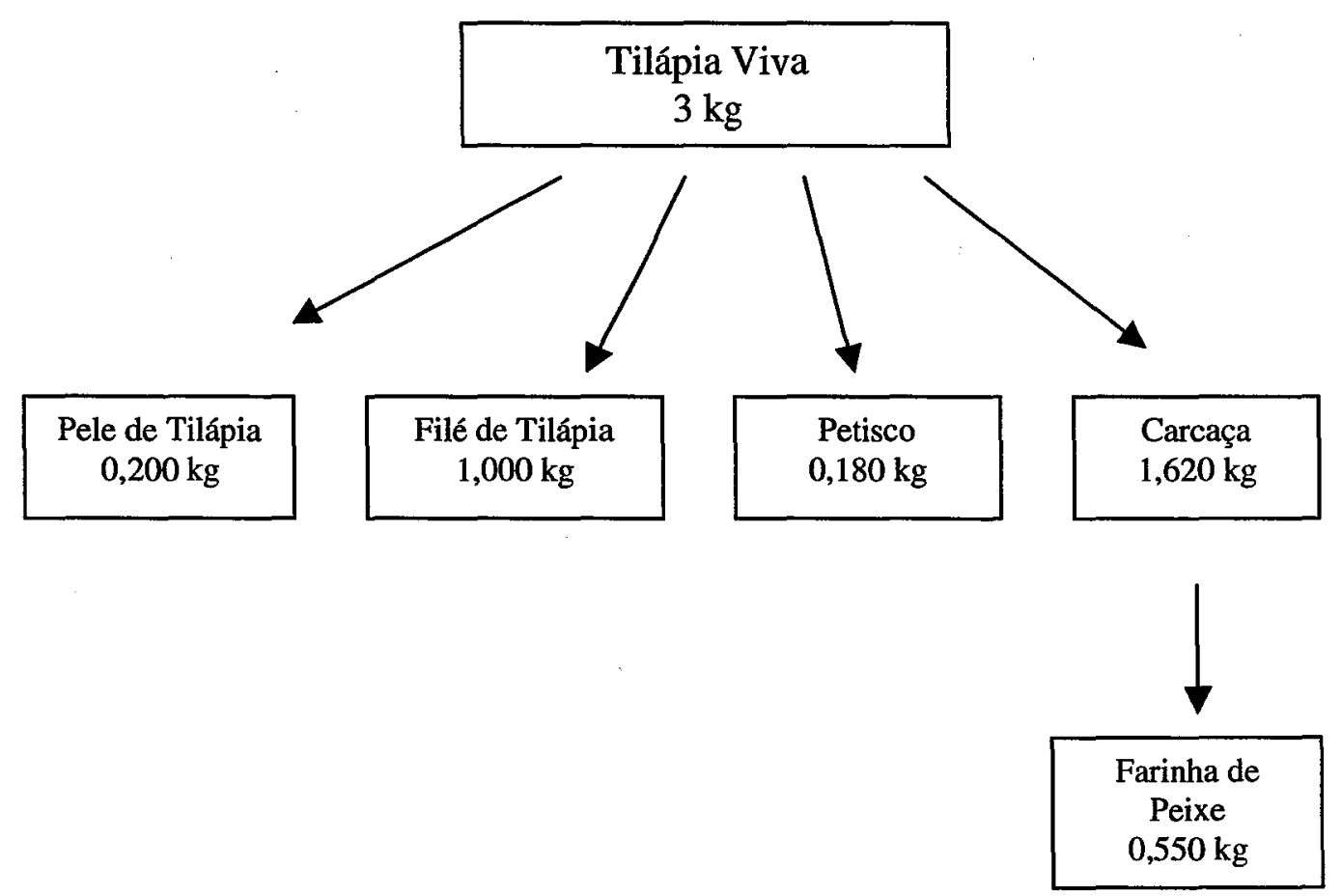

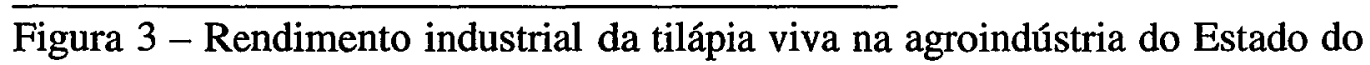
Paraná.

Fonte: Rissato \& Marques (1999) 
De acordo com Shang (1990), margens de comercialização representam os custos com serviços de comercialização tais como construção e instalação, processamento, transportes, estocagem, entre outros, mais algum lucro normal. Normalmente, quanto maior o número de serviços intermediários envolvidos na comercialização maiores serão as margens. Desta forma, uma queda nos preços ao produtor não implica necessariamente em redução dos preços pagos pelo consumidor.

Poucos trabalhos foram feitos no Brasil sobre a determinação de margens de comercialização do pescado. Neste caso, considera-se importante destacar o trabalho de Canto et al (1986) no qual foram apresentados coeficientes para determinação do preço equivalente-fazenda de diversos produtos, entre eles as carnes bovina, suína e de aves.

Dos poucos trabalhos feitos sobre as margens de comercialização de pescado no Brasil, podem ser citadas as contribuições de Carvalho et al (1980) que estudaram o comportamento das margens de comercialização de sardinha, camarão sete barbas e pescada média no Estado de São no período de 08/1975 a 02/1977, avaliando a relação das margens com as quantidades desembarcadas e comercializadas bem como a elasticidade de transmissão de preços entre os níveis atacadista e varejista. Os autores concluíram que a tendência das margens pode ser considerada constante para as espécies analisadas, dado que os coeficientes tendência não foram estatisticamente diferentes de zero, a nível de significância de 5\%. Concluíram também que a política adotada é de margem absoluta constante para a sardinha e para o camarão sete barbas e de margem absoluta decrescente para a pescada média. Constataram, no caso da sardinha, a existência de uma relação direta entre a margem de comercialização e as suas quantidades desembarcadas e comercializadas na CEAGESP enquanto, no caso do camarão sete barbas, verificaram uma relação direta para a quantidade desembarcada e inversa para a quantidade comercializada. No caso da pescada média concluíram que as quantidades desembarcadas e comercializadas não afetam as margens de comercialização. Com relação à elasticidade de transmissão de preços, concluíram que apenas parte da variação do preço do produto no atacado é transferida ao consumidor no caso do camarão sete barbas e muito pouco nos casos da sardinha e da pescada média. 
Pode-se citar Martin (1998) que calculou as margens de comercialização para as doze principais espécies capturadas no reservatório de Itaipu (dourado, pintado, armado grande, armado pequeno, sardela, curvina, traíra, tucunaré, jaú, curvinão, pernade-moça e bagre pequeno). A autora obteve os seguintes resultados:

a) Margens pescadores-colônia variam entre 12,5 e $38 \%$, principalmente para as espécies inferiores $\left(3^{*} \text { classe }\right)^{9}$.

b) No nível peixeiro-supermercado, a margem relativa varia entre 8 e $33 \%$ sendo maiores as margens das espécies mais capturadas quando sofrem aumentos consideráveis com variações de $49 \%$.

c) As margens totais absolutas (pescadores-supermercados) variam entre 100 e $243 \%$, considerando margens maiores para as espécies de $3^{\mathrm{a}}$ classe. As margens totais relativas sofrem variações entre 8 e $243 \%$. Esse estudo evidenciou que as maiores margens ocorrem em torno dos pescados mais comercializados em decorrência dos menores preços pagos aos pescadores e das quantidades comercializadas.

Cabe salientar que apesar de se tratarem de espécies provenientes da pesca extrativa acredita-se que, pelas características do produto, os resultados possam ser comparados aos que serão obtidos neste trabalho. Outro fator que torna esses resultados interessantes é que o pescado extraído do reservatório de Itaipu é comercializado em alguns importantes mercados (Cascavel, Toledo e Curitiba) do filé de tilápia, espécie estudada neste trabalho.

Pode-se citar também o trabalho realizado por Rissato \& Marques (1999), onde são calculadas as margens de comercialização da tilápia-do-nilo criada em cativeiro no Extremo Oeste paranaense.

Foram calculadas margens, considerando o caso da agroindústria que aproveita e ou comercializa as sobras como pele, carcaça e "barriguinha" da tilápia beneficiada e o caso da agroindústria que descarta todos estes resíduos, concluindo que existem diferenças entre os dois possíveis casos. A agroindústria que aproveita os sub-produtos

\footnotetext{
${ }^{9}$ São consideradas espécies de pescado de terceira classe ou inferiores aquelas de médio porte, tais como, barbado, cascudo e armado. Essas espécies geralmente caracterizam-se pela carne de bom paladar. No entanto, devido à aparência o consumidor tem restrições.
} 
obtém margens maiores sobre o filé vendido do que a agroindústria que descarta todos os sub-produtos da tilápia, conforme Tabela 13.

Tabela 13. Margens de comercialização do atacadista para o filé de tilápia no Estado do Paraná

\begin{tabular}{lc}
\hline Estrutura da Cadeia & $\begin{array}{c}\text { Margem Relativa } \\
(\%)\end{array}$ \\
\hline & Com o aproveitamento dos sub-produtos \\
Produtor & - \\
Agroindústria & 54,47 \\
Varejo & 31,88 \\
& Sem o aproveitamento dos sub-produtos \\
Produtor & - \\
Agroindústria & 42,31 \\
Varejo & 27,78 \\
\hline
\end{tabular}

Fonte: Rissato \& Marques (1999).

Como pode-se observar, muito pouco ainda foi estudado sobre margens de comercialização de pescado no Brasil. Além disso, é importante destacar que os trabalhos realizados por Martin (1998) e Rissato \& Marques (1999) utilizaram preços de um dado momento no tempo, não permitindo que se observe as suas variações e a sua evolução ao longo de um período. Sem dúvidas, esta é uma limitação desses estudos, pois é extremamente importante avaliar o comportamento das margens ao longo do tempo.

A participação do produtor no preço pago pelo consumidor é outro indicador de desempenho de mercado. De acordo com Shang (1990), a alta participação dos produtores nos preços pagos pelo consumidor e as baixas margens de comercialização geralmente indicam que o mercado específico é eficiente. No entanto, de acordo com Marques \& Aguiar (1993), em geral, a participação dos produtores tende a ser maior no caso de produtos pouco manuseados ou processados.

Shang (1990) ressalta, ainda, que as margens e os custos de comercialização para os produtos da aqüicultura são freqüentemente altas, especialmente nos países 
desenvolvidos, como resultado dos investimentos em tecnologia para melhorar a qualidade, divulgação e distribuição dos produtos. 


\section{RESULTADOS E DISCUSSÃo}

Neste capítulo analisa-se organização da indústria de filetagem de tilápias criadas em cativeiro no Estado do Paraná, utilizando-se para isso o paradigma estruturaconduta-desempenho.

\subsection{A organização da indústria de beneficiamento de tilápias-do nilo no Estado do} Paraná

Para caracterizar a estrutura deste mercado foi necessário diagnosticar a produção total ofertada no mercado paranaense, tanto por empresas oficialmente instaladas e por produtores e ou por pesque-pagues que produzem artesanalmente o filé de tilápia em diversas regiões do Estado quanto por empresas estabelecidas em outros estados. Para que a produção artesanal, industrial e proveniente de outros estados pudessem ser comparadas e confrontadas com a demanda estadual e para que pudessem ser calculadas as respectivas parcelas de mercado de cada empresa, foram consideradas apenas as dezoito empresas que operavam no mercado no ano de 1999 , uma vez que as estatísticas da produção estadual de pescado na safra 1999/2000 ainda não estavam disponíveis para que pudesse ser estimada a produção artesanal.

Inicialmente serão analisadas as características das condições básicas da oferta e da demanda (sub-itens 5.1.1 e 5.1.2) e as políticas governamentais (sub-item 5.1.3) enquanto fatores determinantes da estrutura de mercado. A seguir, verifica-se a existência ou não de barreiras à entrada de novas firmas na indústria de beneficiamento 
de pescado, o grau de diferenciação do produto, bem como o grau de concentração da referida indústria (5.1.4).

\subsubsection{Condições básicas da oferta}

Alguns aspectos referentes às condições básicas de oferta e demanda foram analisadas levando-se em consideração todas as vinte empresas entrevistadas, inclusive aquelas que começaram a operar no mercado somente no ano 2000.

Com relação às condições básicas de oferta desta indústria foram analisados seis aspectos, verificando-se que:

1) a indústria de beneficiamento de tilápias-do-nilo do Paraná, em 1999, era formada por dezoito empresas oficialmente estabelecidas, entre as quais dez possuíam licença do Serviço de Inspeção Sanitária do Estado do Paraná (SIP) e oito delas possuíam licença do Serviço de Inspeção Sanitária Municipal (SIM). Além da produção industrial, havia uma produção artesanal realizada regularmente, ao longo do ano, por piscicultores e por pesque-pagues de diversos municípios, conforme Tabela 14.

Analisando a Figura 4, verifica-se que, em 1999, a produção industrial propriamente dita correspondeu a $72,52 \%$ do total produzido no Estado, enquanto a produção artesanal respondeu por $27,48 \%$. Essa alta participação da produção artesanal pode ser explicada pela significativa contribuição dos pesque-pagues, que venderam em forma de filé cerca de $15 \%$ da tilápia comercializada em seus estabelecimentos.

Apesar da existência de leis que visam aumentar a confiabilidade do produto e também reduzir a informalidade, alguns fatores explicam a existência e a manutenção dos abates clandestinos. Entre eles, podem ser destacados: (a) o costume popular de comprar peixe "fresco" daqueles produtores que vendem "de porta em porta" ou em feiras, independentemente de que sejam fiscalizados, (b) a carga tributária elevada e burocracia, (c) a fiscalização que concentra seus esforços nos estabelecimentos legalizados reduzindo os riscos para a clandestinidade e possibilitando uma concorrência desleal com as empresas que operam no mercado formal, bem como (d) a sensibilidade do consumo em relação ao preço do pescado e a existência de produtos concorrentes. 
Tabela 14. Produção de filé de tilápia no Estado do Paraná em 1999.

\begin{tabular}{|c|c|c|c|c|}
\hline \multirow[t]{2}{*}{ Região } & \multirow{2}{*}{$\begin{array}{c}\text { Produção } \\
\text { Industrial } \\
\text { (ton/ano) }\end{array}$} & \multicolumn{2}{|c|}{$\begin{array}{l}\text { Produção Artesanal } \\
\text { (ton/ano) }\end{array}$} & \multirow{2}{*}{$\begin{array}{l}\text { Produção Total por } \\
\text { Macrorregião } \\
\text { (ton/ano) }\end{array}$} \\
\hline & & Piscicultores & Pesque-pagues & \\
\hline Paranaguá & - & 1,5 & 1,19 & 2,69 \\
\hline Curitiba & - & - & 3,53 & 3,53 \\
\hline União da Vitória & - & - & 1,74 & 1,74 \\
\hline Ponta Grossa & - & 4,07 & 1,34 & 5,41 \\
\hline Guarapuava & - & 0,5 & 1,80 & 2,30 \\
\hline Irati & - & 0,35 & 2,01 & 2,36 \\
\hline Lapa & - & 0,46 & 0,23 & 0,69 \\
\hline Umuarama & $\begin{array}{c}19,2 \\
01\end{array}$ & 5,61 & 6,26 & 31,07 \\
\hline Campo Mourão & - & 4,59 & 5,90 & 10,49 \\
\hline Apucarana & - & 1,06 & 3,54 & 4,60 \\
\hline Paranavaí & - & 0,28 & 1,84 & 2,12 \\
\hline Maringá & $\begin{array}{l}7,2 \\
01\end{array}$ & 24,25 & 8,15 & 39,60 \\
\hline Ivaiporã & $\begin{array}{c}12,0 \\
01\end{array}$ & 7,20 & 2,97 & 22,17 \\
\hline Londrina & - & 0,58 & 4,02 & 4,60 \\
\hline Cornélio Procópio & - & 6,15 & 18,08 & 24,23 \\
\hline Santo Ant $^{\circ}$. da Platina & - & 2,78 & 3,89 & 6,67 \\
\hline Pato Branco & $\begin{array}{c}66,0 \\
06\end{array}$ & 6,40 & 6,43 & 78,83 \\
\hline Francisco Beltrão & $\begin{array}{c}65,0 \\
04\end{array}$ & 2,60 & 6,06 & 73,66 \\
\hline Cascavel & $\begin{array}{c}35,64 \\
01\end{array}$ & 28,8 & 31,45 & 95,89 \\
\hline Toledo & $\begin{array}{c}476,83 \\
04\end{array}$ & 20,63 & 30,17 & 527,63 \\
\hline Total no Estado & $\begin{array}{r}681,87 \\
72,52 \% \\
\end{array}$ & $\begin{array}{c}117,81 \\
12,53 \%\end{array}$ & $\begin{array}{r}140,60 \\
14,95 \%\end{array}$ & $\begin{array}{l}940,28 \\
100,0 \% \\
\end{array}$ \\
\hline
\end{tabular}

Fonte: Dados da pesquisa. 


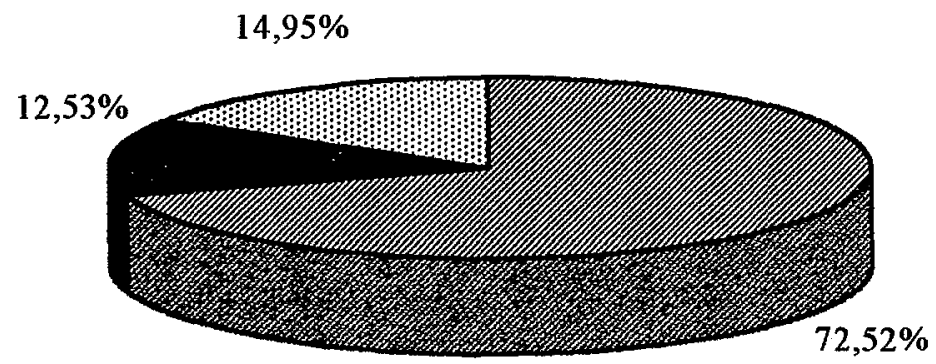

Q Produção Industrial

- Produção nas Propriedades

EProdução dos Pesque-pague

Figura 4 - Participação relativa da indústria e dos produtores artesanais na produção total de filé de tilápia no Estado do Paraná, em 1999.

Desde a instalação da primeira unidade de beneficiamento de tilápias no Oeste do Paraná, a produção industrial de filé de tilápia tem crescido continuamente, com exceção do ano de 1996, devido a saída da uma importante empresa do mercado, conforme Tabela 15.

Ainda, de acordo com a Tabela 15, observam-se significativas diferenças na escala de produção das empresas. Essas diferenças se explicam por vários fatores, tais como o período em que a empresa está no mercado, matéria-prima empregada (própria ou comprada), mercados onde comercializa a produção (municipal ou estadual), etc. A fim de preservar a identidade das empresas entrevistadas optou-se por não adicionar ao texto informações que permitam aos leitores identificá-las.

A empresa um foi a primeira empresa a se estabelecer no Paraná, em 1995, a partir de quando dominou o mercado estadual até 1997.

A empresa dois ingressou no mercado com SIP em maio de 1997. No entanto, inicialmente obteve uma produção muito baixa devido a falta de matéria-prima, passando a operar com SIF a partir de julho/2000. 
Tabela 15. Evolução da quantidade de filé vendida pela indústria de beneficiamento de tilápiado-nilo instalada na região Oeste paranaense no período de 1995 a 1999.

\begin{tabular}{lcccccc}
\hline Empresas & 1995 & 1996 & 1997 & 1998 & 1999 & 2000 \\
\hline Empresa 1 & 129,31 & 135,35 & 200,59 & 209,6 & 216,0 & 258,7 \\
Empresa 2 & - & - & 17,0 & 180,54 & 248,83 & 231,8 \\
Empresa 3 & - & - & - & - & 9,6 & 9,6 \\
Empresa 4 & 2,4 & 2,4 & 2,4 & 2,4 & 2,4 & 2,4 \\
Empresa 5 & 44,0 & - & - & - & - & - \\
Empresa 6 & - & - & - & - & 35,64 & $53,4 *$ \\
Empresa 7 & - & - & - & - & - & 6,6 \\
Empresa 8 & & & & & & 20,0 \\
Total Produzido & 175,71 & 137,75 & 219,99 & 392,54 & 512,47 & 582,5 \\
Variação \% & - & $-21,60$ & 59,70 & 78,44 & 30,55 & 13,67 \\
\hline
\end{tabular}

Fonte: Dados da pesquisa.

* Valor estimado

A empresa três, propriedade de um pequeno empresário rural, começou a operar com SIP em janeiro de 1999 empregando apenas matéria-prima própria, o que explica a sua baixa escala de produção. É importante destacar que, segundo o proprietário, a empresa foi instalada, a princípio, para beneficiar apenas a tilápia cultivada na propriedade.

A empresa quatro é a única unidade com Inspeção Sanitária Municipal (SIM) instalada na região Oeste do Estado e, segundo o seu proprietário, nos últimos anos, a produção tem se mantido constante, uma vez que utiliza apenas matéria-prima própria e trabalha para atender às encomendas e as necessidades de subsistência da família.

A empresa cinco permaneceu no mercado apenas no ano de 1995 devido a problemas gerenciais e à escassez de matéria-prima. Quanto à empresa seis, constatou-se que iniciou suas atividades no mês de maio de 1999, empregando matéria-prima comprada e vendendo no mercado estadual. As empresas sete e oito ingressaram no mercado com SIF, nos meses $11 / 2000$ e 06/2000, respectivamente. 
2) a técnica utilizada no processo de beneficiamento (filetagem) do pescado é disponível no mercado e é similar em todas as firmas da indústria. Segundo ContrerasGuzmán citado por Maranhão (1998), o aproveitamento e o rendimento do filé depende da eficiência das máquinas filetadoras, da destreza dos operários e da forma anatômica do corpo do peixe.

De acordo com Maranhão (1998), é importante destacar que o filé de tilápia extraído manualmente apresenta um rendimento superior em relação ao peso vivo, em até 4\%, se comparada com a extração automática. Além disso, a utilização das sobras de tilápia-do-nilo para elaboração de produtos alimentícios ainda é pouco comum no Brasil.

No Paraná, todas as unidades de beneficiamento de tilápias elaboram o filé manualmente com uma tendência para a especialização de tarefas, uma vez que a destreza, a habilidade e a prática dos trabalhadores da produção são fundamentais para o bom desempenho do setor.

Conclui-se que, no caso da indústria paranaense de beneficiamento de tilápias, o método de extração de filé utilizado é o mais interessante pois proporciona maior rendimento e o menor desperdício de carne uma vez que a carcaça é descartada. Com relação ao aproveitamento das sobras de tilápia, observa-se que apenas uma empresa produz farinha de peixe com as vísceras, a cabeça e os ossos do peixe filetado. No entanto, as sobras de peixe poderiam ser melhor aproveitadas se fossem utilizadas máquinas separadoras de carne e osso ou despolpadoras.

3) a espécie tilápia-do-nilo (Oreochromis niloticus) é a matéria-prima básica da referida indústria. Cabe destacar que $20 \%$ das empresas adquirem via mercado toda a matéria-prima utilizada, $35 \%$ delas obtêm, em média, $51 \%$ da matéria-prima necessária no mercado, enquanto $35 \%$ utilizam somente matéria-prima própria e $10 \%$ delas não responderam a questão.

Observa-se que os proprietários das unidades de beneficiamento de tilápia, em alguns casos, são produtores de alevinos e ou donos de pesque-pagues e, em geral, são piscicultores e comercializam toda sua produção junto a sua própria empresa. Isso explica por que algumas empresas utilizam somente matéria-prima própria. Em alguns casos, com o objetivo de agregar valor ao seu produto, esses pequenos piscicultores 
acabaram construindo as unidades de beneficiamento apenas para filetar o pescado cultivado em sua propriedade e, apesar da grande capacidade ociosa existente na empresa, não desejam ampliar a produção comprando matéria-prima de terceiros.

Ainda, quando questionadas sobre o interesse e a necessidade de trabalhar em regime de cooperação com os produtores, $45 \%$ das empresas responderam que seria interessante a indústria estabelecer contratos com os piscicultores, $40 \%$ responderam que o mercado é a melhor opção e $15 \%$ não responderam a questão. Cabe destacar que sete das nove empresas que consideram interessante estabelecer contratos com os produtores são empresas que comercializam sua produção no mercado estadual, pois possuem SIP ou SIF, ou seja, são as empresas que apresentam maior escala de produção e também estão mais preocupadas com a qualidade da matéria-prima utilizada.

4) apesar do aumento da oferta de tilápia viva durante a primavera e o verão, a concorrência dos pesque-pagues obriga a indústria a manter e, às vezes, até elevar os preços pagos aos produtores a fim de garantir a matéria-prima. Esse fato é um forte indicativo de que há escassez de peixe durante a primavera e o verão, em função do aumento sazonal da demanda de peixe vivo.

Com relação à disponibilidade de matéria-prima, nove empresas (45\%) afirmaram existir escassez de matéria-prima, enquanto nove delas consideram abundante a oferta de tilápia viva e duas não responderam. Neste caso, é importante destacar que $78 \%$ das empresas que afirmaram existir escassez de matéria-prima produzem filé em grande escala e compram no mercado, em média, $94 \%$ do peixe vivo que necessitam ao longo do ano enquanto, $78 \%$ das empresas que sustentam ser abundante a oferta de matéria-prima (tilápia) são empresas que produzem em pequena escala e comercializam apenas no mercado local em seus respectivos municípios. Além disso, as nove empresas que consideram abundante a oferta de tilápia viva compram no mercado, em média, apenas $12 \%$ de matéria-prima que necessitam. Considerando-se que as empresas que enfrentam a escassez de matéria-prima são as responsáveis por grande parte da produção estadual de filé conclui-se que existe escassez de matéria-prima para a indústria de beneficiamento de tilápia. 
5) não existe uma associação de classe das empresas que fazem o beneficiamento de tilápia no Paraná.

6) o produto elaborado pelas empresas estudadas, o filé de tilápia, é um produto relativamente perecível, dependendo da forma de acondicionamento. Se for mantido resfriado pode ser consumido em até 8 (oito) dias e se for congelado $\left(-12^{\circ} \mathrm{C} \mathrm{a}-15^{\circ} \mathrm{C}\right.$ ) tem validade para consumo de 6 a 8 meses.

\subsubsection{Condições básicas da demanda}

Ao analisar as condições básicas de demanda desta indústria, destacou-se sete aspectos mais relevantes, verificando-se que:

1) o produto principal elaborado pela indústria de beneficiamento, o filé de tilápia, pode ser facilmente substituído tanto pelo frango quanto por outras espécies de pescado. Além disso, pesquisas de mercado realizadas em algumas cidades do Paraná relatam que o consumidor considera o preço do filé de tilápia muito elevado. Segundo Libardi et al (1996), de acordo uma consultora nutricional que presta serviços a várias indústrias de refeições prontas em Curitiba, é servido peixe (filé de merluza importado da Argentina) nas refeições industriais, em porções de 150 gramas, entre uma e duas vezes por mês. A nutricionista também destacou que apesar da tentativa e do interesse em substituir o filé de merluza pelo filé de tilápia, tal fato não ocorreu por dois motivos: o filé é muito pequeno e o preço muito elevado. Rissato et al (1996), em uma pesquisa de mercado realizada na cidade de Palotina/PR, $60 \%$ dos entrevistados afirmaram não consumir filé de tilápia pelo seu preço muito elevado.

Ainda, de acordo com Martin (1998), consumidores entrevistados em Toledo e Cascavel afirmaram que não consomem peixe em maiores quantidades ou com maior freqüência porque seu preço é muito elevado. Além do preço, acredita-se a que demanda de pescado também depende do nível de renda do consumidor. Martin (1998) constatou em sua pesquisa que $42,5 \%$ dos consumidores de pescado da cidade de Cascavel e que 
35\% dos consumidores de pescado de Toledo ganham mais de seis salários mínimos, enquanto apenas $5 \%$ e $2,5 \%$, respectivamente, ganham até um salário mínimo.

Acredita-se, portanto, que o preço do filé de tilápia e a renda do consumidor são fatores decisivos para que seja consumido. De acordo com estudos já realizados por Morimoto (1975), Okawa (1985) e Hoffmann (2000), observa-se que, em geral, a demanda de pescado fresco e processado é elástica em relação ao preço. Morimoto (1975) ao analisar a "Demanda de pescado no mercado da grande São Paulo" concluiu que a elasticidade-preço da demanda era igual a -1,36. Okawa (1985), que avaliou a elasticidade-preço da demanda para sardinha fresca no mercado atacadista de São Paulo, concluiu que um aumento de $10 \%$ no preço seria acompanhado por uma redução, a curto prazo, de $18,2 \%$ e, a curtíssimo prazo, de $21,2 \%$ na quantidade procurada, mantendo-se constantes todas as demais variáveis.

Tabela 16. Elasticidade-renda da despesa com carnes e pescado no período de 1995 a 1996.

\begin{tabular}{lc}
\hline Tipo de despesas & Elasticidade média \\
\hline Carne de boi de primeira & 0,482 \\
Carne de boi de Segunda & 0,048 \\
Carne de suíno & 0,443 \\
Carnes e peixes industrializados & 0,405 \\
Frango & 0,155 \\
Pescados frescos & 0,367 \\
\hline
\end{tabular}

Fonte: Extraída de Hoffmann (1996)

Hoffmann (2000), que calculou a elasticidade-renda das despesas com alimentos em regiões metropolitanas do Brasil, em 1995-96, concluiu que a demanda de pescado é bastante sensível às variações na renda familiar. De acordo com a tabela 16, observa-se que as carnes e pescados industrializados e ou frescos são bens superiores, pois quando aumenta a renda, aumenta o consumo destes produtos. Observa-se que os 
coeficientes de elasticidade-renda da demanda para o pescado são maiores do que para o frango indicando que a demanda do pescado é muito mais sensível às variações na renda, podendo ser facilmente substituído pelo frango, principalmente, nas faixas mais baixas de renda.

2) o consumo de filé de tilápia no Paraná, em 1999, foi de 973,88 toneladas. Considerando-se que todo o filé de tilápia produzido no Paraná, no período foi comercializado no mercado estadual, pois nenhuma empresa possuía licença sanitária para exportar sua produção para outras regiões, sabe-se que $96,55 \%$ da demanda estadual de filé foi suprida por produção própria e 3,45\% desta foi atendida através da importação de filé produzido no estado de Santa Catarina, conforme Tabela 17.

Tabela 17. Consumo de filé de tilápia no Estado do Paraná em 1999.

\begin{tabular}{|c|c|c|c|c|c|}
\hline & \multirow{2}{*}{$\begin{array}{c}\text { Produção } \\
\text { Industrial } \\
\text { t/ano }\end{array}$} & \multicolumn{2}{|c|}{ Produção Artesanal (t/ano) } & \multirow{2}{*}{$\begin{array}{c}\text { Produção de } \\
\text { Outros Estados } \\
\text { (t/ano) }\end{array}$} & \multirow{2}{*}{$\begin{array}{c}\text { Demanda } \\
\text { Total } \\
\text { (t/ano) }\end{array}$} \\
\hline & & Piscicultores & Pesque-pagues & & \\
\hline \multicolumn{6}{|l|}{ Consumo de Filé de } \\
\hline Tilápia & 681,87 & 117,81 & 140,60 & 33,60 & 973,88 \\
\hline Participação Relativa & $70,02 \%$ & \multicolumn{2}{|c|}{$26,53 \%$} & $3,45 \%$ & $100 \%$ \\
\hline
\end{tabular}

Fonte: Dados da pesquisa.

3) de acordo com esta pesquisa, constata-se que, durante a primavera e o verão, ocorre um aumento sazonal da quantidade consumida de filé de tilápia, atingindo seu ponto máximo durante os quarenta dias que antecedem a festa da Páscoa sofrendo, em seguida, uma significativa redução, ficando caracterizada a existência de escassez de matéria-prima durante a primavera e o verão, em função do aumento sazonal da demanda de peixe vivo.

4) observa-se, de acordo com a pesquisa, que existem compradores de filé de tilápia em todo o Estado do Paraná, principalmente, nas regiões Oeste, Norte, Sudoeste e região metropolitana de Curitiba. Considerando que não foi possível determinar a 
produção e consumo total de filé de tilápia no Paraná, no ano 2000 , pois ainda não estavam disponíveis os dados sobre a produção informal, procurou-se especificar o fluxo de filé de tilápia, por regiões, no Paraná, em 1999, conforme mostrado na Tabela 18.

Conforme já mencionado anteriormente, as empresas estabelecidas no Estado em 1999, não possuíam licença do Serviço de Inspeção Sanitária Federal (SIF), não estando aptas a comercializar sua produção fora do Estado. Logo, 96,9\% da produção estadual foi comercializada no Paraná e 3,1\% da produção total foi vendida clandestinamente, em pequenas quantidades, para viajantes, pesque-pagues e restaurantes de outros Estados (Tabela 18).

Verifica-se que, em 1999, a região Oeste foi o principal mercado de filé, consumindo 349,89 toneladas de produto, o equivalente a $37,21 \%$ da produção total do Estado, sendo que $94,15 \%$ da quantidade consumida foi produzida na própria região e $5,85 \%$ foi produzida na região Sudoeste. Isto se deve ao fato da região Oeste ter sido pioneira na piscicultura estadual destinando, inicialmente, toda a produção ao mercado regional, difundindo o seu produto e suas marcas na região (Tabela 18).

A região Sul consumiu 227,11 toneladas de filé de tilápia em 1999. Este mercado regional absorveu produção procedente de várias regiões do Paraná, entre elas, da própria região Sul $(8,24 \%)$, da região Norte $(1,59 \%)$, da região Sudoeste $(12,09 \%)$ e da região Oeste $(63,29 \%)$. Além disso, cerca de $14,79 \%$ do consumo de filé de tilápia da região Sul, em 1999, foi suprido com produto produzido em Santa Catarina. Cabe destacar que esta foi a única região que consumiu filé proveniente de outros estados e que foi o segundo maior mercado consumidor do filé produzido na região Oeste (ver Tabela 18).

O terceiro maior mercado consumidor de filé de tilápia do Paraná foi a região Norte do Estado que, apesar de possuir apenas uma unidade de beneficiamento de tilápias, é a segunda região que mais consumiu filé em 1999, aproximadamente 195,47 toneladas, o equivalente a $20,79 \%$ da produção estadual. Cabe destacar que $50,13 \%$ do filé consumido nesta região foi de procedência regional e $49,87 \%$ deste foi produzido na região Oeste, de acordo com a Tabela 18. 
Tabela 18. Fluxo de filé de tilápia no Estado do Paraná em 1999.

\begin{tabular}{|c|c|c|c|c|c|c|c|}
\hline Pólos regionais & $\begin{array}{c}\text { Região } \\
\text { Norte }\end{array}$ & $\begin{array}{c}\text { Região } \\
\text { Sul }\end{array}$ & $\begin{array}{c}\text { Região } \\
\text { Noroeste }\end{array}$ & $\begin{array}{c}\text { Região } \\
\text { Sudoeste }\end{array}$ & $\begin{array}{l}\text { Região } \\
\text { Oeste }\end{array}$ & $\begin{array}{l}\text { Outras } \\
\text { Regiões }\end{array}$ & $\begin{array}{l}\text { Produção de } \\
\text { filé por regiōes } \\
\text { (ton) }\end{array}$ \\
\hline \multicolumn{8}{|l|}{ Sul } \\
\hline Paranaguá & - & 2,69 & - & - & - & - & 2,69 \\
\hline Curitiba & - & 3,53 & - & - & - & - & 3,53 \\
\hline União da Vitória & - & 1,74 & - & - & - & - & 1,74 \\
\hline Ponta Grossa & - & 5,41 & - & - & - & - & 5,41 \\
\hline Guarapuava & - & 2,30 & - & - & - & - & 2,30 \\
\hline Irati & - & 2,36 & - & - & - & - & 2,36 \\
\hline Lapa & - & 0,69 & - & - & - & - & 0,69 \\
\hline \multicolumn{8}{|l|}{ Noroeste } \\
\hline Umuarama & - & - & 31,07 & - & - & - & 31,07 \\
\hline Campo Mourão & - & - & 10,49 & - & - & - & 10,49 \\
\hline \multicolumn{8}{|l|}{ Norte } \\
\hline Apucarana & 4,60 & - & - & - & - & - & 4,60 \\
\hline Paranavaí & 2,12 & - & - & - & - & - & 2,12 \\
\hline Maringá & 39,60 & - & - & - & - & - & 39,60 \\
\hline Ivaiporã & 16,17 & 3,6 & 1,2 & - & - & 1,2 & 22,17 \\
\hline Londrina & 4,60 & - & - & - & - & - & 4,60 \\
\hline Cornélio Procópio & 24,23 & - & - & - & - & - & 24,23 \\
\hline Sto. A. da Platina & 6,67 & - & - & - & - & - & 6,67 \\
\hline \multicolumn{8}{|l|}{ Sudoeste } \\
\hline Pato Branco & - & 10,18 & - & 56,83 & 11,82 & - & 78,83 \\
\hline Francisco Beltrão & - & 17,28 & - & 44,3 & 8,64 & 3,44 & 73,66 \\
\hline \multicolumn{8}{|l|}{ Oeste } \\
\hline Cascavel & 3,56 & 1,80 & 1,80 & 1,80 & 85,13 & 1,8 & 95,89 \\
\hline Toledo & 93,92 & 141,93 & 23,74 & - & 244,30 & 23,74 & 527,63 \\
\hline $\begin{array}{l}\text { Produção Total } \\
\text { de Filé }\end{array}$ & 195,47 & 193,51 & 68,30 & 102,93 & 349,89 & 30,18 & 940,28 \\
\hline Outros Estados & - & 33,6 & - & - & - & - & 33,6 \\
\hline $\begin{array}{l}\text { Total de filé } \\
\text { consumido em } \\
\text { cada região do } \\
\text { Estado (ton) }\end{array}$ & 195,47 & 227,11 & 68,30 & 102,93 & 349,89 & 30,18 & 973,88 \\
\hline
\end{tabular}

Fonte: Dados da Pesquisa 
A região Sudoeste, a segunda maior produtora de filé de tilápia do Estado, caracterizou-se, em 1999, como o quarto mercado consumidor estadual, consumindo 102,93 toneladas de filé, cerca de $10,95 \%$ da produção total do Estado, sendo que $98,25 \%$ desta produção foi realizada na própria região e $1,75 \%$ foi produzida em Cascavel, na região Oeste, (Tabela 18).

A região Noroeste do Paraná representou o menor consumo de filé de tilápia em todo o Estado, em 1999, em torno de 68,30 toneladas $(7,01 \%$ da produção total do Estado). Isto se deve, segundo as empresas entrevistadas e que comercializam na região, à baixa produção regional e também ao baixo poder aquisitivo da maioria da população. Todo o filé de tilápia produzido no Noroeste do estado foi comercializado na própria região atendendo cerca de $60,85 \%$ do mercado consumidor. Aproximadamente $37,39 \%$ do consumo regional foi atendida com filé proveniente da região Oeste e $1,76 \%$ do filé consumido neste mercado foi produzido na região Norte (ver Tabela 18).

5) ainda, com relação aos compradores e distribuidores do filé de tilápia, observa-se que, enquanto as empresas com SIP possuíam, em média, trinta e seis clientes ou distribuidores do seu produto, as empresas com SIF possuíam, no ano 2000, em média, 85 compradores atacadistas e ou varejistas, embora tenham comercializado toda a sua produção no mercado estadual. Já as empresas com SIM contavam, em média, com 28 compradores de filé de tilápia, um número não tão pequeno se comparado com as empresas com SIP que, geralmente, produzem quantidades muito maiores de filé do que as empresas que possuem licença sanitária municipal. É importante destacar, no entanto, que as empresas com SIP, especialmente as maiores, comercializam grande parte de sua produção junto a redes de supermercados e ou terceirizam os serviços de vendas, enquanto as empresas com SIF têm sua própria equipe de vendas e as empresas com SIM caracterizam-se por vender apenas no mercado local, pequenas quantidades de produto e para maior número de firmas e ou consumidores finais, conforme Tabela 19. 
Tabela 19. Número médio de compradores de filé de tilápia, por empresa, no ano de 2000.

\begin{tabular}{lccc}
\hline & $\begin{array}{c}\text { Empresas com } \\
\text { SIF }\end{array}$ & $\begin{array}{c}\text { Empresas com } \\
\text { SIP }\end{array}$ & $\begin{array}{c}\text { Empresas com } \\
\text { SIM }\end{array}$ \\
\hline Número de firmas & 3 & 9 & 8 \\
Número Médio de Compradores & 85 & 36 & 28 \\
\hline
\end{tabular}

Fonte: Dados da pesquisa.

6) no que diz respeito aos canais de distribuição da produção utilizados pelas vinte empresas entrevistadas, para distribuir o filé de tilápia, observa-se que todas elas comercializam parte de sua produção diretamente com o consumidor final, $85 \%$ delas vendem aos supermercados e $75 \%$ das unidades de beneficiamento vendem filé em restaurantes, lanchonetes e pesque-pagues. Além disso, 45\% dessas empresas terceirizam parte de suas vendas e $5 \%$ vendem filé para a merenda escolar e para hotéis.

7) Dado que as empresas praticam preços muito próximos, que o produto é homogêneo e que os clientes são, predominantemente, famílias e empresas da iniciativa privada, não é comum que as compras sejam feitas mediante pesquisa de preços, prevalecendo a aceitação do produto pelos consumidores. No item anterior, constatou-se que, apenas uma empresa vende filé para a merenda escolar na rede pública de ensino, participando de processo licitatório para efetuar a venda.

\subsubsection{Políticas governamentais}

Em relação às políticas governamentais, um fator relevante que afeta a estrutura-conduta-desempenho da indústria no mercado estudado é a legislação sanitária vigente que regulamenta o beneficiamento, o processamento e a comercialização de produtos de origem animal. Os estabelecimentos que beneficiam, processam e comercializam o pescado precisam estar registrados junto ao Serviço de Inspeção Sanitária de Produtos de origem animal federal (SIF/POA) caso comercializem sua 
produção no mercado nacional e internacional, junto ao Serviço de Inspeção Sanitária Estadual (SIP/POA), quando comercializam no mercado estadual e junto à Inspeção Sanitária Municipal (SIM/POA), quando vendem sua produção apenas no mercado local ou municipal.

De acordo com o que foi mencionado no sub-item 5.1.1., em 1999, nenhuma das unidades de beneficiamento de pescado estabelecidas no Paraná possuíam o registro junto ao SIF/POA. Apesar do interesse e das constantes tentativas de algumas empresas em adequar sua planta industrial às exigências do SIF/POA, é preciso destacar que, do ponto de vista dos pequenos empresários do setor, o processo é burocrático e lento e os custos de adequação da estrutura produtiva são elevados. Constata-se, portanto, que no caso dos estabelecimentos que beneficiam no Paraná, a legislação sanitária tem restringido a expansão do mercado consumidor para fora do mercado estadual representando uma barreira à entrada de novas empresas neste mercado.

Cabe ressaltar, também, que a regulamentação da Superintendência de Desenvolvimento dos Recursos Hídricos e Saneamento Ambiental (SUDERHSA) e do Instituto Ambiental do Paraná (IAP), que torna obrigatória a outorga de autorização de uso de águas de domínio público tanto para empresas já instaladas quanto para as novas empresas pode representar uma barreira à entrada de novas empresas neste mercado, uma vez que, segundo a Instrução Normativa $N^{\circ}$ 003/98 de 06/06/1998, do SIP/POA, são necessários dez litros de água clorada (quente e fria) para cada quilo de pescado abatido. A grande quantidade de água potável necessária, normalmente, obriga as unidades de beneficiamento a utilizarem águas públicas, pois do contrário, seu custo se elevaria muito. Além disso, a disponibilidade de água passa a ser um fator tão importante quanto localização, energia elétrica, acesso aos centros consumidores na hora da compra do terreno para a instalação da empresa.

Outra legislação que tem influenciado o desempenho da agroindústria de pescado no Paraná é o Decreto No 4.621 de 27/07/98 da Secretaria da Fazenda do Estado do Paraná que estabelece a redução da base de cálculo do ICMS para 58,333\%, nas operações internas com peixe fresco, resfriado ou congelado. Desta forma, a alíquota 
normal de $12 \%$ fica reduzida para $7 \%$. Acredita-se que a redução deste tributo permite reduzir os custos da empresa e, conseqüentemente, o preço final do filé.

A redução da base de cálculo do ICMS para $40 \%$ nas operações com ração animal, concentrados ou suplementos, de acordo com o Decreto $\mathrm{N}^{\circ} 4.621$ de 27/07/98, representa um desconto de 7,2\% do ICMS na compra da ração para peixe beneficiando, diretamente, os piscicultores paranaenses que utilizam a ração industrializada na alimentação dos peixes e, indiretamente, a indústria que passa a receber uma matériaprima de melhor qualidade. A condição necessária para obter o desconto no ICMS pago na compra da ração é que o piscicultor seja filiado a alguma associação ou cooperativa de produtores rurais.

\subsubsection{Aspectos estruturais da indústria de beneficiamento de tilápia-do-nilo instalada no Estado do Paraná}

Neste item analisou-se a estrutura da indústria de beneficiamento de pescado de água doce criado em cativeiro no Estado do Paraná, observando-se as barreiras à entrada, a diferenciação e diversificação na produção, bem como a concentração nesta indústria.

\section{a) Barreiras à entrada de novas empresas}

Para identificar as barreiras à entrada na indústria estudada, segundo o ponto de vista dos empresários, incluiu-se no questionário uma pergunta, cujas respostas encontram-se sintetizadas na Tabela 20. Optou-se, ainda, por analisar separadamente as empresas com Licença do Serviços de Inspeção Sanitária Federal (SIF), Estadual (SIP) e aquelas que possuem Licença do Serviço de Inspeção Sanitária Municipal (SIM) uma vez que, as últimas operam em condições de mercados bem diferentes das primeiras e, portanto, enfrentam dificuldades também diferentes (Tabela 21). 
Tabela 20. Classificação das principais barreiras à entrada de novas empresas na indústria de beneficiamento de tilápias segundo empresários entrevistados

\begin{tabular}{lccc}
\hline Tipo de Barreira & Barreira Forte & Barreira Média & Barreira Fraca \\
\hline Acesso à matéria-prima & $59 \%$ & $12 \%$ & $29 \%$ \\
Investimento Inicial & $53 \%$ & $41 \%$ & $6 \%$ \\
Capital de Giro & $47 \%$ & $41 \%$ & $12 \%$ \\
Escala mínima da planta & $41 \%$ & $6 \%$ & $53 \%$ \\
Dificuldade de comercialização & $41 \%$ & $12 \%$ & $47 \%$ \\
Necessidade de Integração Vertical & $12 \%$ & $24 \%$ & $65 \%$ \\
Regulamentação Estatal & $6 \%$ & $47 \%$ & $47 \%$ \\
Falta de experiência & $6 \%$ & - & $94 \%$ \\
Falta de organização & $6 \%$ & - & $94 \%$ \\
Falta de Infra-estrutura & $6 \%$ & - & $94 \%$ \\
Acesso à tecnologia & - & $6 \%$ & $94 \%$ \\
\hline
\end{tabular}

Fonte: Dados da pesquisa.

De acordo com as dezessete empresas que responderam a esta questão, a principal barreira à entrada de novas empresas é o acesso à matéria-prima. Ou seja, 59\% destas empresas mencionaram o acesso à matéria-prima como uma forte barreira à entrada de novas empresas neste mercado. Esta informação está coerente com a resposta dada à questão de disponibilidade de matéria-prima, onde $45 \%$ dos entrevistados consideram a oferta de peixe vivo escassa e $45 \%$ consideram-na abundante. Ou seja, as empresas que apresentam maiores escalas de produção e recorrem ao mercado para obter o peixe vivo enfrentam a concorrência dos pesque-pagues que, durante o verão, pagam preços muito superiores aos da indústria, obrigando esta última a elevar o preço pago ao produtor para garantir a obtenção da matéria-prima (Tabela 20). 
Tabela 21. Classificação das principais barreiras à entrada de novas empresas na indústria de beneficiamento de tilápias segundo categorias de empresas

\begin{tabular}{|c|c|c|c|c|c|c|c|c|c|}
\hline \multirow[t]{2}{*}{ Tipo de barreiras } & \multicolumn{3}{|c|}{ Empresas com SIF } & \multicolumn{3}{|c|}{ Empresas com SIP } & \multicolumn{3}{|c|}{ Empresas com SIM } \\
\hline & Forte & Média & Fraca & Forte & Média & Fraca & Forte & Média & Fraca \\
\hline Integração Vertical & $50 \%$ & - & $50 \%$ & $14 \%$ & $43 \%$ & $43 \%$ & - & $12 \%$ & $88 \%$ \\
\hline Custo do Capital de Giro & - & $100 \%$ & - & $72 \%$ & $14 \%$ & $14 \%$ & $37,5 \%$ & $50 \%$ & $12,5 \%$ \\
\hline Regulamentação Estatal & - & $50 \%$ & $50 \%$ & $14 \%$ & $43 \%$ & $43 \%$ & - & $50 \%$ & $50 \%$ \\
\hline Acesso à matéria-prima & $100 \%$ & - & - & $71 \%$ & $14 \%$ & $14 \%$ & $37,5 \%$ & $25 \%$ & $37,5 \%$ \\
\hline Dificuldade de comercialização & $100 \%$ & - & - & $43 \%$ & $14 \%$ & $43 \%$ & - & $25 \%$ & $75 \%$ \\
\hline Escala mínima da planta & - & $50 \%$ & $50 \%$ & $57 \%$ & $14 \%$ & $29 \%$ & $25 \%$ & - & $75 \%$ \\
\hline Investimento inicial & - & $50 \%$ & $50 \%$ & $57 \%$ & $43 \%$ & - & $62,5 \%$ & $37,5 \%$ & - \\
\hline Falta de experiência & - & - & $100 \%$ & $14 \%$ & - & $86 \%$ & - & - & $100 \%$ \\
\hline Acesso à tecnologia & - & - & $100 \%$ & - & - & $100 \%$ & & $12,5 \%$ & $87,5 \%$ \\
\hline Falta de organização & - & - & $100 \%$ & - & - & $100 \%$ & $12,5 \%$ & - & $87,5 \%$ \\
\hline Falta de Infra-estrutura & - & - & $100 \%$ & - & - & $100 \%$ & $12,5 \%$ & - & $87,5 \%$ \\
\hline
\end{tabular}

Fonte: Dados da pesquisa.

Considerando os dados da Tabela 21, observa-se que este é um problema que afeta, principalmente, as empresas que atuam no mercado estadual e nacional, uma vez que $78 \%$ das nove empresas que afirmaram existir escassez de matéria-prima dependem do mercado para obter, em média, $94 \%$ da matéria-prima que necessitam. Desta forma, a questão é por que não internalizar a atividade? Por que não estabelecer contratos? Constatou-se através da pesquisa que, as empresas que produzem em maiores escalas consideram interessante verticalizar a produção estabelecendo contratos entre as unidades de beneficiamento e os piscicultores, no entanto, alegam custos muito elevados, escassez de capital de giro e riscos elevados em decorrência do comportamento oportunista dos piscicultores.

A questão da escassez de capital de giro é realmente um problema enfrentado pelas unidades de beneficiamento de tilápias, uma vez que se tratam de pequenas empresas familiares que, em geral, pertencem a pequenos produtores rurais, cuja principal atividade geradora de renda é a piscicultura e que, portanto, não possuem capital de giro próprio suficiente tendo que recorrer ao mercado financeiro. 
O capital de giro necessário ao processo produtivo, também foi citado por $47 \%$ dos entrevistados como uma forte barreira. Das dezesete empresas que responderam a questão, apenas seis informaram qual o valor médio mensal necessário para capital de giro em sua empresa, que varia entre $R \$ 10.000,00$ e $R \$ 150.000,00$. Analisando a Tabela 21, observa-se que este é um problema, principalmente, das empresas com SIP/POA que, em sua maioria, utilizam matéria-prima comprada e que possuem baixa capacidade de autofinanciamento, uma vez que são empresas muito pequenas.

Outra forte barreira à entrada de novas empresas na indústria de beneficiamento de tilápias, citada por $53 \%$ dos entrevistados, é o valor do investimento inicial para implantação da empresa (Tabela 20).

Da análise dos questionários, conclui-se que o investimento inicial necessário à instalação das unidades de beneficiamento de pescado variou de $R \$ 30.000,00$ a $R$ \$ 900.000,00 dependendo do tamanho da planta e das exigências estabelecidas pelo serviço de inspeção sanitária. Na opinião dos entrevistados estes valores representam uma forte barreira à entrada no mercado, uma vez que a maioria das firmas instaladas são empresas familiares de pequeno porte e de propriedade de pequenos produtores rurais. No entanto, provavelmente, estes valores não representariam uma forte barreira para grandes grupos econômicos que quisessem ingressar na referida indústria.

De acordo com a Tabela 21, observa-se que, enquanto o custo de implantação é uma forte barreira para a maioria das empresas com SIP e com SIM, é apenas uma média ou fraca barreira para a entrada de empresas com SIF. Na verdade, apesar das exigências da Legislação Sanitária Federal serem maiores em relação à Legislação Sanitária Estadual e dos Municípios, implicando em maiores despesas de implantação, as empresas com SIF estabelecidas no Estado pertencem a grupos de empresários, enquanto as empresas com SIP e SIM, em geral, pertencem a pequenos produtores rurais.

Embora as dificuldades na comercialização não sejam considerados fortes empecilhos pela maioria das empresários (Tabela 20), analisando a Tabela 21, observase que as empresas com SIF e SIP enfrentam dificuldades na comercialização da produção, classificando esta questão como uma forte barreira à entrada neste mercado, 
enquanto as empresas com SIM consideram-na uma fraca barreira. Isto se explica, uma vez que, as empresas com SIM comercializam apenas no mercado local e produzem quantidades muitos pequenas de filé, de forma que são pequenos os esforços requeridos para comercializar a sua produção. Já as empresas que atuam no mercado estadual e nacional concorrem entre si, obrigando-se a empreender maiores esforços na hora de comercializar a produção. Além disso, as empresas com SIP e SIF comercializam entre 50 e $80 \%$ de sua produção de filé junto aos supermercados e distribuidores atacadistas ficando em situação bastante vulnerável uma vez que não há uma dependência bilateral entre as partes.

É possível enumerar, em ordem decrescente, outros fatores que também foram mencionados com fortes obstáculos à entrada de novas firmas na referida indústria, tais como a escala mínima da planta, regulamentação estatal, a necessidade de integração vertical, a falta de experiência neste mercado, falta de organização das firmas do setor e a falta de infra-estrutura (estradas).

\section{b) Diferenciação e diversificação do produto}

A indústria de beneficiamento de tilápias-do-nilo criadas em cativeiro, instalada no Estado do Paraná, caracteriza-se por uma produção física pouco diferenciada e não diversificada.

A diferenciação pode resultar de uma mudança na natureza do produto, na forma de apresentação ao consumidor, melhorias da qualidade ou por marca registrada. No caso da indústria de beneficiamento de pescado analisada neste estudo, constata-se pela pesquisa realizada que o filé de tilápia é um produto homogêneo no que diz respeito às suas características físicas, químicas e nutricionais. Os principais fatores de diferenciação do produto estão relacionados à técnica de congelamento, embalagem e aparência do produto. Até maio/97, todas as empresas existentes no mercado embalavam o filé antes do resfriamento e congelamento em bandejas plásticas cobertas com plástico PVC-resinite com 500 e 1000 gramas, com etiquetas contendo informações da marca e produto ou em massinhos onde os filés são enrolados individualmente uns sobre os 
outros de forma que possam ser retirados um a um, mesmo depois de congelados. A partir de 1997, novas empresas que ingressaram no mercado passaram a embalar o produto em pacotes plásticos após o congelamento individual dos filés. Sem dúvidas, essa diferenciação foi bastante importante não somente pela melhor apresentação do produto e pela maior praticidade e conveniência, principalmente, para aqueles consumidores que preparam pequenas porções do produto como também para as empresas que a implementaram, pois tem permitido a cobrança de preços diferenciados.

A diversificação ocorre pela elaboração de produtos para diferentes mercados. De acordo com a pesquisa, constatou-se que as firmas paranaenses não diversificam a sua produção. Apesar de sete das dezoito empresas que responderam a esta questão possuírem interesse em elaborar uma linha de produtos processados ou semi-prontos a base de tilápia, tais como nugets, hamburguers, croquetes, filé empanado, etc, apenas uma delas já iniciou a produção de filés empanados. O motivo alegado pelas empresas para a não diversificação da produção são os elevados custos dos equipamentos necessários.

\section{c) Concentração de mercado}

A Tabela 22 mostra as razões de concentração para as oito maiores empresas (CR8), para as quatro maiores empresas (CR4) e para as duas maiores empresas (CR2) e o índice de Herfindahl-Hirschmann (HHI), calculados com base na produção artesanal e industrial de filé de tilápia ofertada no mercado paranaense por empresas estaduais e de outros estados, em 1999. Ainda, considerando que nem todas as empresas vendem sua produção em todas as regiões do Estado, ou seja, nem todas as empresas competem nos mesmos mercados, optou-se por calcular também as razões de concentração e o índice de Herfindahl-Hirschmann utilizando como base a quantidade de filé de tilápia comercializado pelas empresas em cada macrorregião do Estado. Além disso, pelo fato da produção informal ser realizada por um grande número de pequenos produtores e por não se conhecer esse número agregou-se a produção como se a produção clandestina fosse de uma única empresa. Desta forma, em alguns casos, a produção informal passa a 
representar uma parcela do mercado maior do que a atendida pela maior empresa da indústria como, por exemplo, no mercado estadual em que a produção informal agregada representa $31,9 \%$ do mercado enquanto a produção da maior empresa instalada representa apenas $26,7 \%$ do mesmo. Por isso, optou-se por calcular as razões de concentração, primeiro, não incluindo a produção clandestina pois esta representa a produção de um conjunto de pequenos produtores que produzem e comercializam, isoladamente, quantidades muito pequenas de filé de tilápia e que não possuem nenhum poder para influenciar o equilíbrio deste mercado. Posteriormente, as razões de concentração foram calculadas considerando a produção informal agregada como uma empresa.

Tabela 22. Resultados do Índice de Herfindahl-Hirschman (HHI) e das Parcelas de Mercado (CR8; CR4 e CR2) para o Estado do Paraná, tomando a produção anual de filé de tilápia no ano de 1999.

\begin{tabular}{lcccccccc}
\hline Mercado & \multicolumn{2}{c}{$\begin{array}{c}\text { Número de } \\
\text { Empresas }\end{array}$} & HHI & \multicolumn{2}{c}{ CR2 (\%) } & \multicolumn{2}{c}{ CR4 (\%) } & \multicolumn{2}{c}{ CR8 (\%) } \\
& \multicolumn{1}{c}{ (\%) } & & & & & & & \\
\hline Paraná & 20 & 0,227 & 0,372 & 0,586 & 0,479 & 0,745 & 0,593 & 0,889 \\
Oeste & 09 & 0,243 & 0,519 & 0,605 & 0,621 & 0,907 & 0,685 & 0,998 \\
Norte & 06 & 0,322 & 0,481 & 0,766 & 0,549 & 0,952 & - & - \\
Sudoeste & 12 & 0,182 & 0,447 & 0,481 & 0,698 & 0,790 & 0,763 & 0,960 \\
Noroeste & 05 & 0,308 & 0,629 & 0,675 & 0,673 & 0,982 & - & - \\
Sul & 09 & 0,357 & 0,710 & 0,710 & 0,848 & 0,868 & 0,917 & 0,991 \\
\hline
\end{tabular}

Fonte: Dados da pesquisa.

1. Foram consideradas todas as empresas que operavam, em 1999, e comercializavam sua produção no mercado estadual, sendo dezoito delas instaladas no Paraná e uma instalada em Santa Catarina. Por ser desconhecido o número de produtores artesanais, agregou-se toda a produção do Estado, considerando-se uma empresa.

Observa-se que no segundo caso, os valores encontrados para as razões de concentração são bem maiores devido à grande participação da produção informal em alguns mercados. No entanto, considerando que as parcelas elevadas de mercado do setor informal não representam poder de mercado, analisou-se apenas o primeiro caso. 
Analisando os dados da Tabela 22, constata-se que os valores encontrados para as razões de concentração - o CR8 de 59,3\%, indicando que as oito maiores empresas supriram praticamente $59 \%$ do consumo estadual de filé, o CR4 igual a 47,9\%, indicando que as quatro maiores empresas ofertaram aproximadamente $48 \%$ do filé de tilápia consumido no Paraná e CR2 igual 37,2\% indicando que as duas maiores empresas ofertaram cerca de $37 \%$ do filé consumido no estado, em 1999. A partir destes resultados conclui-se que a indústria de beneficiamento de tilápia no Paraná apresenta uma baixa concentração, o que explica o valor encontrado para o Índice de HirschmanHerfindahl $(0,227)$, ou seja, os valores encontrados para as razões de concentração permitem classificar a estrutura de mercado da referida indústria como atomizada. De acordo com Carlton \& Perloff (1991), este mercado pode ser classificado como uma competição monopolística, pois, embora existam muitas firmas no mercado, existem também algumas barreiras à entrada de novas empresas.

Esta conclusão fica ainda mais evidente se for levado em consideração que o HHI e as razões de concentração foram calculadas a partir da produção artesanal total, sem desagregá-la por produtores, uma vez que este número é bastante grande mas desconhecido. Em 1999, existiam 5.645 pesque-pagues em funcionamento em todo o Estado do Paraná, embora não se saiba, exatamente, quantos deles produziam e comercializavam filé de tilápia. De acordo com entrevistas realizadas junto aos coordenadores regionais da piscicultura da EMATER-Paraná, foram obtidos valores estimados da produção artesanal, por regiões, realizada tanto por pesque-pagues quanto por piscicultores isolados.

Ao analisar os indicadores calculados para as diferentes regiões do Estado percebe-se que os valores das razões de concentração variam de uma região para outra, indicando que os valores encontrados para o Paraná como um todo subestimam o poder de mercado eventualmente exercido por algumas empresas em mercado regionais.

Analisando primeiramente a Região Oeste do Paraná que, em 1999, contava com 8 empresas que operavam na produção industrial e um conjunto de produtores que elaboraram artesanalmente o filé de tilápia e que comercializaram sua produção no mercado regional, observa-se que as duas maiores empresas que operavam neste 
mercado detiveram aproximadamente $52 \%$ do mercado e que as quatro e oito maiores detiveram respectivamente, $62 \%$ e $69 \%$ do mercado (Tabela 22). Esses resultados aliados ao valor encontrado para o HHI indicam a existência de uma concentração moderada-alta neste mercado.

$\mathrm{Na}$ região Norte do Estado, onde cinco empresas operavam no mercado formal e um conjunto de produtores atuava cladestinamente no beneficiamento de tilápia, constatou-se a existência de uma concentração moderada uma vez que as duas maiores empresas que atuaram neste mercado ofertaram $48 \%$ do filé de tilápia consumido na região e as quatro maiores atenderam aproximadamente $55 \%$ do mercado regional. $\mathrm{O}$ valor encontrado para o HHI $(0,322)$ reflete a desigualdade existente e também o pequeno número de empresas que atuaram neste mercado. Na verdade, se fosse possível desagregar a produção informal por produtor o HHI seria muito menor. Enquanto as duas maiores empresas detiveram $48 \%$ o conjunto de pequenos produtores que operaram no mercado informal ofertaram aproximadamente $43 \%$ do filé consumido na região, em 1999 (Tabela 22). No entanto, apesar da produção artesanal ter representado $43 \%$ da quantidade total consumida na região Norte não pode ser considerado como um indicativo de concentração de mercado, pois representou a produção de muitos e pequenos produtores que operaram neste mercado naquele ano.

Com relação à região Sudoeste, onde onze unidades de beneficiamento com SIP e SIM e um conjunto de produtores que operavam no mercado informal comercializaram filé, em 1999, os valores obtidos para as razões de concentração - CR2 de 44,7\%, CR4 igual 69,8\% e CR8 de 76,3\% - indicam a existência de concentração moderada-alta (Tabela 22). O valor do $\mathrm{HHI}$ encontrado se deve ao número maior de empresas, bem como a baixa desigualdade entre elas. Neste caso, o setor informal respondeu por $20,9 \%$ da produção consumida na região.

$\mathrm{Na}$ região Noroeste, onde apenas quatro empresas que operam no mercado formal de beneficiamento de tilápias e um conjunto de produtores que produziam filé artesanalmente comercializaram o produto, constatou-se a existência de uma alta concentração de mercado. Ou seja, as duas e quatro maiores empresas detiveram respectivamente, $63 \%$ e $70 \%$ do mercado regional em 1999 , conforme tabela 22 . O valor 
mais elevado obtido para o HHI se explica, neste caso, tanto pela alta concentração e participação desigual das empresas neste mercado quanto pelo seu reduzido número, uma vez que a produção informal de muitos pequenos produtores foi agregada como se fosse uma única empresa.

No caso da região Sul, nove empresas oficialmente estabelecidas e um conjunto de pequenos produtores que atuavam no mercado informal comercializaram filé de tilápia em 1999. Os valores encontrados para as razões de concentração - CR2 de 71\%, CR4 de $85 \%$ e CR8 igual a $92 \%$ - aliado ao valor encontrado para o HHI permitem concluir que este mercado é altamente concentrado. Analisando as razões de concentração acima descritas (ver Tabela 22), observa-se que as parcelas de mercado das empresas são muito desiguais, o que explica o HHI mais elevado, ou seja, a maior empresa deteve sozinha $56 \%$ do mercado regional, enquanto a segunda maior e a terceira maior atenderam, respectivamente, $14,8 \%$ e $7,6 \%$ daquele mercado.

Ao finalizar esta análise é possível concluir que as condições básicas de oferta e demanda influenciam a estrutura deste mercado. A inexistência de uma associação de classe que caracteriza a ação isolada e pouco organizada das empresas no mercado, a tecnologia de produção similar e acessível, o produto homogêneo e com preço pouco competitivo em relação aos produtos substitutos, a ausência de coordenação da produção de matéria-prima por parte da indústria são fatores que têm facilitado a entrada de novas empresas, tanto no mercado formal quanto no informal. Observa-se, que elementos institucionais, tais como, a elevada carga tributária, a sensibilidade do consumidor em relação aos preços do filé, o costume de comprar peixe sem se preocupar com a sanidade e a fiscalização que concentra seus esforços nos estabelecimentos legalizados também têm facilitado o surgimento e manutenção dos produtores clandestinos de filé de tilápia.

Como conseqüência, tem-se uma estrutura de mercado atomizada e pouco concentrada, onde um grande número de empresas pouco agressivas produzem em baixa escala, com altos custos praticando preços muito elevados e pouco competitivos se comparados com os preços de outras carnes. 


\subsection{A conduta da indústria paranaense de beneficiamento de tilápia-do-nilo}

De acordo com o paradigma estrutura-conduta-desempenho espera-se que, no curto prazo, a estrutura da indústria de beneficiamento de pescado determine a conduta das firmas e que os elementos de conduta se autodeterminem.

Assim sendo, neste item procurou-se analisar a maneira pela qual as condições básicas de oferta e demanda, as políticas governamentais e a estrutura de mercado influenciam (e como podem ser influenciadas) pela conduta das firmas de beneficiamento de pescado, no que diz respeito à determinação dos preços e quantidades a serem produzidas, a existência de competição via preço ou extra-preço, estratégias de inovação de processos e melhoria da qualidade do produto e do grau de articulação entre as empresas.

\subsubsection{Critérios para determinação dos preços do filé de tilápia pelas empresas beneficiadoras}

O preço do filé de tilápia é, de modo geral, fixado a partir da sugestão inicial das unidades beneficiadoras. De acordo com as 20 empresas que responderam a esta questão, constata-se que $35 \%$ das empresas fixam, inicialmente, o preço do filé. No

entanto, $85 \%$ destas firmas afirmaram que no caso de vendas para as grandes redes de supermercados e para empresas especializadas na distribuição de pescado, acaba prevalecendo a negociação entre produtores e compradores. Com relação às outras empresas, verificou-se que tomam o preço no mercado, conforme Tabela 23.

Constata-se que, apesar de algumas empresas liderarem este mercado, fixando e ditando preços, a política predominante é a negociação entre vendedores e compradores. Esta conduta decorre da estrutura atomizada e da baixa concentração deste mercado, ou seja, o fato de existir um grande número de empresas, que ofertam o produto no mercado estadual, reduz o poder de barganha destas empresas, estabelecendo uma relação de dependência unilateral entre indústria e distribuidores atacadistas e varejistas. 
Essa situação fica mais evidente quando verifica-se que $33 \%$ das empresas com SIP e $100 \%$ das empresas com SIF, em geral, fixam preço, embora negociem com os grandes compradores.

Tabela 23. Formas de fixação de preço do filé na indústria de beneficiamento de tilápia no Estado do Paraná.

\begin{tabular}{lc}
\hline Critério de Fixação do Preço do Filé de Tilápia & $\%$ \\
\hline Fixa e ou negocia o preço com o comprador & $35 \%$ \\
Toma o preço no mercado & $65 \%$ \\
Total & $100 \%$ \\
\hline
\end{tabular}

Fonte: Dados da pesquisa.

No caso das empresas com SIM, apenas uma delas (12,5\%) afirmou que fixa o preço do seu produto. Esta conduta se explica pelo fato da empresa estar situada em um município colonizado por orientais, onde comercializa todo o filé de tilápia produzido resfriado para elaboração de pratos da culinária japonesa, diretamente com os consumidores finais em uma feira livre. Neste caso, observa-se que a empresa especializou-se no atendimento de um público específico que, provavelmente, está disposto a pagar mais pelo produto diferenciado.

\subsubsection{Acordos, contratos e fusões na indústria paranaense de beneficiamento de tilápia}

Pelo fato da indústria paranaense de beneficiamento de tilápia ter uma estrutura considerada atomizada, verifica-se que apenas $35 \%$ das empresas estabelecidas no Estado e entrevistadas se enquadram como fixadoras de preços, não havendo acordos entre as empresas beneficiadoras de pescado. 
Também não há nessa indústria a presença de contratos escritos, o que pode ser explicado pela estrutura do mercado de insumos. Apesar de $40 \%$ das empresas regularmente estabelecidas no Paraná, considerarem interessante a integração vertical entre a indústria e o produtor, atualmente nenhuma delas trabalha em sistema de integração com o mercado fornecedor de matéria-prima, alegando os altos custos do capital de giro necessário.

É importante destacar que uma das empresas entrevistadas trabalhou em regime de cooperação vertical com os piscicultores, durante os anos de 1995 e 1996, mediante contrato, no qual a empresa adiantava alevinos para o cultivo e fornecia assistência técnica mensal gratuita e o produtor comprometia-se a comercializar sua produção com a empresa. No entanto, de acordo com o sócio-gerente entrevistado, a empresa abandonou o sistema de cooperação vertical, devido aos altos custos de capital de giro necessário para adiantar a ração e os alevinos aos produtores. Ainda, outro fator que levou a empresa a abandonar o sistema de cooperação vertical, segundo o gerente, foi o alto risco de não obter a matéria-prima necessária em decorrência do comportamento oportunista de parte dos piscicultores contratados que acabavam vendendo parte da produção e, em alguns casos, toda a produção aos pesque-pagues, pois estes lhes pagam preços superiores pelo quilo de tilápia viva.

De acordo com um estudo realizado por Libardi et al (1996), para viabilizar a instalação de uma processadora com SIF que operasse em regime de cooperação vertical com os fornecedores de matéria-prima, o preço pago ao produtor por quilo de tilápia viva poderia ser, no máximo, $R \$ 0,60$, enquanto o preço pago por quilo de tilápia pelos pesque-pagues varia entre $R \$ 1,00$ e $R \$ 1,50$. Essa situação obriga a indústria a obter a matéria-prima necessária via mercado pagando em torno de $\mathrm{R} \$ 0,95 / \mathrm{kg}$ de tilápia viva.

De acordo com Rissato (2001), apesar de formas organizacionais híbridas serem mais interessantes para a indústria de beneficiamento, pois isto lhe daria maior controle sobre a quantidade e qualidade da matéria-prima, este regime não interessa aos produtores que precisam buscar meios alternativos e até mais rentáveis para comercializar sua produção tendo em vista os altos custos de produção, principalmente, com ração para peixe. Desta forma, fica caracterizada uma dependência unilateral, em 
que o produtor não tem na indústria sua única possibilidade de comercialização da produção, mas esta sim depende do produtor para operar. Este fato explica as relações esporádicas e não duradouras via mercado entre piscicultores e unidades de beneficiamento, ou seja, o fato de não existir uma dependência bilateral entre as partes envolvidas, explica porquê, apesar da existência de especificidades de ativos ${ }^{10}$, ainda não são adotados contratos de médio e longo prazo entre a indústria e os fornecedores de matéria-prima.

A adoção de formas híbridas ou hierárquicas de governança, tende a ocorrer à medida que aumentar a produção de peixe cultivado nos Estados de São Paulo e Minas Gerais que são os principais compradores de peixe vivo produzido no Paraná. A maior disponibilidade de matéria-prima no estado do Paraná aumentaria a dependência dos produtores em relação à indústria.

Aliado a isso, seria necessário expandir o mercado consumidor atingindo volumes de produção que viabilizassem os investimentos necessários para diversificar e diferenciar a produção, permitindo a obtenção de economias de escala e de escopo. Cabe lembrar que, somente no ano 2000 , três unidades de beneficiamento de tilápias começaram a operar com o Serviço de Inspeção Sanitária Federal, uma delas já operava no mercado estadual com Serviço de Inspeção Sanitária Estadual e as outras foram inauguradas em junho e dezembro de 2000.

\subsubsection{Estratégias de ação das empresas em relação aos concorrentes}

Ao avaliar aspectos da conduta das unidades de beneficiamento de pescado em relação aos concorrentes, observa-se que tanto a competição via-preço (redução de preços), quanto a extra-preço (propaganda, diferenciação do produto, etc) são pouco expressivas.

\footnotetext{
${ }^{10}$ Segundo Williamson (1991, p.105) a especificidade dos ativos refere-se "ao grau no qual o ativo pode ser reempregado em usos alternativos e por usuários alternativos sem sacrifício de seu valor".
} 
De acordo com as empresas que funcionam com autorização do Serviço de Inspeção Sanitária Municipal (SIM) e que responderam o questionário, constata-se que a maioria das unidades de beneficiamento se preocupa muito pouco com os concorrentes. Isto se deve ao fato de serem "tomadoras de preço" e produzirem, apenas, o suficiente para manter seus clientes no mercado local. No entanto, $67 \%$ das empresas com SIF e $56 \%$ das empresas com SIP reduzem sua margem de lucro para manter o preço nominal do filé estável. Ainda, cabe destacar que $11 \%$ das empresas que operam no mercado estadual afirmaram que reduzem custos para baixar ou manter o preço do filé de tilápia (Tabela 24). É importante destacar que, quando a empresa, anteriormente citada (subitem 5.2.2), abandonou o sistema de cooperação com os piscicultores, deixando de oferecer insumos (alevinos, assistências técnica e, em alguns casos, ração) aos seus fornecedores de peixe vivo, na verdade, estava reduzindo custos para manter o preço do filé nos níveis praticados pelos concorrentes.

No que diz respeito ao controle de qualidade, também observa-se um maior rigor e controle por parte das empresas com SIP e SIF que operam no mercado estadual e nacional, podendo-se destacar como principais estratégias adotadas o controle do tamanho, cheiro e ou sabor do filé, o treinamento do público interno e externo das empresas e testes laboratoriais para avaliar as propriedade químicas e físicas do produto. No entanto, o único aspecto que parece preocupar a grande maioria das empresas, inclusive aquelas que operam apenas nos mercados locais, é o cheiro e ou sabor do filé de tilápia. Observa-se que $87,5 \%$ das empresas com SIM e $100 \%$ das empresas com SIP e SIF realizam o controle do cheiro e sabor do filé através da depuração do peixe vivo. Este procedimento, naturalmente, é muito importante, pois permite diagnosticar qualquer cheiro ou sabor (por exemplo, gosto de barro) que possa comprometer a qualidade do produto. No entanto, esta é uma exigência da Inspeção Sanitária e não propriamente uma iniciativa das empresas (Tabela 24). 
Tabela 24. Porcentagem de empresas da indústria paranaense de beneficiamento de tilápias-donilo que adotam estratégias de concorrência e a frequiência com que são adotadas

\begin{tabular}{|c|c|c|c|c|}
\hline \multirow[t]{2}{*}{$\begin{array}{l}\text { Estratégias de ação adotadas em } \\
\text { relação ao concorrentes }\end{array}$} & \multicolumn{3}{|c|}{$\begin{array}{l}\text { Porcentagem de empresas que já } \\
\text { adotaram a estratégia }\end{array}$} & \multirow{2}{*}{$\begin{array}{l}\text { Freqüência com } \\
\text { que são adotadas } \\
\text { as estratégias }\end{array}$} \\
\hline & $\begin{array}{l}\text { Empresas } \\
\text { com SIF }\end{array}$ & $\begin{array}{l}\text { Empresas } \\
\text { com SIP }\end{array}$ & $\begin{array}{l}\text { Empresas } \\
\text { com SIM }\end{array}$ & \\
\hline \multicolumn{5}{|l|}{ COMPETIÇÃO VIA PREÇO } \\
\hline Nenhuma & $33 \%$ & $33 \%$ & $87,5 \%$ & - \\
\hline Redução de custos & - & $11 \%$ & - & Quando necessário \\
\hline Redução da margem de lucro & $67 \%$ & $56 \%$ & $12,5 \%$ & Quando necessário \\
\hline COMPETIÇÃO EXTRA-PRECO & & & & \\
\hline Nenhuma & - & - & $12,5 \%$ & \\
\hline \multicolumn{5}{|l|}{$\begin{array}{l}\text { Melhoria na qualidade do produto } \\
\text { através de: }\end{array}$} \\
\hline - Controle do tamanho do filé & $67 \%$ & $56 \%$ & $25 \%$ & Diariamente \\
\hline - Controle do sabor/cheiro do & $100 \%$ & $100 \%$ & $87,5 \%$ & Esporadicamente \\
\hline filé & $67 \%$ & $33 \%$ & $12,5 \%$ & Esporadicamente \\
\hline - Testes laboratoriais do fillé & $33 \%$ & $22 \%$ & - & Uma vez \\
\hline - Inovações na produção & $33 \%$ & $44 \%$ & - & Uma vez \\
\hline - Inovações na conservação & $100 \%$ & $33 \%$ & - & Esporadicamente \\
\hline $\begin{array}{l}\text { - Treinamento de funcionários } \\
\text { - Treinamento de piscicultores }\end{array}$ & $67 \%$ & $11 \%$ & - & Esporadicamente \\
\hline \multicolumn{5}{|l|}{$\begin{array}{l}\text { Promoção de vendas, propaganda } \\
\text { e publicidade }\end{array}$} \\
\hline - Degustação do produto & $33 \%$ & $11 \%$ & - & Esporadicamente \\
\hline - Brindes & $33 \%$ & $22 \%$ & - & Esporadicamente \\
\hline - Doações e patrocínios & $100 \%$ & $100 \%$ & $12,5 \%$ & Esporadicamente \\
\hline - Propaganda & $33 \%$ & $44 \%$ & - & Semanalmente \\
\hline - Inovações na Embalagem & $67 \%$ & - & - & Uma vez \\
\hline
\end{tabular}

Fonte: Dados da pesquisa. 
Com relação às campanhas mercadológicas, observa-se que, apesar do filé de tilápia ainda ser um produto relativamente novo e pouco conhecido, são raras e bastante tímidas as iniciativas no sentido de divulgar a marca e o produto através de propaganda. As estratégias mais utilizadas são a publicidade (doações e patrocínios) e, no caso específico das empresas com SIF, as mudanças nas embalagens, em geral, decorrentes de inovações no processo de produção e conservação do produto. No entanto, campanhas de degustação do produto que, em geral, são bastante utilizadas nestas situações, ainda são muito pouco utilizadas pelas unidades de beneficiamento de tilápias do Paraná.

\subsubsection{Informações sobre o mercado concorrente}

Observa-se que a maioria das unidades de beneficiamento possui uma quantidade média de informação sobre os preços, as quantidades produzidas e vendidas, os fornecedores e os principais compradores dos concorrentes.

Tabela 25. Informação sobre os concorrentes no mercado de filé de tilápia

\begin{tabular}{lcccc}
\hline & Nenhuma & Pouca & Média & Bastante \\
\hline Empresas com SIF & - & - & $33 \%$ & $67 \%$ \\
Empresas com SIP & $11 \%$ & $33 \%$ & $55 \%$ & - \\
Empresas com SIM & $75 \%$ & $25 \%$ & - & - \\
\hline
\end{tabular}

Fonte: Dados da Pesquisa.

De acordo com as respostas obtidas nos questionários e resumidas na Tabela 25 , verifica-se que o nível de informação sobre o mercado e concorrentes aumenta no caso das empresas que atuam no mercado estadual e nacional.

Observa-se que $75 \%$ das empresas com SIM afirmaram não ter nenhuma informação sobre os seus concorrentes, enquanto 55\% das empresas com SIP e 67\% das 
empresas com SIF afirmaram conhecer bem ou bastante os seus concorrentes. Esta conduta se explica pela estrutura atomizada e pelo baixo poder de mercado das empresas, o que obriga as empresas maiores a competirem entre si tendo, portanto, a necessidade de identificar seus principais concorrentes e suas estratégias a fim de minimizar suas dificuldades na comercialização. Ou seja, observa-se que, neste caso, apesar da ausência de acordos formais e informais entre as empresas, elas procuram conhecer o mercado em que estão inseridas, com o objetivo de prever a reação dos seus concorrentes diante de suas estratégias de mercado.

Constata-se também que a falta de informação sobre o mercado concorrente, no caso das empresas com SIM, se explica, principalmente, devido à facilidade encontrada pelas pequenas empresas em vender seu produto, conforme foi mencionado na tabela 21 (sub-item 5.1.4), pois além das empresas municipais produzirem quantidades muito pequenas de filé, possuem um mercado consumidor que se restringe ao município em que está sediada, onde acabam atendendo a segmentos específicos que, em geral, não são atingidos pelas outras empresas maiores.

\subsubsection{Estratégias de distribuição e vendas}

A tabela 26 , a seguir, mostra as principais estratégias de vendas adotadas pelas empresas para comercializar o filé de tilápia.

De acordo com as respostas obtidas nos questionários e expostas na Tabela 26, nota-se que as empresas realizam suas vendas de várias formas, embora as principais sejam as vendas diretas ao consumidor $e$ as vendas sob encomenda ou mediante um contrato informal (pedido prévio), predominando a venda impessoal. Este último caso ocorre com compradores fixos que possuem datas de entrega e quantidades definidas, ou que, na hora em que recebem a mercadoria, já realizam outra compra para entrega futura. 
Tabela 26. Formas de comercialização do filé de tilápia

\begin{tabular}{lcccc}
\hline Formas de Comercialização & $\begin{array}{c}\text { Empresas } \\
\text { com SIM }\end{array}$ & $\begin{array}{c}\text { Empresas } \\
\text { com SIP }\end{array}$ & $\begin{array}{c}\text { Empresas } \\
\text { com SIF }\end{array}$ & $\begin{array}{c}\text { Média na } \\
\text { Indústria }\end{array}$ \\
\hline Televendas & $25 \%$ & $44 \%$ & $100 \%$ & $45 \%$ \\
Vendas Terceirizadas & - & $67 \%$ & $100 \%$ & $45 \%$ \\
Encomendas & $100 \%$ & $100 \%$ & $100 \%$ & $100 \%$ \\
Vendas Diretas ao Consumidor & $100 \%$ & $78 \%$ & $33 \%$ & $90 \%$ \\
Pronta entrega & $12,5 \%$ & $33 \%$ & $67 \%$ & $30 \%$ \\
\hline
\end{tabular}

Fonte: Dados da pesquisa.

Se essa análise for feita por categoria de empresa, observa-se também que os esforços para fazer o produto chegar ao consumidor são muito maiores no caso das empresas com SIF e SIP. As empresas com SIM realizam a maioria de suas vendas ao consumidor e ou sob encomenda, mantendo contato direto com seus clientes. Esta estratégia é importante, pois possibilita à empresa uma troca direta e simultânea de informações com o mercado consumidor do seu produto. No entanto, esta prática somente é possível porque, em geral, a produção dessas empresas é pequena e irregular.

As empresas com SIP e, especialmente, aquelas que possuem SIF, optam pelas estratégias de venda que lhe dão maior amplitude de mercado, tais como televendas, vendas terceirizadas, sob encomenda e pronta entrega. As formas de venda adotadas por estas empresas decorrem da estrutura atomizada deste mercado e das dificuldades e riscos inerentes à comercialização do filé de tilápia, pois assim podem planejar a sua produção, no curto prazo. Além disso, a contratação de empresas especializadas para distribuir o filé de tilápia também é uma forma de reduzir as despesas com mão-de-obra, encargos sociais e manutenção de veículos (Tabela 26).

Em síntese, é possível concluir que existe uma relação de reciprocidade entre as condições básicas de oferta e demanda, a estrutura atomizada e pouco concentrada e a conduta pouco agressiva da referida indústria. A ação isolada e pouco organizada das empresas, a baixa capacidade de autofinanciamento, a ausência de acordos e contratos 
que visem coordenar a produção e a falta de estratégias competitivas resultam em escassez de matéria-prima, vulnerabilidade das empresas junto aos fornecedores, distribuidores e concorrentes (pesque-pagues) que, por sua vez, podem se refletir no desempenho insatisfatório do setor.

\subsection{Desempenho da indústria paranaense de beneficiamento de tilápias-do-nilo}

Neste item pretende-se avaliar o desempenho da indústria de beneficiamento de tilápias-do-nilo do Estado do Paraná através da análise da evolução dos preços praticados pela indústria na comercialização do produto principal (filé de tilápia), evolução das margens de comercialização dos filé de tilápia, evolução da produção de filé de tilápia, a produtividade média da indústria bem como, sua capacidade ociosa.

\subsubsection{Evolução dos preços praticados pela indústria na venda do filé de tilápia.}

Para avaliar os níveis de preços praticados pela indústria de beneficiamento de pescado aqui estudada, considerou-se os preços reais de venda do filé de tilápia. Considerando a recente instalação da indústria de beneficiamento de pescado no Estado do Paraná e a inexistência de fontes secundárias, foram utilizados dados de preços fornecidos por duas empresas ${ }^{11}$. Os dados referem-se aos preços médios mensais praticados no período de setembro de 1995 a setembro de 2000, sendo que em uma das empresas foram coletados os preços de todo o período e, na outra, foram considerados apenas os preços a partir de maio de 1997, data em que a empresa começou a operar no mercado. Os preços nominais do filé de tilápia foram deflacionados pelo IGP-DI, base de junho/2001.

\footnotetext{
${ }^{11}$ Cabe destacar que, os dados de preços foram solicitados a todas as empresas entrevistadas. No entanto, apenas duas empresas forneceram os preços médios mensais praticados.
} 
A figura 5 ilustra o comportamento dos preços do filé de tilápia ao longo do período acima citado. Observa-se que os preços reais praticados pelo atacado (neste caso, as próprias unidades de beneficiamento) apresentaram um comportamento relativamente estável, com uma tendência de declínio no período analisado.
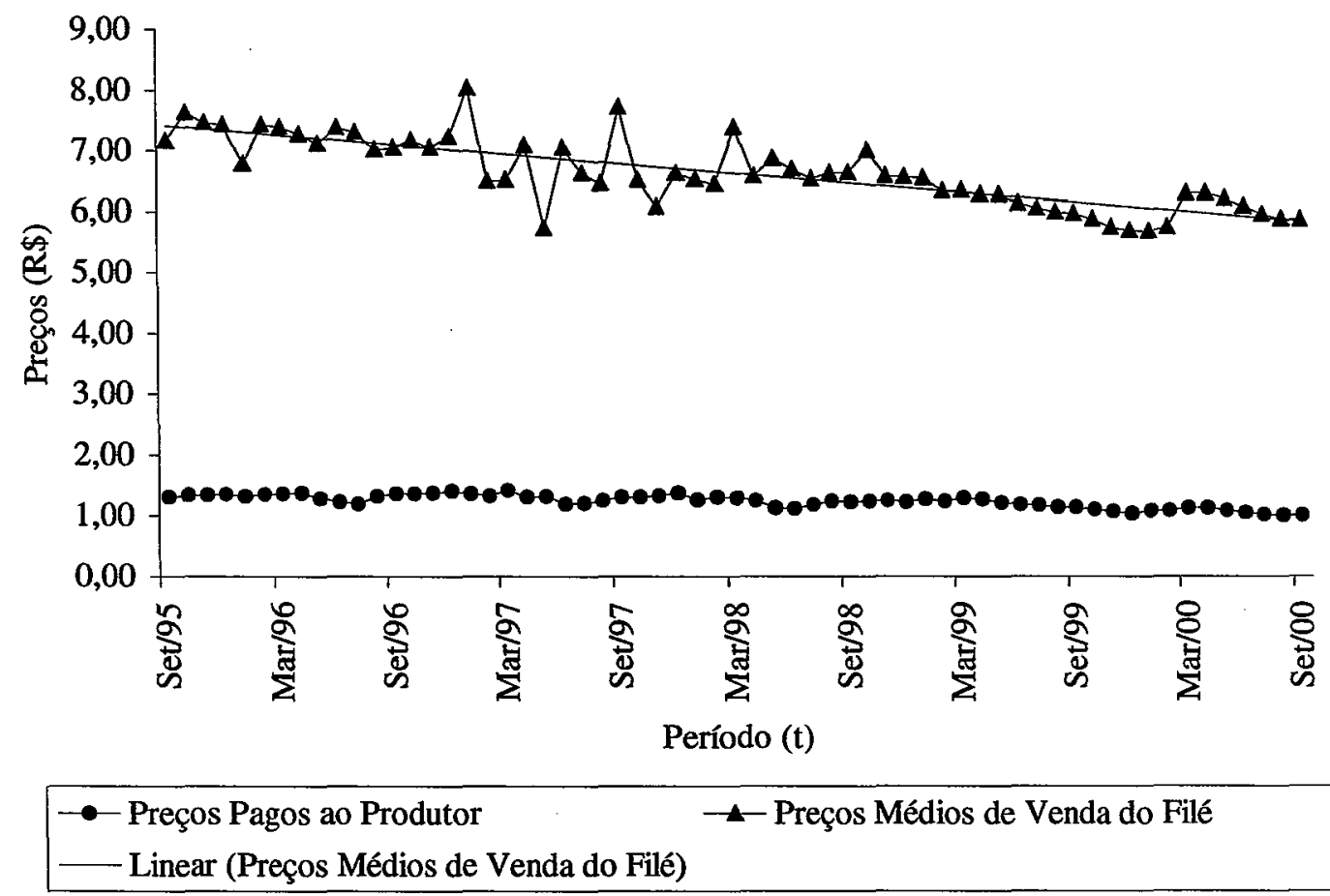

Figura 5 - Evolução dos preços do filé de tilápia no período de set/1995 a set $/ 2000$

Observa-se que até dezembro de 1996, os preços do filé mantiveram um comportamento bastante estável, dado que neste período apenas duas empresas estavam operando, sendo que uma delas monopolizava o mercado estadual. Durante o ano de 1997, observa-se a ocorrência de oscilações nos preços do filé, com uma tímida tendência de queda nos preços. Em maio de 1997, observa-se uma grande redução do preço de venda do filé. Isto se explica, provavelmente, pelo fato de ocorrer, todos os anos, uma redução na demanda de filé no mês subseqüente à quaresma. Além disso, essa redução nos preços, provavelmente, esteve associada à entrada de novas e importantes 
empresas no mercado em condições semelhantes à da empresa líder já instalada, e não às variações nos custos de produção, uma vez que o preço recebido pelo produtor permaneceu, praticamente, estável no período. Nesse ano, quatro novas empresas entraram no mercado (três empresas com SIP e uma empresa com SIM), sendo que a maior delas se instalou na região Oeste do Estado, começando a funcionar justamente no mês de maio, onde já operava a empresa que, até então, liderava o mercado.

A partir do quarto trimestre de 1997, os preços se estabilizam apresentando uma tendência de redução, com exceção do meses de março/1998 e março e abril/2000, em que ocorreram elevações no preço do filé em resposta ao aumento da quantidade demandada durante a quaresma. Esta tendência de baixa dos preços do filé de tilápia se explica, principalmente, pelo aumento do número de unidades de beneficiamento de tilápias em todo o Estado e pelo conseqüiente aumento da oferta do produto, conforme Figura 5.

Analisando as margens mensais de comercialização do filé de tilápia no período de setembro/1995 a setembro/2.000, observa-se que a margem de comercialização absoluta do atacadista oscila bastante, apresentando uma tendência decrescente ao longo do período, tanto no caso em que há o aproveitamento dos subprodutos, quanto no caso em que eles são descartados.

A tendência decrescente das margens totais absolutas pode ser explicada pela tendência de queda nos preços do filé no atacado, conforme pode ser observado na Figura 6. Isto se explica pelo aumento do número de empresas na indústria de beneficiamento de tilápias em todo o Estado do Paraná ao longo do período estudado e pela estrutura atomizada deste mercado.

De acordo com Marques \& Aguiar (1993, p.151), para produtos idênticos, quanto mais competitivo o mercado, menor deve ser a margem de comercialização. Além disso, o aumento da quantidade ofertada pela indústria no período tem aumentado o poder de barganha dos varejistas, pressionando $o$ preço do atacadista. 


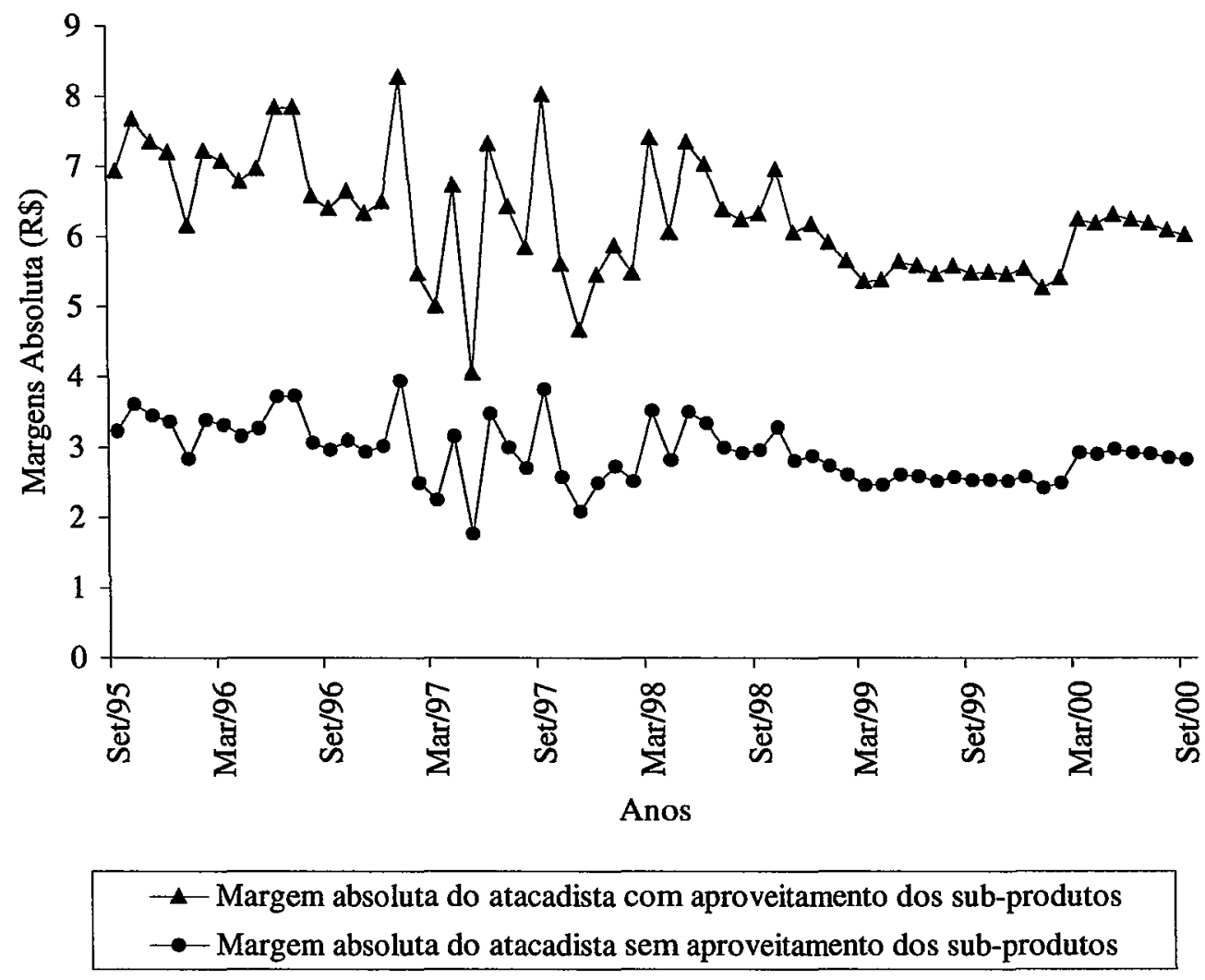

Figura 6 - Margem absoluta do atacadista na comercialização do filé de tilápia no período de setembro/1995 e setembro/2000.

Outro fator importante para explicar a redução das margens de comercialização é a existência de produtos concorrentes do filé. Mesmo quando o custo da matéria-prima aumenta, as empresas se obrigam a manter os preços de venda no atacado tendo em vista não apenas o grande número de unidades de beneficiamento de tilápia que ofertam nos mercados regionais e estadual, mas também pelo fato de existirem produtos substitutos, especialmente, para os extratos de renda mais baixa, como é caso do frango.

Observa-se também que a margem relativa do atacadista aumenta quando este comercializa os sub-produtos do peixe tais como o petisco, a pele e farinha de peixe produzida com a carcaça, reduzindo-se, conseqüentemente, a participação relativa do 
produtor no preço do filé (Figuras 7 e 8). As margens relativas de comercialização da indústria no período estudado foram, em média, de 50,37\% caso fossem aproveitados os resíduos do peixe e 43,93\% quando os resíduos são descartados.

Torna-se interessante citar, neste contexto, alguns resultados de margens calculadas em estudos realizados por outros autores a fim de compará-los com este trabalho.

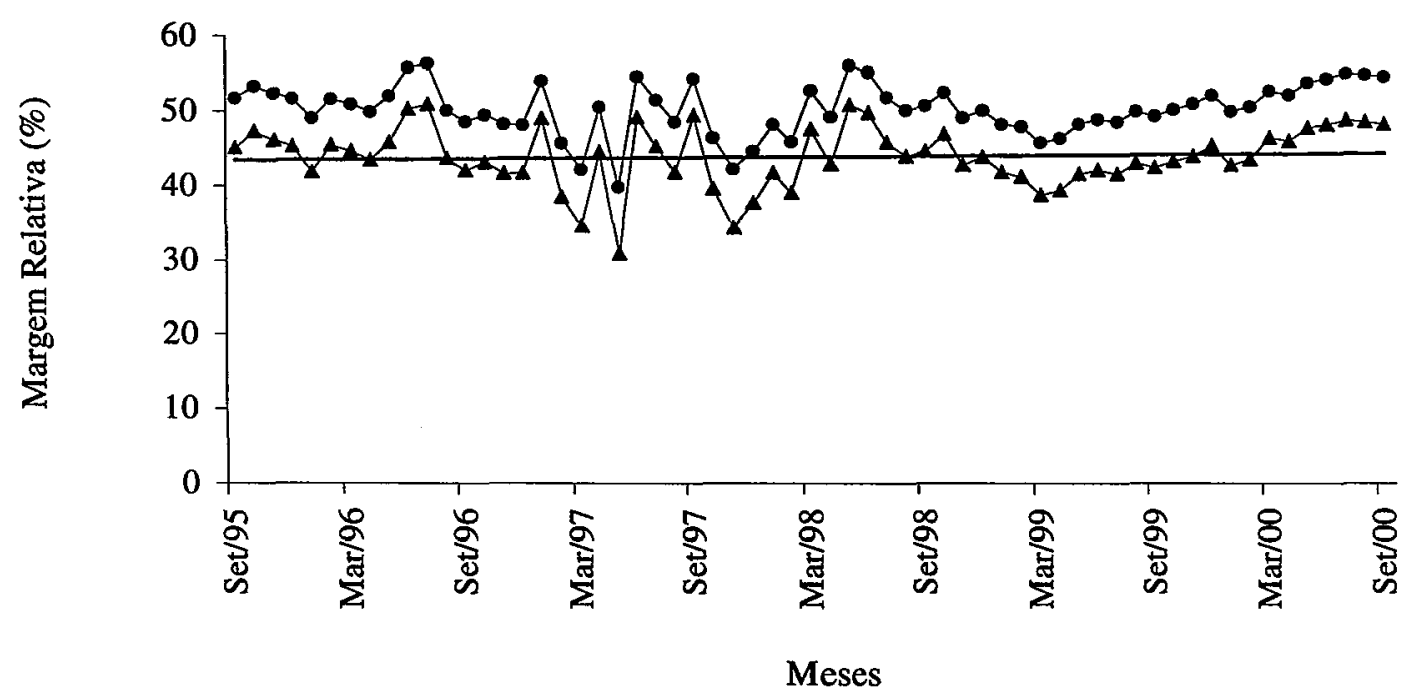

—- Margem relativa da indústria sem aproveitamento dos sub-produtos - Margem relativa da indústria com aproveitamento dos sub-produtos - Linear (Margem relativa da indústria sem aproveitamento dos sub-produtos)

Figura 7 - Margem relativa do atacadista na comercialização do filé de tilápia no período de setembro/1995 e setembro/2000.

Rissato \& Marques (1999), ao calcular as margens de comercialização da indústria de beneficiamento de tilápia instalada na região Oeste do Paraná, encontraram resultados muito próximos aos obtidos neste trabalho, em que a margem relativa de comercialização da indústria era de $54,47 \%$ quando eram utilizados os sub-produtos do peixe e de $42,21 \%$ nos casos em que eram descartados.

No trabalho realizado por Martin (1998), calculou as margens relativas de comercialização entre pescadores-colônia para 12 espécies capturadas no reservatório da 
Usina Hidrelétrica de Itaipu, no Paraná, encontrando valores que variam entre $12,5 \%$ e $38 \%$. Neste caso, as margens do atacadista são menores, pois ele se limita a revender o produto sem submetê-lo a qualquer processo de beneficiamento e ou transformação.

A elevada participação do produtor no preço do filé no atacado pode ser explicada pelo preço elevado da matéria-prima básica (peixe vivo), bem como pelo fato do filé de tilápia ser um produto pouco elaborado. É importante destacar que as menores participações relativas dos produtores ocorrem durante $\mathrm{o}$ outono $\mathrm{e}$ inverno, principalmente no mês de junho, quando os pesque-pagues saem do mercado e a indústria, normalmente, reduz a produção em resposta à retração no consumo, pressionando os preços pagos aos produtores (Figura 8).

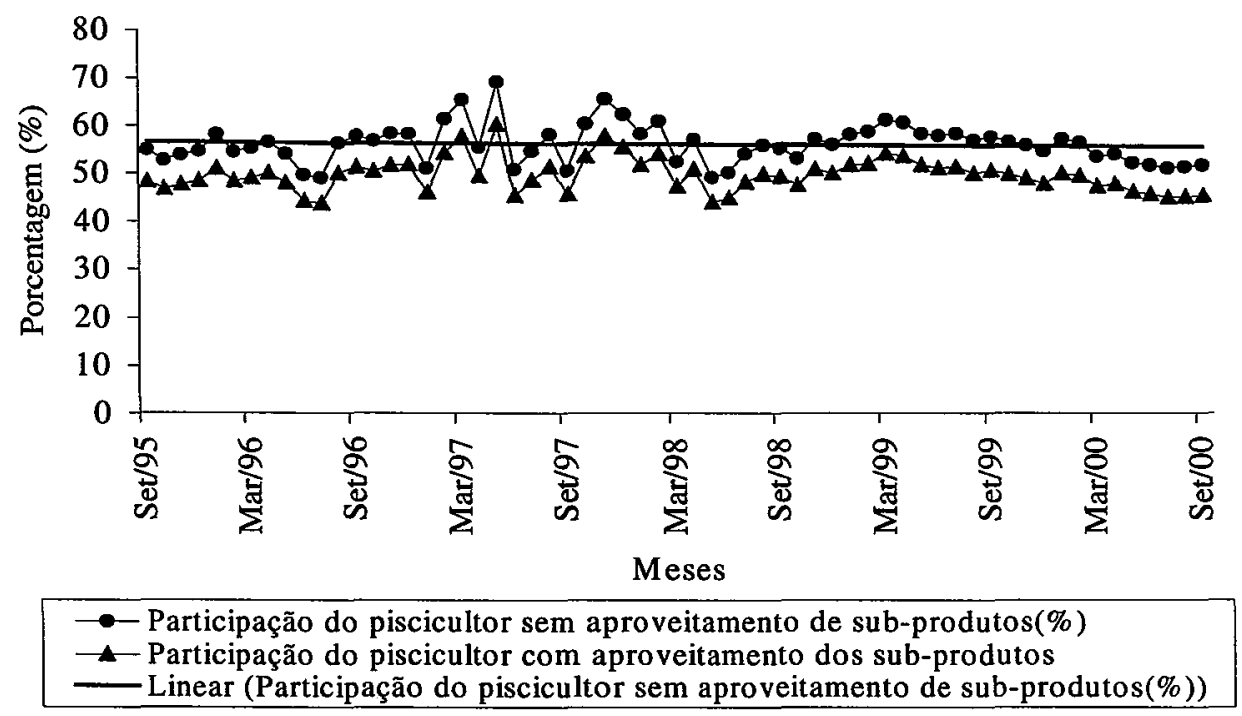

Figura 8 - Evolução da participação do produtor no preço de atacado do filé de tilápia, com aproveitamento dos subprodutos e sem aproveitamento dos subprodutos, no período de setembro de 1995 a setembro de 2000.

Em média, a participação do produtor no preço de venda do filé na indústria é de $49,07 \%$, se a unidade de beneficiamento aproveitar os resíduos para elaborar sub- 
produtos tais como a farinha de peixe, e é de $56,07 \%$, quando a carcaça e a pele do peixe são descartados pela indústria.

É importante ressaltar que o sistema de "quase-integração"12 utilizado pela indústria avícola tem se mostrado eficiente contribuindo para aumentar a competitividade do frango no mercado de carnes, enquanto que para o caso da indústria de beneficiamento de pescado os sistemas de comercialização ainda devem ser aperfeiçoados para que os recursos possam ser melhor distribuídos.

\subsubsection{Evolução da produção e da produtividade}

Analisando a Figura 9 e a Tabela 27, observa-se que a produção física da indústria paranaense de beneficiamento de tilápias cresceu no período entre 1995 e 2000.

Em 1995, a produção industrial foi de 175,71 toneladas de filé de tilápia produzidas por três empresas instaladas na região Oeste do estado, dentre as quais duas possuíam o Serviço de Inspeção Estadual (SIP) e uma possuía apenas o Serviço de Inspeção Municipal (SIM).

No ano de 1996, ocorreu uma redução na quantidade produzida de filé de, aproximadamente, $21,6 \%$ em relação ao ano de 1995 em decorrência da saída de uma empresa que, em 1995, respondeu por aproximadamente $25,04 \%$ da produção.

Contudo, em 1997, o aumento de 48,2\% na produção da empresa líder, aliado à entrada de quatro novas empresas no mercado fez com que a produção industrial de filé de tilápia crescesse em torno de $131,57 \%$ em relação ao ano anterior. A produção de 318,99 toneladas de filé foi realizada por duas empresas com SIP e uma empresa com SIM instaladas na região Oeste do Estado e por duas empresas com SIP e uma com SIM instaladas na região Sudoeste do Paraná (Tabela 27).

\footnotetext{
12 O termo formas intermediárias contratuais rigidas ou quase integração foi formulado por Monteverde \& Teece (1982) identificado como a propriedade de uma firma sobre os equipamentos ou insumos específicos operados por outra firma pertencente a segmentos que lhe são correlatos.
} 


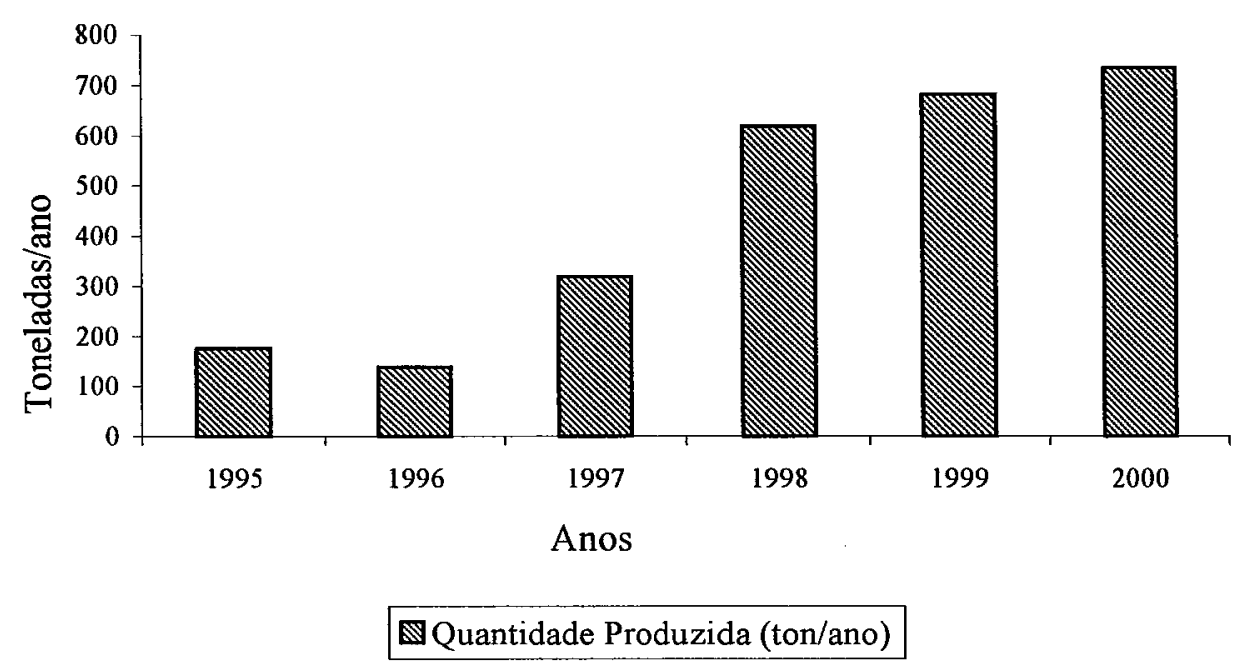

Figura 9 - Evolução da produção industrial de filé da tilápia no Estado do Paraná no período de 1995 a 2000.

Esta tendência manteve-se para o ano de 1998, quando a produção cresceu 93,74\% em relação a 1997 atingindo aproximadamente 618 toneladas de filé de tilápias produzidas por dezesseis empresas, dentre as quais oito possuíam SIP e oito possuíam SIM, sendo que três delas estavam situadas na região Oeste, dez na região Sudoeste, uma na região Noroeste e duas na região Norte do Estado (Tabela 27).

No ano 1999, a produção continuou a crescer, tanto pelo aumento da produção das empresas já instaladas, quanto pela entrada de duas novas empresas com SIP no mercado, situadas também na região Oeste do Paraná.

A partir do ano 2000, entraram no mercado duas empresas com Serviço de Inspeção Federal. Além disso, uma das empresas já instaladas também adequou-se ao SIF. Desta forma, observa-se uma grande modificação nesta indústria que, até 1999, contava com 18 empresas que estavam autorizadas pelos serviços de vigilância sanitária estadual e municipais a operar apenas nos mercados estadual e locais, respectivamente. Observa-se que toda a produção elaborada durante o ano 2000 pelas empresas com SIF 
foi comercializada no mercado estadual. Contudo, a partir de então, o mercado geograficamente restrito deixou de ser um fator limitante do crescimento da produção para estas empresas.

Tabela 27. Evolução da produção industrial de filé de tilápia no período de 1995-2000.

\begin{tabular}{lccc}
\hline Ano & Número de firmas & Quantidade Produzida (ton/ano) & Variação (\%) \\
\hline 1995 & 3 & 175,71 & \\
1996 & 2 & 137,75 & $-21,6$ \\
1997 & 6 & 318,99 & $131,57 \%$ \\
1998 & 16 & 618,0 & $93,74 \%$ \\
1999 & 18 & 681,87 & $10,34 \%$ \\
2000 & 20 & 734,17 & $7,67 \%$
\end{tabular}

Fonte: Dados da pesquisa

Outro fator importante em relação ao desempenho da indústria paranaense de beneficiamento de pescado diz respeito à sua elevada capacidade ociosa, que foi, em média, de $87,42 \%$ no período estudado, apesar de variar bastante entre as empresas, especialmente, em função do seu tamanho, conforme pode ser visto na Tabela 28.

De acordo com as empresas entrevistadas, os motivos que explicam a alta ociosidade são os problemas enfrentados no mercado de peixe vivo bem como as dificuldades na hora da comercialização junto ao distribuidores varejistas. Neste caso, também é importante destacar que a existência e a manutenção dos estabelecimentos clandestinos concorrendo de forma desleal é outro fator que pode estar contribuindo para aumentar a capacidade ociosa na indústria de beneficiamento de tilápias porque concorrem com as unidades de beneficiamento tanto no mercado de matéria-prima quanto no mercado de filé. 
Tabela 28. Porcentagem de capacidade ociosa média para indústria no período de 1995 a 2000.

\begin{tabular}{|c|c|c|c|c|}
\hline Ano & $\begin{array}{l}\text { Empresas com } \\
\text { SIF }\end{array}$ & Empresas com SIP & $\begin{array}{l}\text { Empresas com } \\
\text { SIM }\end{array}$ & Média da Indústria \\
\hline 1995 & - & 89,05 & 98,20 & $89,23 \%$ \\
\hline 1996 & - & 82,83 & 98,20 & $85,0 \%$ \\
\hline 1997 & - & 89,36 & 98,34 & $89,83 \%$ \\
\hline 1998 & - & 85,12 & 96,84 & $86,58 \%$ \\
\hline 1999 & - & 85,17 & 96,84 & $86,50 \%$ \\
\hline 2000 & 87,74 & 85,32 & 96,84 & $87,39 \%$ \\
\hline
\end{tabular}

Fonte: Calculado a partir de dados da pesquisa.

Procurou-se também calcular a produtividade do trabalho na indústria de beneficiamento de tilápia do Paraná, para os anos de 1999 e 2000, e tomando-se como proxy da produtividade a razão produção/horas homem trabalhadas. Os valores obtidos são mostrados na Tabela 29.

Para obter o número de horas/homem/ano trabalhadas na elaboração de filé, considerou-se o número de trabalhadores responsáveis pelo abate e filetagem vezes a carga horária de trabalho mensal vezes o número de meses que a empresa esteve em funcionamento no respectivo ano.

É importante salientar que, de acordo com os questionários, o número de empregados fixos tem se mantido constante na maioria das empresas desde 1998. Além disso, a produção de algumas empresas, principalmente das pequenas empresas que operam nos mercados locais, também manteve-se constante no ano 2000. Isso se deve ao tamanho restrito do seu mercado e também às baixas temperaturas ocorridas no ano 2000 que restringiram a produção de matéria-prima, limitando a produção de filé, especialmente das empresas que utilizam exclusivamente matéria-prima própria.

Verifica-se que a produtividade do trabalho na produção de filé varia muito na indústria estudada. Observa-se, por exemplo, uma significativa diferença entre a produtividade média das empresas com SIF e das empresas com SIP e SIM. Esta diferença pode ser explicada pela capacidade ociosa de cada empresa e pelos diferentes 
níveis de divisão do trabalho adotados em cada uma delas. Enquanto as empresas com Inspeção Sanitária Municipal operam apenas algumas horas por semana empregando, em média, três trabalhadores e utilizando matéria-prima própria, as empresas com Inspeção Sanitária Estadual e Federal empregam, em média, oito e dezesseis funcionários, respectivamente, na linha de produção e trabalham entre três e cinco dias da semana.

Tabela 29. Razão produção/empregado nos anos de 1999 e 2000.

\begin{tabular}{|c|c|c|c|c|c|c|c|c|c|c|}
\hline & \multicolumn{2}{|c|}{$\begin{array}{l}\text { Número de } \\
\text { Empresas }\end{array}$} & \multicolumn{2}{|c|}{$\begin{array}{c}\text { Número Total de } \\
\text { Empregados }\end{array}$} & \multicolumn{2}{|c|}{$\begin{array}{c}\text { Horas/homem/ano } \\
\text { trabalhadas }\end{array}$} & \multicolumn{2}{|c|}{$\begin{array}{l}\text { Quantidade } \\
\text { Produzida } \\
\text { (ton/ano) }\end{array}$} & \multicolumn{2}{|c|}{$\begin{array}{c}\text { Produtividade Média } \\
\text { Anual }\end{array}$} \\
\hline & 1999 & 2000 & 1999 & 2000 & 1999 & 2000 & 1999 & 2000 & 1999 & 2000 \\
\hline $\begin{array}{l}\text { Empresas } \\
\text { com SIF }\end{array}$ & - & 03 & - & 48 & - & 52.704 & - & 258.411 & - & 5,60 \\
\hline $\begin{array}{l}\text { Empresas } \\
\text { com SIP }\end{array}$ & 10 & 09 & 89 & 69 & 144.064 & 101.824 & 664.473 & 458.360 & 3,85 & 3,37 \\
\hline $\begin{array}{l}\text { Empresas } \\
\text { com SIM }\end{array}$ & 08 & 08 & 24 & 24 & 18.432 & 18.432 & 17.400 & 17.400 & 0,94 & 0,94 \\
\hline Produtivid & de Méd & a da In & dústria & & & & & & 2,56 & 2,90 \\
\hline
\end{tabular}

Fonte: Dados da pesquisa.

Nota-se que a produtividade média na indústria como um todo cresceu no ano 2000 se comparada ao ano anterior (ver Tabela 29).

Em síntese, é possível concluir que o desempenho insatisfatório da indústria de beneficiamento de tilápia no Estado do Paraná decorre das condições básicas de oferta e demanda, da estrutura e da conduta das empresas.

A estrutura atomizada e pouco concentrada deste mercado, em que um grande número de empresas agem de forma independente e pouco organizada produzindo em baixa escala, com altos custos e preços finais pouco competitivos em relação os produtos substitutos aliada à conduta pouco agressiva da referida indústria que, praticamente, não 
adota estratégias competitivas nem estabelece acordos e contratos ficando em condição vulnerável em relação aos fornecedores, distribuidores e concorrentes explicam a tendência de queda nos preços e nas margens absolutas de comercialização do filé de tilápia, a baixa produtividade e a elevada capacidade ociosa que comprometendo o desempenho e a competitividade do complexo piscícola estadual. 


\title{
6 CONCLUSÕES
}

\begin{abstract}
O objetivo deste trabalho foi estudar a organização da indústria de beneficiamento de tilápias-do-nilo criadas em cativeiro no Estado do Paraná, destacando-se aspectos de sua estrutura, conduta e desempenho. Entende-se como indústria de beneficiamento de pescado cultivado o conjunto de empresas que utilizam peixes cultivados em água doce, neste caso tilápia-do-nilo, como matéria-prima para elaboração de produtos e derivados de peixe.

Para a realização deste trabalho foi utilizada a abordagem teórica da Organização Industrial: o paradigma estrutura-conduta-desempenho. Os dados utilizados foram obtidos via entrevista face a face e via telefone junto aos proprietários ou administradores de todas as unidades de beneficiamento de tilápia, proveniente da aqüicultura, situadas no Paraná, e que, em 2000, estavam autorizadas, pelo Serviço de Inspeção Sanitária e Industrial do seu município ou do Estado do Paraná ou do Ministério da Agricultura, a beneficiar e comercializar pescados e derivados no mercado paranaense.

Apesar das condições ambientais, climáticas e estruturais que caracterizam todas as grandes regiões brasileiras como potenciais para prática aquícola, a região Sul do Brasil é a responsável pela maior produção de pescado cultivado no país, que tem como maiores produtores os estados do Paraná e de Santa Catarina. Enquanto em Santa Catarina são produzidos mexilhões, ostras, camarão e peixes, no estado do Paraná a aqüicultura está orientada para o cultivo de várias espécies de peixes, especialmente tilápias-do-nilo.
\end{abstract}


No Paraná, especialmente na região Oeste do Estado, vários fatores contribuíram para o surgimento da piscicultura, entre eles, podem ser citados os programas de manejo e conservação de solos e os programas de preservação de matas ciliares implementados pelo Governo do Estado, que permitiram melhorar a qualidade dos recursos hídricos além da necessidade de diversificar as atividades rurais como forma de complementar a renda dos pequenos produtores, até então acostumados à prática das monoculturas da soja, do milho e do trigo. Ainda, teve importante papel no desenvolvimento da piscicultura paranaense, o Programa de Pesca e Aqüicultura desenvolvido pela Secretaria de Estado da Agricultura e do Abastecimento que concedia subsídios, em horas/máquinas, para construção de viveiros.

Ainda no início da década de 90 , a piscicultura já se destacava como atividade alternativa nas pequenas propriedades rurais, permitindo que surgissem novas empresas dos mais diversos segmentos da cadeia produtiva, que vieram disponibilizar ao setor produtivo novas tecnologias nas áreas de nutrição, genética e manejo. Tanto a produção de ração para peixe e de equipamentos (aeradores e comedouros automáticos) quanto a técnica de reversão sexual de tilápias vieram viabilizar aumentos significativos da produtividade bem como a produção peixe em larga escala ao longo do ano, condição necessária para o surgimento e funcionamento da indústria.

A indústria de beneficiamento surge no Paraná ainda na primeira metade da década de 90, com o intuito de organizar a produção e a distribuição do peixe produzido, uma vez que até então o piscicultor era penalizado com o mercado sazonal para o peixe, geralmente, restrito ao período da quaresma.

É importante destacar que, no Oeste paranaense, as técnicas de produção introduzidas e as soluções encontradas para os problemas do setor, encaminharam a atividade, desde o seu princípio, para a industrialização, enquanto, nas outras regiões do Estado, a piscicultura desenvolveu-se com o intuito de aproveitar a oportunidade de mercado representada pelo crescente número de pesque-pagues instalados no Paraná, em São Paulo e Minas Gerais. Prova disso, é o fato da região Oeste ser a maior produtora e também a região que mais comercializa junto a indústria, inclusive depois da consolidação dos pesque-pagues. 
Isto leva a crer que as unidades de beneficiamento tiveram e continuam tendo um importante papel no desenvolvimento da piscicultura paranaense. Este fato aliado à inexistência de outros trabalhos sobre a organização da referida indústria despertaram o interesse pela realização do presente estudo.

Quanto aos aspectos da estrutura da indústria paranaense de beneficiamento de tilápias cultivadas, constatou-se que apresenta uma baixa concentração, com presença de muitas empresas produtoras, muitos compradores e algumas barreiras à entrada de novas empresas, podendo ser classificada, segundo Carlton \& Perloff (1991), como competição monopolística. No entanto, ao analisar os indicadores calculados para as diferentes regiões do Estado percebe-se que os valores das razões de concentração variam de uma região para outra, indicando que os valores encontrados para o Paraná como um todo subestimam o poder de mercado eventualmente exercido por algumas empresas em mercado regionais.

Ainda, constatou-se que as principais e mais fortes barreiras à entrada de novas empresas na indústria são o acesso à matéria-prima, o custo do capital de giro, o investimento necessário à implantação do projeto e dificuldade na comercialização. No entanto, observa-se que a escassez de matéria-prima $e$ as dificuldades na comercialização apontadas como fortes barreiras à entrada de novas empresas são problemas decorrentes da estrutura de governança adotada pelas empresas que realizam transações com fornecedores e distribuidores através do mercado. Desta forma, é possível concluir que tanto a ação isolada e independente das empresas quanto a ausência de contratos entre unidades de beneficiamento e fornecedores de matéria-prima comprometem o desempenho eficiente da indústria já estabelecida, e o seu desempenho ineficiente acaba facilitando a entrada de empresas oportunistas e pouco profissionais tanto no mercado formal quanto informal.

Constata-se também que a informalidade é o resultado da um conjunto de elementos institucionais e competitivos, tais como a alta sensibilidade do consumo em relação aos preços, a existência de produtos substitutos e a pouca exigência em relação à qualidade e segurança sanitária do pescado por parte dos consumidores. Além disso, a fiscalização é insuficiente e, geralmente, voltada para os estabelecimentos legalizados. 
Este fator confere vantagens aos produtores que operam no mercado clandestino. A concorrência desleal existente entre os estabelecimentos clandestinos e legalizados certamente tem contribuído para aumentar a capacidade ociosa dos últimos, uma vez que competem tanto no mercado de peixe vivo quanto no mercado de filé.

A conduta da indústria de beneficiamento de pescado cultivado em água doce, com relação à formação de preços é condizente com sua estrutura atomizada e pouco concentrada, que dificulta as práticas de fixação de preços. Ou seja, apesar de existirem algumas firmas que lideram o mercado e que tentam ditar preços enquanto outras apenas tomam preços no mercado, observa-se que a conduta predominante é a negociação de preço entre a indústria e os distribuidores. Ainda, com relação aos preços, constatou-se que a maioria das empresas com SIF e SIP reduzem suas margens de lucros para manter o preço nominal do produto. Este comportamento também decorre da estrutura de mercado que caracteriza a referida indústria, uma vez que as empresas concorrem entre si competindo principalmente via preço e que os consumidores de filé são bastante sensíveis ao preço do produto.

As estratégias de competição extra-preço adotadas pelas firmas frente à concorrência são bastante tímidas. A competição extra-preço, via diferenciação e ou diversificação dos produtos, praticamente não ocorre. $O$ principal diferencial diz respeito às formas de congelamento e embalagem. Além disso, os gastos com propaganda, promoções de vendas e medidas de controle de qualidade do produto são esporádicos. Esta conduta decorre da falta de capital e da ausência de rivalidade entre as empresas.

Com relação às estratégias de venda, observou-se que todas as empresas realizam suas vendas mediante encomenda por telefone ou então por meio de pedidos nas ocasiões em que são feitas as entregas dos pedidos anteriores e, as empresas que atuam no mercado estadual e federal, também, utilizam-se de televendas, de serviços terceirizados e pronta entrega. $O$ fato das empresas que atendem a mercados mais amplos utilizarem diversas formas de comercialização para fazer seu produto chegar ao consumidor final reflete uma certa dificuldade na comercialização. Esta conduta condiz com situações em que existem muitas empresas, com baixo poder de mercado, disputando o consumidor. 
Conclui-se que existe uma relação de reciprocidade entre as condições básicas de oferta e de demanda, a estrutura atomizada e pouco concentrada e a conduta pouco agressiva da referida indústria. A ação isolada e desorganizada das empresas, a baixa capacidade de auto financiamento, a ausência de acordos e contratos que visem coordenar a produção e a falta de estratégias competitivas resultam em escassez de matéria-prima, vulnerabilidade das empresas junto aos fornecedores, distribuidores e concorrentes (pesque-pagues) que, por sua vez, comprometem o desempenho do setor.

Em relação ao desempenho da referida indústria, notou-se que os preços reais do filé de tilápia apresentaram um comportamento relativamente estável, com exceção do ano de 1997, com uma leve tendência de declínio no período analisado. As oscilações ocorridas nos preços reais do filé de tilápia, se explicam, principalmente, pelo aumento do número de unidades de beneficiamento de tilápias em todo o Estado, seguido do aumento da quantidade ofertada de filé no mercado estadual.

Ainda com relação às margens de comercialização, observou-se uma tendência de queda nas margens absolutas de comercialização do atacadista, tanto no caso em que são aproveitados quanto no caso em que são descartados os subprodutos. Isto se deve ao aumento da oferta de filé de tilápia, em todo o Estado do Paraná, à forte concorrência dos pesque-pagues no mercado de peixe vivo, que tem obrigado as unidades de beneficiamento a manter os preços reais pagos aos piscicultores como também à entrada de novas empresas no mercado, que têm ampliado o poder de negociação dos varejistas. Além disso, a sensibilidade do consumo de filé em relação ao preço do produto e à renda e a existência de produtos concorrentes, como o frango, também explicam a redução das margens de comercialização da indústria. Todos esses fatores, também explicam porque a grande maioria das empresas afirmou que reduzem suas margens de lucro para manter o preço.

Outro importante indicador de desempenho desta indústria é a participação relativa dos produtores no preço de venda do filé de tilápia na indústria que tem sido elevada ao longo do período, apresentando uma tendência estável, tanto quando a empresa comercializa os subprodutos bem como quando os descarta. Essa elevada 
participação dos piscicultores no preço do filé praticado pela indústria se deve, sobretudo, ao fato do filé de tilápia ser um produto pouco elaborado.

Ao considerar a produtividade física por trabalhador, para os anos de $1998 \mathrm{e}$ 2000 , constatou-se que tem aumentado, embora varie muito de uma empresa para outra, em função das diferentes escalas de produção, da capacidade ociosa e dos diferentes graus de divisão do trabalho adotados em cada uma delas. Constata-se, por exemplo, que nas empresas com SIM, apesar de possuírem uma capacidade instalada pequena, produzem pequenas quantidades de filé trabalhando, aproximadamente, oito dias por mês, empregando, em média, três funcionários que realizam todas as tarefas desde o abate até a embalagem do produto, em geral, a produtividade é muito menor do que nas empresas com SIP e SIF, nas quais existe maior especialização da mão-de-obra, maior escala e menor capacidade ociosa.

Conclui-se que o desempenho da indústria de beneficiamento de tilápia no Estado do Paraná reflete o baixo poder de mercado das empresas e a ausência de rivalidade entre as empresas.

A estrutura atomizada e pouco concentrada deste mercado - caracterizado por um grande número de empresas agem de forma independente e pouco organizada aliada à conduta pouco agressiva das empresas que, praticamente, não adotam estratégias competitivas nem estabelecem acordos e contratos, ficando em condição vulnerável em relação aos fornecedores, distribuidores e concorrentes bem como a sensibilidade dos consumidores em relação ao preço do produto e a existência de produtos substitutos explicam a tendência de queda nos preços e nas margens absolutas de comercialização do filé de tilápia, a baixa produtividade e a elevada capacidade ociosa que comprometem não apenas a sustentabilidade da indústria de beneficiamento como também dos demais setores da cadeia produtiva.

Este trabalho também mostra que ainda existem mercados importantes a serem explorados pela indústria de beneficiamento de pescado dentro do território estadual, tais como o mercado de refeições industriais e da merenda escolar. No entanto, percebe-se a necessidade de estratégias de desenvolvimento de curto e longo prazo para o setor piscícola. 
Ao finalizar este estudo é possível afirmar que cabe à indústria coordenar a produção piscícola no Estado, não somente pelas dificuldades que tem enfrentado como também pelo papel estratégico que possui no complexo piscícola paranaense. É fundamental que as empresas se associem para discutir e buscar soluções que visem resolver não somente os seus problemas como também aqueles que atingem a toda a cadeia produtiva da piscicultura e que comprometem sua competitividade, tais como:

a) viabilizar a produção de insumos de maior qualidade, em maior quantidade $\mathrm{e}$ menores preços. Sabe-se que os elevados custos de produção decorrentes da baixa qualidade e do alto preço da ração tem obrigado os produtores a vender o peixe aos pesque-pagues que pagam preços maiores do que a indústria;

b) viabilizar o aproveitamento dos resíduos de pescado resultantes do abate para a fabricação de farinha de peixe e artefatos de pele de tilápia resolvendo um problema ambiental e melhorando o desempenho da indústria;

c) viabilizar a cooperação entre produtores e indústria como forma de assegurar a oferta e a qualidade da matéria-prima utilizada, possibilitando a especialização do produtor em alevinagem, produção de alevinos juvenis, e a engorda propriamente dita, e conferindo à indústria maior poder de mercado diante de fornecedores, distribuidores (varejistas) e concorrentes (especialmente aqueles que operam no mercado informal);

d) estimular a criação de canais de distribuição especializados com amplitude geográfica que possibilitem a redução de custos logísticos;

e) realizar campanhas de marketing conjunto para divulgar o produto reduzindo o custo por empresa uma vez que estas, em geral, não possuem capital financeiro para fazer campanhas individuais.

Acredita-se que a adoção das medidas acima sugeridas seria o primeiro passo a ser dado pela indústria de beneficiamento de tilápia no sentido de reduzir capacidade ociosa e os seus custos, expandindo seu mercado.

É importante destacar que alguns pontos deste trabalho podem ser melhorados a partir de novas pesquisas, pois dadas as dificuldades no levantamento primários das informações, o tempo necessário è o alto custo, não foi possível aprofundar. Ao concluir 
este trabalho, considera-se prioritário realizar pesquisas sobre o mercado informal, sobre o mercado de insumos e sobre o setor de distribuição de filé de tilápia.

Observou-se através deste trabalho uma grande participação da produção informal neste mercado. Considera-se de extrema importância estudar os fatores institucionais e organizacionais que condicionam o seu surgimento e expansão. $O$ setor de distribuição de filé também precisa ser mais profundamente estudado para que se possa avaliar o seu desempenho bem como os seus reflexos sobre a cadeia produtiva. Sabe-se que os elevados custos de produção, especialmente da ração para peixe, têm refletido na indústria de beneficiamento e, conseqüentemente, no mercado consumidor. É imprescindível, portanto, conhecer melhor o setor, identificando os gargalos e apontando possíveis soluções que venham trazer benefícios a toda a cadeia produtiva. 


\section{REFERÊNCIAS BIBLIOGRÁFICAS}

ABDALLAH, P.R. Atividade pesqueira no Brasil: política e evolução. Piracicaba, 1998. 137p. Tese (Doutorado) - Escola Superior de Agricultura "Luiz de Queiroz" - Universidade de São Paulo.

AGUIAR, D.R.D. A indústria de esmagamento de soja no Brasil: mudança estrutural, conduta e alguns indicadores de desempenho. Revista de Economia e Sociologia Rural, v.32, n.1, p.23-46, jan/mar. 1994.

BAIN, J.S. Industrial organization. 2. ed. New York: Jhn Wiley, 1968.

BARROS, G.S.C. Economia da comercialização agrícola. Piracicaba: FEALQ, 1987. 306p.

BENITES, C. Situação atual de aqüicultura na Região Centro-oeste. In: VALENTI, W.C.; POLI, C.R.; PEREIRA, J.A.; BORGHETTI, J.R. Aqüicultura no Brasil: bases para um desenvolvimento sustentável. Brasília: CNPq/Ministério da Ciência e Tecnologia, 2000. Cap.9, p.289-301.

CANTO,W.L.(Coord). Sistema ponderal de conversões e determinação de margens de comercialização. Campinas: ITAL, 1986. 58p. (Estudos Econômicos, 22).

CARLTON, B.; PERLOFF, J. Modern industrial organization. Harper Collins, 1991.

CARVALHO, F. C. de; SOARES, M.F.V.; DESGUALDO NETTO, D. Margens de comercialização de pescado em São Paulo. In: CONGRESSO BRASILEIRO DE ECONOMIA E SOCIOLOGIA RURAL, 18., Rio de Janeiro, 1980. Agricultura e Desenvolvimento; resumos. Rio de Janeiro: SOBER, 1980.

CASTAGNOLLI, N. Status of aquaculture in Brazil. World Aquaculture, v.26, n.4, p.35-39, 1995. 
CYRINO, J.E.P; GRŸSCHEK, J.M.B. A piscicultura como agroindústria no Brasil. In: SIMPÓSIO SOBRE MANEJO E NUTRIÇÃO DE PEIXES, 1., Piracicaba, 1997. Anais. Campinas: CNBA, 1997. p.1-30.

EMPRESA DE ASSISTÊNCIA TÉCNICA E EXTENSÃO RURAL DO PARANÁ. Realidade da Piscicultura Paranaense - Safra 1996/1997. Curitiba: EMATER/Paraná, 1997. 1v.

EMPRESA DE ASSISTÊNCIA TÉCNICA E EXTENSÃO RURAL DO PARANÁ. Realidade da Piscicultura Paranaense - Safra 1997/1998. Curitiba: EMATER/Paraná, 1998. 1v.

EMPRESA DE ASSISTÊNCIA TÉCNICA E EXTENSÃO RURAL DO PARANÁ. Realidade da Piscicultura Paranaense - Safra 1998/1999. Curitiba: EMATER/Paraná. 1999. 1.v.

FAO. Fishery statistics: catches and landings. Roma, 1994. (FAO Statistics Series, 44)

FAO. Documentations Group Cataloguing in Publication Data. The State of World Fisheries and Aquaculture. Roma, 1998. 98p.

FAO. Fish Estatistic.Plus (compact disc - versão 2.30). Roma, 2000.

FERGUSON, C.E. Teoria microeconômica. Rio de Janeiro: Forense Universitária, 1992. 624p.

GIULIETTI, N. (Coord.). Cadeia produtiva do pescado. São Paulo: SEAB, 1996. 57p./No prelo/.

GIULIETTI, N.; ASSUMPÇÃO, R. Indústria pesqueira no Brasil. Agricultura em São Paulo, v.42, n.2, p.95-127, 1995.

GRUPO DE ESTUDOS E PESQUISAS EM AGRONEGÓCIOS-GEPEC. Planilhas de custos da piscicultura. Toledo: UNIOESTE, abril/2001. (Relatório)

GUIMARÃES, E.A. Acumulação e crescimento da firma: um estudo de organização industrial. Rio de Janeiro: Zahar, 1981.

HOFFMAN, H. Elasticidades-renda das despesas com alimentos em regiões metropolitanas do brasil em 1995-96. Informações Econômicas, v.30, n.2, p.1724 , fev. 2000.

HOPKINS, T.A.; NANCI, W.E. Aquaculture: Oportunity Now. Aquaculture Magazine, v.19, n.1, p.30-38, jan/fev, 1993. 
$\mathrm{KOCH}$, J.V. Industrial organization and prices. 2. ed. New Jersey: Englewood Cliffs, 1980. p.504.

LEISMANN, E.L.; AGUIAR, D.R.D. Poder de mercado e preços pagos aos produtores na indústria de esmagamento de soja no Brasil (compact disc). In: CONGRESSO BRASILEIRO DE ECONOMIA E SOCIOLOGIA RURAL, 39. Recife, 2001. Competitividade e globalização: impactos regionais e locais. Brasília: Sociedade Brasileira de Economia e Sociologia Rural, 2001. 1v.

LIBARDI, D; PHILIPPI, L.; CASACA, J.M. Estudo de viabilidade técnicaeconômica da implantação de projeto de aqüicultura pela Copacol. Curitiba: Vet-Maxi Maximização Pecuária, 1996. 96p.

MARANHÃO, T.C.F. Processamento e comercialização de pescado produzido em cativeiro: tilápias. In: SIMPÓSIO SOBRE MANEJO E NUTRIÇÃO DE PEIXES, 2., Piracicaba, 1998. Anais. Campinas: CBNA, 1998.

MARQUES,P.V.; AGUIAR, D.R.D.de. Comercialização de produtos agrícolas. São Paulo: Edusp, 1993. 296p.

MARTIN, R.V. Levantamento da cadeia produtiva do pescado do reservatório de Itaipu. Toledo, 1998. 84p. Monografia (Graduação) - Universidade Estadual do Oeste do Paraná.

MARTINS, C.V.B.; OLIVEIRA, D.P.; MARTINS, R.S. ; HERMES, C.A.; OLIVEIRA, L.G.; VAZ, S.O.; MINOZZO, M.; CUNHA, M; ZACARKIN, C.E. Política pública na piscicultura: o caso da região oeste do Estado do Paraná (compact disc). In: SIMPÓSIO BRASILEIRO DE AQÜICULTURASIMBRAq, 11., Florianópolis, 2000. São Paulo: Associação Brasileira de Aqüicultura, 2000.1v.

MEDEIROS, N.H.; REIS, S.V. A concentração industrial na cadeia alimentar da soja (compact disc). In: CONGRESSO BRASILEIRO DE ECONOMIA E SOCIOLOGIA RURAL, 37., Foz do Iguaçu, 1999. Brasília: Sociedade Brasileira de Economia e Sociologia Rural, 1999. 1v.

MORAES, M.A.F.D. A indústria de madeira preservada no Brasil: um estudo de sua organização industrial. Piracicaba, 1996. 154p. Dissertação (Mestrado) - Escola Superior de Agricultura "Luiz de Queiroz", Universidade de São Paulo.

MORIMOTO, P.T. Demanda de pescado no mercado da grande São Paulo. Viçosa, 1975. 40p. Dissertação (Mestrado) - Universidade Federal de Viçosa.

NEIVA, G.S. Subsídios para a política pesqueira nacional. Santos: Terminal Pesqueiro, 1990. 
OLIVEIRA, E.R.; BORGES JUNIOR, A. O oligopsônio do leite no Brasil (compact disc). In: CONGRESSO BRASILEIRO DE ECONOMIA E SOCIOLOGIA RURAL, 37., Foz do Iguaçu, 1999. Brasília: Sociedade Brasileira de Economia e Sociologia Rural, 1999. 1v.

OKAWA, H. Análise harmômica das variações dos preços e das quantidades de sardinha fresca no mercado atacadista de São Paulo: 1981/82. Piracicaba, 1985. 96p. Dissertação (Mestrado) - Escola Superior de Agricultura "Luiz de Queiroz", Universidade de São Paulo.

OSTRENSKY, A; BORGHETTI, J.R.; PEDINI, M. Situação atual da aqüicultura brasileira e mundial. In: VALENTI, W.C.; POLI, C.R.; PEREIRA, J.A.; BORGHETTI, J.R. Aqüicultura no Brasil: bases para um desenvolvimento sustentável. Brasília: CNPq/Ministério da Ciência e Tecnologia, 2000. Cap.12, p.353-381.

PARANÁ. Secretaria do Estado do Meio Ambiente e dos Recursos Hídricos. Superintendência de Desenvolvimento de Recursos Hídricos e Saneamento Ambiental. Portaria n 20, de 30 de abril de 1996. Curitiba: SUDERHSA, 1996.

PARANÁ. Secretaria do Estado da Fazenda. Decreto n ${ }^{\circ} 4.621$, de 27 de julho de 1998. Curitiba: SEFA, 1998.

PARANÁ. Secretaria do Estado da Agricultura e do Abastecimento. Serviço de Inspeção do Paraná: produtos de origem animal. Regulamento de inspeção sanitária e industrial para produtos de origem animal: geral. Curitiba: DEFIS, 1999(a).

PARANÁ. Secretaria do Estado da Agricultura e do Abastecimento. Serviço de Inspeção do Paraná: produtos de origem animal. Regulamento de inspeção sanitária e industrial para produtos de origem animal: pescados. Curitiba: DEFIS, 1999(b).

PARIZOTO, M.L. Um estudo sobre o mercado produtor de alevinos no Oeste do Paraná. Toledo. 1999. 80p. Monografia (Especialização) - Universidade Estadual do Oeste do Paraná.

PEREIRA, M J.A.; SILVA, A.L.N.; CORREIA, E.S. Situação atual da aqüicultura na região Nordeste. In: VALENTI, W.C.; POLI, C.R.; PEREIRA, J.A.; BORGHETTI, J.R. Aquiicultura no Brasil: bases para um desenvolvimento sustentável. Brasília: CNPq/Ministério da Ciência e Tecnologia, 2000. Cap.8, p.267-288. 
PEZZATO, L.E.; SCORVO FILHO, J.D. Situação atual da aqüicultura na região Sudeste. In: VALENTI, W.C.; POLI, C.R.; PEREIRA, J.A.; BORGHETTI, J.R. Aquiicultura no Brasil: bases para um desenvolvimento sustentável. Brasília: CNPq/Ministério da Ciência e Tecnologia, 2000. Cap.10, p.303-322.

POLI, C.R.; GRUMANN, A.; BORGHETTI, J.R. Situação atual da aqüicultura na região Sul. In: VALENTI, W.C.; POLI, C.R.; PEREIRA, J.A.; BORGHETTI, J.R. Aqüicultura no Brasil: bases para um desenvolvimento sustentável. Brasília: CNPq/Ministério da Ciência e Tecnologia, 2000. Cap.11, p.323-351.

PROENÇA, C.E.M.; OLIVEIRA NETO, F.M. Legislação. In: VALENTI, W.C.; POLI, C.R.; PEREIRA, J.A.; BORGHETTI, J.R. Aqüicultura no Brasil: bases para um desenvolvimento sustentável. Brasília: CNPq/Ministério da Ciência e Tecnologia, 2000. Cap.4, p.143-179.

RISSATO, D. Diagnóstico econômico da atividade piscícola ao nível de produtor associado à Associação de Aqüicultores do Oeste do Paraná - AQUIOPAR. In: ENCONTRO SUL BRASILEIRO DE AQUICULTURA, 3.; ENCONTRO RIOGRANDENSE DE TÉCNICOS EM AQUICULTURA, 6., Ibirubá, 1995. Anais. Ibirubá: Universidade Federal do Rio Grande do Sul, Depto. de Zootecnia, Setor de Aquicultura, 1995.

RISSATO, D; MOREIRA, E.A.; PAULERT, T.F. Estratégias de marketing para a expansão do mercado de filé de peixe - tipo tilápia-do-nilo. Curitiba, 1996. 43p. Monografia (Especialização) - Universidade Federal do Paraná.

RISSATO, D; MARQUES, P.V. Estrutura, conduta e desempenho das unidades de beneficiamento de pescado produzido em cativeiro no Estado do Paraná (compact disc). In: CONGRESSO BRASILEIRO DE ECONOMIA E SOCIOLOGIA RURAL, 37., Foz do Iguaçu, 1999. Brasília: Sociedade Brasileira de Economia e Sociologia Rural, 1999. 1v.

RISSATO, D. Análise da agroindústria piscícola paranaense sob a ótica da economia dos custos de transação. In: CONGRESSO BRASILEIRO DE ECONOMIA E SOCIOLOGIA RURAL, 39., Recife, 2001. Anais. Brasília: Sociedade Brasileira de Economia e Sociologia Rural, 2001. 1v.

ROLIM, P.R. A infra-estrutura básica para a criação de peixesno Amazonas, In: VAL, A.L.; HONCZARYK, A. (Ed). Criando peixes na Amazônia. Manaus: INPA, 1995. p.7-16.

SCHERER, F.M. Industrial market structure and economic performance. Chicago: Rand Mc Nally College Publishing, 1970.

SCHERER, F.M. Preços industriais: teoria e evidência. Rio de Janeiro: Campus, 1979. 242p. 
SCHERER, F.M.; ROSS, d. Industrial market structure and economic performance. 3. ed. Boston: Houghton Mifflin Company, 1990.

SHANG, Y.C. Aqualculture economic analysis: an introduction. Honolulu: The World Aquaculture Society, 1990. Cap.11, p.133-140: Marketing Infrastructures and Systems.

SUGAI M.; MUEHLMANN, L.D.; YOKOYAMA, W.H. Piscicultura. Curitiba: /1998?/. 10p.

TAKASHIMA, F.; STRUSSMANN, C.A. Aquaculture in Japan tecent trends. In: INTERNATIONAL SEMINAR ON FISHERIES IN TROPICAL AREA, 2., Tóquio: s.ed., 1997. p.87-91.

VAL, A.L.; ROLIM, P.R.; RABELO, H. Situação atual da aqüicultura na região Norte. In: VALENTI, W.C.; POLI, C.R.; PEREIRA, J.A.; BORGHETTI, J.R. Aquiicultura no Brasil: bases para um desenvolvimento sustentável. Brasília: CNPq/Ministério da Ciência e Tecnologia, 2000. Cap.7, p.247-266.

VALLE, R.P.; PROENÇA, C.E.M. Evolução e perspectivas da aqüicultura no Brasil. In: VALENTI, W.C.; POLI, C.R.; PEREIRA, J.A.; BORGHETTI, J.R. Aqüicultura no Brasil: bases para um desenvolvimento sustentável. Brasília: CNPq/Ministério da Ciência e Tecnologia, 2000. Cap.13, p.383-398. 
APÊNDICE 


\section{Questionário para levantamento das agroindústrias do Paraná}

Nome:

Endereço:

Cidade:

CEP:

Fax:

E-mail:

Fone:

Data em que começou a operar no mercado?

A partir de quando a empresa obteve o SIF (mês/ano):

Tempo médio de estocagem do filé na empresa?

(_ ( ) filé resfriado

(_) filé congelado

A empresa faz o aproveitamento dos sub-produtos:

PELE

(_) descartada (_) destina-se a curtumes

( $($ ) destina-se à fábrica de farinha de peixe

\section{CARCACA}

(_) descartada

(_ ) destina à fabricação de farinha de peixe

Em quanto você avalia o capital investido na sua empresa?

Qual o capital de giro mensal necessário para manter em funcionamento a sua empresa?

Tipo de embalagem utilizado para acondicionar o filé que será comercializado:

(_) rolinhos

(_) pacotes

) bandejas

(_) outros

Você considera a oferta de matéria-prima básica (peixe) escassa ou abundante, livre ou cartelizada

\begin{tabular}{|l|l|l|l|l|}
\hline Matéria-prima & Escassa & Cartelizada & Livre & Abudante \\
\hline Peixe vivo & & & & \\
\hline
\end{tabular}

Sua empresa possui produção própria de pescado ou compra de terceiros? Indicar quantos \% do pescado filetado é produzido ou comprado?

\begin{tabular}{|l|l|l|}
\hline & $\%$ de produção própria & \% produção comprada \\
\hline Peixe vivo & & \\
\hline
\end{tabular}

Quantos fornecedores a empresa possui? 
Como é a relação com os produtores de peixe?

(__ integração vertical ( produz alevinos, ração, medicamentos, etc e fornece aos produtores, mediante contrato)

(_ ( ) $1 / 2$ integração (fornece assistência técnica, e compra de terceiros a ração e os alevinos que fornece aos produtores, mediante contrato)

(_ ) via mercado (compete com pesque-pagues e outras indústrias na hora de comprar o peixe vivo)

Haveria vantagem de uma integração vertical (piscicultor-frigorífico) ?

$(\ldots) \operatorname{sim}$

(_) não

Qual o critério para pagar o fornecedor de matéria-prima?

(__ porcentagem de filé

(_) peso bruto

(_) livre negociação

(_ ) distância da propriedade

(__ quantidade mínima despescada

(_) tamanho do peixe

Fornece assistência técnica aos fornecedores de matéria-prima?

(_) $\operatorname{sim} \quad(\ldots)$ cobrada $\quad(\ldots$ ) gratuita

Quem é responsável pelo serviço de despesca?

(_) a empresa (_) o produtor

$(\ldots)$ terceiros

Quanto custa em média o quilômetro rodado?

Mão de obra empregada pela empresas:

\begin{tabular}{|l|l|l|}
\hline & \multicolumn{2}{|c|}{ Número } \\
\hline Despesca & & \\
\hline Abate & & \\
\hline Filetagem & & \\
\hline $\begin{array}{l}\text { Aproveitamento de } \\
\text { resíduos }\end{array}$ & & \\
\hline Embalagem & & \\
\hline Administração & & \\
\hline Vendas & & \\
\hline Assistência técnica & & \\
\hline Compras & & \\
\hline Motorista & & \\
\hline Outros & & \\
\hline Total & & \\
\hline
\end{tabular}


Quantas toneladas dias de filé de tilápia sua empresa poderia produzir e estocar se usasse toda a sua capacidade instalada de produção?

Indique no quadro abaixo a quantidade total $(\mathrm{kg})$ dos principais produtos elaborados por sua empresa e seus respectivos preços médio de venda, se possível nos últimos cinco anos.

\begin{tabular}{|c|c|c|c|}
\hline & 1998 & 1999 & 2000 \\
\hline \multirow[t]{2}{*}{ Filé de tilápia } & $\mathrm{Kg}$ & $\mathrm{Kg}$ & $\mathrm{Kg}$ \\
\hline & $\mathrm{R} \$ / \mathrm{kg}$ & $\mathrm{R} \$ / \mathrm{kg}$ & $\mathrm{R} \$ / \mathrm{kg}$ \\
\hline \multirow[t]{2}{*}{ Pestisco } & $\mathrm{Kg}$ & $\mathrm{Kg}$ & $\mathrm{Kg}$ \\
\hline & $\mathrm{R} \$ / \mathrm{kg}$ & $\mathrm{R} \$ / \mathrm{kg}$ & $\mathrm{R} \$ \mathrm{~kg}$ \\
\hline \multirow[t]{2}{*}{ Pele } & $\mathrm{Kg}$ & $\mathrm{Kg}$ & $\mathrm{Kg}$ \\
\hline & $\mathrm{R} \$ / \mathrm{kg}$ & $\mathrm{R} \$ / \mathrm{kg}$ & $\mathrm{R} \$ / \mathrm{kg}$ \\
\hline \multirow[t]{2}{*}{ Farinha de peixe } & $\mathrm{Kg}$ & $\mathrm{Kg}$ & $\mathrm{Kg}$ \\
\hline & $\mathrm{R} \$ / \mathrm{kg}$ & $\mathrm{R} \$ / \mathrm{kg}$ & $\mathrm{R} \$ / \mathrm{kg}$ \\
\hline \multirow[t]{2}{*}{ Outros } & $\mathrm{Kg}$ & $\mathrm{Kg}$ & $\mathrm{Kg}$ \\
\hline & $\mathrm{R} \$ / \mathrm{kg}$ & $\mathrm{R} \$ / \mathrm{kg}$ & $\mathrm{R} \$ / \mathrm{kg}$ \\
\hline
\end{tabular}

Indique no quadro abaixo as porcentagens da produção que você comercializa junto aos seguintes canais de comercialização:

\begin{tabular}{|l|l|}
\hline \multicolumn{1}{|c|}{ Canal de comercialização } & \\
\hline Escolas & \\
\hline Hotéis & \\
\hline Supermercados & \\
\hline Padarias & \\
\hline Restaurantes e Lanchonetes & \\
\hline Feiras livres & \\
\hline Pesque-pagues & \\
\hline Distribuidores & \\
\hline Direto aos consumidores finais & \\
\hline Outros & \\
\hline Total & \\
\hline
\end{tabular}

Indique o número de compradores que sua empresa possui para os seguintes produtos:

\begin{tabular}{|l|c|c|c|c|c|}
\hline & $\begin{array}{c}\text { Filé de } \\
\text { tilápia }\end{array}$ & Pele de tilápia & $\begin{array}{c}\text { Farinha de } \\
\text { peixe }\end{array}$ & Petisco & Outros \\
\hline $\begin{array}{l}\text { Número de } \\
\text { compradores }\end{array}$ & & & & & \\
\hline
\end{tabular}

Existe perspectivas de diversificação da linha de produção da empresas
( ) não
Quais? 
Marque com um X a forma pela qual são formados os preços dos produtos elaborados:

\begin{tabular}{|l|l|l|l|l|l|}
\hline $\begin{array}{l}\text { Forma de } \begin{array}{l}\text { Fixação de } \\
\text { preços }\end{array} \\
\text { Empresa fixa } \\
\text { to preçópias }\end{array}$ & $\begin{array}{l}\text { Pele de } \\
\text { tilápias }\end{array}$ & Petisco & $\begin{array}{c}\text { Farinha de } \\
\text { Peixe }\end{array}$ & Outros \\
\hline $\begin{array}{l}\text { Comprador } \\
\text { fixa o preço }\end{array}$ & & & & & \\
\hline $\begin{array}{l}\text { Empresa } \\
\text { segue o } \\
\text { preço do } \\
\text { mercado }\end{array}$ & & & & & \\
\hline $\begin{array}{l}\text { Comprador e } \\
\text { empresa } \\
\text { negociam o } \\
\text { preço }\end{array}$ & & & & & \\
\hline
\end{tabular}

Dê notas de 0 a 10 para os itens considerados como empecilhos à entrada de novas empresas no mercado (Dê a nota maior ao maior empecilho)

\begin{tabular}{|l|l|}
\hline \multicolumn{1}{|c|}{ Empecilho } & Nota \\
\hline Valor do investimento inicial & \\
\hline Acesso à tecnologia & \\
\hline Acesso à matéria-prima & \\
\hline Custo do capital de giro & \\
\hline Regulamentação estatal & \\
\hline Escala mínima da planta & \\
\hline Contratos de fornecimento & \\
\hline Necessidade de integração vertical & \\
\hline Capacidade ociosa das empresas instaladas & \\
\hline Dificuldade para comercializar o produto & \\
\hline Concorrência no mercado de peixe vivo & \\
\hline Outros & \\
\hline
\end{tabular}

Indique com um $X$ se sua empresa possui nenhuma, pouca, média ou bastante informação sobre o preço e o volume de produção dos concorrentes:

\begin{tabular}{|l|l|l|l|l|}
\hline & Nenhuma & Pouca & Média & Bastante \\
\hline Filé de tilápia & & & & \\
\hline Outros & & & & \\
\hline
\end{tabular}


Estratégias da Empresa em relação à concorrência:

\begin{tabular}{|l|l|}
\hline Nenhuma & \\
\hline Redução de preços via redução de custos & \\
\hline $\begin{array}{l}\text { Redução de preços via redução de margens } \\
\text { de lucro }\end{array}$ & \\
\hline Melhoria de qualidade do produto & \\
\hline Propaganda da marca (empresa) & \\
\hline Propaganda do produto & \\
\hline Publicidade & \\
\hline
\end{tabular}

Existe algum sistema de garantia de qualidade de filé de tilápia na sua empresa?

(_) nenhum

) controle do tamanho do filé

) controle de sabor e cheiro do filé

(_) testes das propriedades químicas e físicas do filé

(_) inovações no processo de conservação

(_) inovações no processo de produção

(_) inovações na embalagem

(_ treinamento de produtores

(_) treinamento de funcionários ) outros:

Assinale com um $\mathrm{X}$ as principais estratégias de vendas adotadas pela empresa

(_) televendas

) pronta entrega

(_) sob encomenda

(_) vendas terceirizadas

(_) vendas diretas ao consumidor

(_) outras: 